End-Use Load and Consumer Assessment Program

\title{
Measured Electric Hot Water Standby and Demand Loads from Pacific Northwest Homes
}

R. G. Pratt

B. A. Ross

November 1991

Prepared for the Bonneville Power Administration under a Related Services Agreement with the U.S. Department of Energy Contract DE-AC06-; 6RLO 1830

and the Northwest Power Planning Council

Pacific Northwest Laboratory Operated for the U.S. Department of Energy by Battelle Memorial Institute 


\title{
DISCLAIMER
}

This report was prepared as an account of work sponsored by an agency of the United States Government. Neither the United States Government nor any agency thereof, nor Battelle Memorial Institute, nor any of their employees, makes any warranty, expressed or implied, or assumes any legal liability or responsibility for the accuracy, completeness, or usefulness of any information, apparatus, product, or process disclosed, or represents that its use would not infringe privately owned rights. Reference herein to any specific commercial product, process, or service by trade name, trademark, manufacturer, or otherwise does not necessarily constitute or imply its endorsement, recommendation, or favoring by the United States Government or any agency thereof, or Battelle Memorial Institute. The views and opinions of authors expressed herein do not necessarily state or reflect those of the United States Government or any agency thereof.

\author{
PACIFIC NORTHWEST LABORATORY \\ operated by \\ BATTELLE MEMORIAL INSTITUTE \\ for the \\ UNITED STATES DEPARTMENT OF ENERGY \\ under Contract DE-ACO6-76RLO 1830
}

Printed in the United States of America

Available to DOE and DOE contractors from the

Office of Scientific and Technical Information, P.O. Box 62, Oak Ridge, TN 37831; prices available from (615) 576-8401. FTS 626-8401.

Available to the public from the National Technical Information Service, U.S. Department of Commerce, 5285 Port Royal Rd., Springfield, VA 22161. 
PNL- -7889

DE92 004449

End-Use Load and Consumer Assessment Program

MEASURED ELECTRIC HOT WATER STANDBY AND DEMAND LOADS FRON PACIFIC NORTHWEST HOMES

R. G. Pratt

B. A. Ross

November 1991

Prepared for

the Bonneville Power Administration

under a Related Services Agreement

with the U.S. Department of Energy

Contract DE-AC06-76RLO 1830

and the Northwest Power Planning Council

Pacific Northwest Laboratory

Operated for the U.S. Department of Energy

by Battelle Memorial Institute 


\section{ACKNOWLEDGEMENTS}

The analysis documented in this report was jointly conducted for the Bonneville Power Administration, End-Use Research Section, and the Northwest Power Planning Council by the Energy Sciences Department at the Pacific Northwest Laboratory (PNL). The report reflects a team effort involving close collaboration between Bonneville, the Council, and PNL. The authors wish to express their appreciation for the technical guidance and reviews provided by Megan Taylor at Bonneville and Margie Gardner at the Counci1, and editorial review provided by Susan Page-York, a contract editor for Bonneville.

The authors also extend their thanks to other PNL staff who contributed to this report's preparation: Linda Seidel for word processing and Kathleen Hanson for editing the entire report. 


\section{CONTENTS}

Section $\quad$ Page

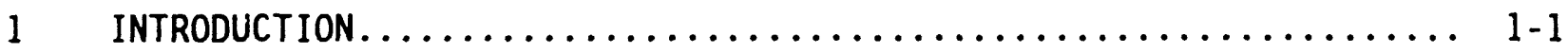

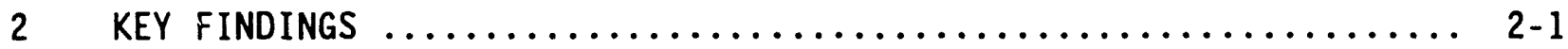

2.1 STANDBY LOADS............................. 2 1

2.1.1 Temperatures and Tank Locations............... 2-2

2.1.2 Tank EF-Factors....................... 2-3

2.1.3 Effective Tank R-Values................... 2-3

2.1.4 Impacts of Conservation Measures............ 2-4

2.1.5 Nominal R-Values...................... 2-4

2.2 DEMAND LOADS........................... 2-5

2.3 SECONDARY FINDINGS $\ldots \ldots \ldots \ldots \ldots \ldots \ldots \ldots \ldots \ldots \ldots \ldots \ldots \ldots \ldots$

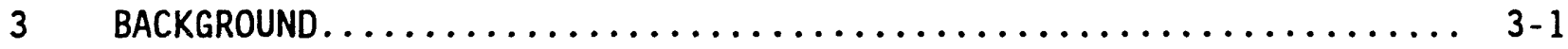

3.1 WATER HEATER CONFIGURATION AND CONSUMPTION........... 3-1

3.1.1 Tank Construction and Control................. 3-1

3.1.2 Hot Water Tank Heat Transfer Processes............ 3-3

3.1.3 Conservation Measures..................... 3-5

3.2 WATER HEATING ENERGY IN THE REgIONAL PLANNING PROCESS ...... 3-7

3.2 .1 Standby Loads....................... 3-7

3.2.2 Demand Loads......................... 3-9

4 ANALYSIS OVERVIEW............................. $4-1$

4.1 ELCAP DATA USED ........................... $4-2$

4.2 SUMMARY OF THE TECHNICAL APPROACH................. 4 -3

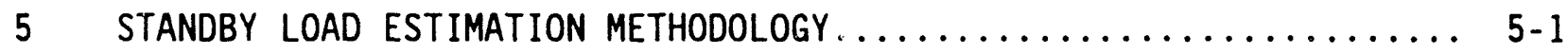

5.1 WARMUP EVENT FILTER......................... $5-1$ 
5.2 STANDBY LOAD ESTIMATION..................... 5-3

5.3 INVESTIGATION OF NON-IDEAL STANDBY EVENT PATTERNS........ 5-6

5.3 .1 Vacancy Setbacks..................... 5-6

5.3.2 Dueling Thermostats.................... 5-9

5.4 VACANCY SETBACK AND DUELING THERMOSTAT DETECTION......... 5-12

5.5 OCCUPIED/UNOCCUPIED CALIBRATION RATIO............. 5-14

5.5.1 Number of Homes Available for Analysis........... 5-15

5.5.2 Use of Trimmed or Untrimmed Means............. 5-15

5.5.3 Determination of the Calibration Ratio............ 5-18

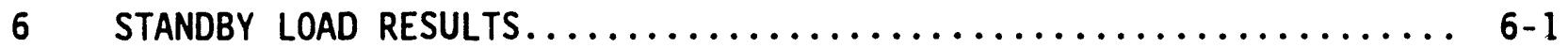

6.1 Average Standby Loads........................ 6-1

6.2 HOT WATER TEMPERATURES AND TANK LOCATION TEMPERATURES ...... $6-3$

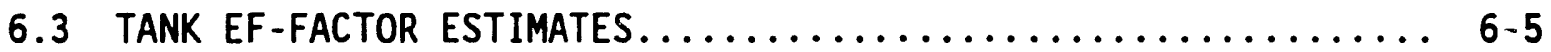

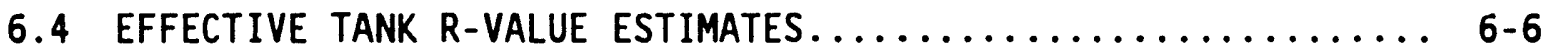

6.5 NOMINAL TANK R-VALUE ESTIMATES.................. $6-8$

6.6 CONSERVATION MEASURE IMPACTS $\ldots \ldots \ldots \ldots \ldots \ldots \ldots \ldots \ldots \ldots \ldots \ldots \ldots \ldots \ldots$

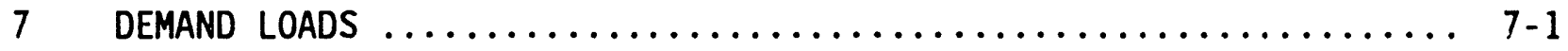

7.1 AVERAGE NUMBER OF OCCUPANTS .................. $7-1$

7.2 MODELS OF TOTAL HOT WATER LOADS ................. 7-5

7.3 MODELS OF HOT WATER DEMAND LOAD ESTIMATES ............. 7-8

8 STANDBY AND DEMAND EFFECTS ON LOAD SHAPE AND SEASONAL

CONSUMPTION .................................... $8-1$

9 REFERENCES ................................. 9.1

Appendix A - OFFSET DRIFT ADJUSTMENTS .................. A-1

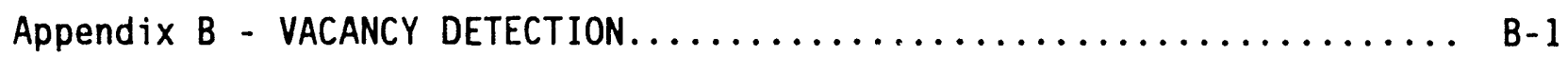

Appendix $C$ - TANK LOCATION AIR TEMPERATURE ESTIMATION ........... C-I

Appendix D - THERMAL SIMULATION OF STANDBY EVENTS IN HOT WATER TANKS... D-1 
Appendix E - EFFECTS OF VACANCY SETBACKS AND DUELING THERMOSTATS ON STANDBY LOAD ESTIMATES ....................... E-1

Appendix $F$ - ADDITIONAL STANDBY RESULTS $\ldots \ldots \ldots \ldots \ldots \ldots \ldots \ldots \ldots \ldots \ldots$

Appendix G - MANUFACTURERS' DATA ON HOT WATER TANKS ............ G-1

Appendix $H$ - CONSERVATION MEASURE IMPACTS DERIVED FROM THE BONNEVILLE TEST DATA OF EK AND AUBERG (1984) $\ldots \ldots \ldots \ldots \ldots \ldots \ldots \ldots \ldots, \mathrm{H}-\mathrm{l}$ 


\section{FIGURES}

Figure $\quad$ Page

3-1 Typical Hot Water Heater...................... 3-2

3-2 Typical Warmup Events in Standby Mode............... 3-5

4-1 Typical Hot Water Load - Two Occupied Days.............. 4-4

4-2 Typical Hot Water Load - Two Vacant Days............... 4-5

4-3 Typical Energy - Interval Diagram................. 4-6

4-4 Typical Handwashing Warmup Event................... 4-8

5-1 Typical Fenergy-Interval Diagram - Vacancy Setback......... 5-7

5-2 Typical Hot Water Loads - Vacancy Setback............... 5-8

5-3 Typical Energy-Interval Diagram - - Dueling Thermostats...... 5-9

5-4 Typical Hot Water Loads -. Dueling Thermostats........... 5-10

5-5 Simulation of Tank with Dueling Thermostats........... 5-11

5-6 Calibration Ratio as a Function of Setback Frequency Criteria.................................... 5-18

5-7 Number of Sites Passing Setback Frequency Criteria ....... 5-19

5-8 Calibration Ratio as a Function of Dueling and Setback Frequency Criteria................ 5-20

5-9 Number of Sites Passing Setback and Dueling Criteria...... 5-21

7-1 Total Hot Water Load by Number of 0ccupants........... 7-5

8-1 Average Total Hot Water and Standby

Monthiy Loads for the Base Study..................... 8-1

8-2 Average Total Hot Water and Standby Load Profiles for the Base Study................... 8-2 


\section{TABLES}

Table

5-1 Mean Standby Loads and the Calibration Ratio

for the Homes in the ELCAP Sample................. 5-16

5-2 Standby Estimates and Calibration Ratios for

ELCAP Homes in the Analysis....................... 5-17

5-3 Summary of Results: Standby Estimates and Calibration Ratios for ELCAP Homes in the Analysis.................. 5-22

6-1 Calibration and Extrapolated Standby Estimates........... 6-2

6-2 Mean Hot Water and Normal Tank Location Temperatures....... 6-4

6-3 Tank EF-Factor Estimates....................... 6-7

6-4 Effective R-Value Estimates.................... 6-8

6-5 Nominal R-Value Estimates..................... 6-9

6-6 Conservation Measure Variables Used as

Explanatory Variables in Standby Load Models............ 6-11

6-7 Regression Model Results..................... 6-13

7-1 ELCAP Hot Water Loads per Occupant All Studies........... 7-2

7-2 ELCAP Hot Water Loads per Occupant A11 Studies for the Base Study................................ 7-2

7-3 ELCAP Hot Water Demand Loads per Occupant All Studies...... 7-3

7-4 ELCAP Hot Water Demand Loads per Occupant for the Base Study............................... 7-3

7-5 Regression Models of Total Hot Water Loads........... 7-6

7-6 Regression Models of Hot Water Demand Loads........... 7-8 


\subsection{INTRODUCTION}

The Bonneville Power Administration (Bonneville) began the End-Use Load and Consumer Assessment Program (ELCAP) in 1983 to obtain metered hourly end-use consumption data for a large sample of new and existing residential and commercial buildings in the Pacific Northwest. Currently, metering of a portion of the ELCAP sample is continuing under the auspices of the new Residential End-Use Metering Project (REMP). Loads and load shapes from the first 3 years of data for each of several ELCAP residential studies representing various segments of the housing population have been summarized by Pratt et a1. (1989). The analysis reported here uses the ELCAP data to investigate in much greater detail the relationship of key occupant and tank characteristics to the consumption of electricity for water heating.

In the largest of the ELCAP studies, the Base Study of existing (as of 1983) single-family homes with permanent electric space heating equipment, consumption of electricity to heat water for 207 residences averaged about $4600 \mathrm{kWh} / \mathrm{yr}$, slightly over half that used for space heat and $22 \%$ of the total electricity consumed (Pratt et.al. 1989). (a) Further, consumption for water heating rises $13 \%$ above the annual average in the months of December and January. Consumption data also indicate a strong morning peak in the hours between 8 and 10 a.m. and a secondary peak in the evening hours between 6 and 10 p.m. Thus, peak water heating loads coincide with regional system peak demands in the Northwest (and also to a lesser extent with the evening system peaks exhibited elsewhere in the United States).

Clearly, residential water heating is a critical element in load forecasting of future regional energy consumption and regional and local peak demands. Energy forecasts assume that water heating loads will decrease as existing water heaters are gradually replaced with new models that comply with

(a) A more recent study by Taylor et al. (1991) on 5-years of ELCAP data indicates the consumption of electricity to heat water averages about 4762 kWh. The difference (3\%) in this number and the one by Pratt et al. (1989) is the increase in amount of data and change in number of occupants in sites participating in the study. 
1990 federal appliance standards (Bonneville Power Administration 1990). The 1990 standards for water heaters require lower standby heat losses (standby heat is that required to make up for losses from the tank when no hot water is being used, i.e., when the demand is zero), typically achieved in electric tanks by higher insulation levels. Further, it has been estimated that 460 average megawatts (AMW) of additional conservation resource in a high demand forecast can be achieved by the year 2010 through more extensive conservation measures. These measures include even higher levels of insulation, a device that returns hot water in the pipes to the tank after each hot water draw, and reductions in water demand through energy-efficient showerheads, clotheswashers and dishwashers. An additional 190 AMW of conservation could be achievable in the high demand forecast if heat pump water heaters with heat recovery ventilation were installed in new households that have high water demands. These additional savings are calculated after the other more costeffective measures are already installed (Northwest Power Planning Council 1991, Power Plan, Vol 2, Chapter 7).

The hourly data collected provides opportunities to understand electricity consumption for heating water and to examine assumptions about water heating that are critical to load forecasting and conservation resource assessments.

Specific objectives of this analysis are to

- determine the current baseline for standby heat losses by determining the standby heat loss of each hot water tank in the sample

- examine key assumptions affecting standby heat losses such as hot water temperatures and tank sizes and locations

- estimate, where possible, impacts on standby heat losses by conservation measures such as insulating tank wraps, pipe wraps, anticonvection valves or traps, and insulating bottom boards

- estimate the EF-factors ${ }^{(a)}$ used by the federal efficiency standards and the nominal $R$-values of the tanks in the sample

(a) EF-factor is a standard measure of efficiency defined in federal appliance efficiency standards (Federal Register 1977). 
- develop estimates of demand for hot water for each home in the sample by subtracting the standby load from the total hot water load

- examine the relationship between the ages and number of occupants and the hot water demand

- place the standby and demand components of water heating electricity consumption in perspective with the total hot water load and load shape.

Section 2 of this report summarizes key findings of the analysis. Section 3 provides background for the analysis in terms of how water heaters are constructed and controlled and how their consumntion and conservation potential are analyzed for regional power planning purposes. Section 4 presents an overview of the analysis -- the data and the methods used. Section 5 describes the techniques used for estimating standby loads in individual homes and discusses sources of bias and error in the analysis (more detailed discussions of specific issues regarding the methodology are found in the appendices). Sections 6 and 7 present the results of the analys is of the standby and demand loads, respectively. A brief overview of the relationship of the standby and demand loads to the total hot water loads is included in Section 8. Appendix A describes offset drift adjustments; Appendix $B$ discusses vacancy detection; Appendix $C$ describes tank location air temperature estimation; Appendix $D$ discusses thermal simulation of standby events in hot water tanks; Appendix $E$ describes effects of vacancy setbacks and dueling thermostats on standby load estimates; Appendix F presencs additional standby results; Appendix G gives manufacturers' data on hot water tanks; Appendix $H$ describes impacts of conservation measures derived from Bonneville test data of EK and Auberg 1984. 


\subsection{KEY FINDINGS}

This section summarizes key findings from analyzing the relationship between key occupant and hot water tank characteristics and the consumption of electricity for water heating. The key findings are divided into three topic areas: standby loads, demand loads, and other secondary findings regarding methodology or hot water tank operation.

\subsection{STANDBY LOADS}

The primary objective of the analysis is obtaining an estimate of the average standby load (heat losses) of the current population of electric hot water tanks. The average standby load is an important element of the residential furecast, because much of the reduction in water heating energy consumption in the future is the difference between the current loads and those projected to result from tank efficiency standards and conservation programs. Standby loads were estimated for the three groups of ELCAP homes: 1) Base Study homes (all single family, detached, owner-occupied with electric space heating equinment) for the ELCAP, 2) Residential Standards Demonstration Program (RSDP) study homes (all constructed in 1983-1984 as part of the RSDP, and 3) all ocher homes in ELCAP. A11 homes analyzed have a single active electric hot water heater. The results of this analysis are:

- The average standby load for the ELCAP Base Study homes is about 1200 kWh/yr, about the same as the 1991 estimate by the Northwest Power Planning Council for the current population of existing tanks (1700 kwh/yr).

- The average standby load in the RSDP study homes is about $1100 \mathrm{kWh} / \mathrm{yr}$, less tnan the for the Base Study.

- The Base Study homes have wore water heating conservation measures installed than indicated in the regional average for similar home'. In ELCAP homes, $41 \%$ of the water heaters are wrapped, $9 \%$ have bottom boards, and $2 \%$ have thermal traps. 


\subsubsection{Temperatures and Tank Locations}

Because, in theory, standby loads are proportional to temperature differences between hot water in the tanks and air surrounding the tanks, differences in the planning assumptions and in estimates for ELCAP homes could explain variances in standby load estimates.

Section 6 of this report discusses hot water temperatures and tank location temperatures, broken down by ELCAP study. Principal findings are as follows:

- Hot water tap temperatures average $137^{\circ} \mathrm{F}$ for all ELCAP homes. The averages are $138^{\circ} \mathrm{F}$ for the Base Study and $131^{\circ} \mathrm{F}$ for the RSDP study homes, and even higher for other ELCAP homes -- $140 \circ \mathrm{F}$.

- The most common tank locations for the Base Study homes, as indicated by the sample size for the tank locations, are 34\% in primary occupied spaces, $27 \%$ in heated and daylight basements, and $15 \%$ in both unheated basements and garages.

- If used as an indicator of current construction trends, the RSDP study homes have very few unheated basements. The hot water tanks in unheated basements in the Base Study homes appear to have been installed mainly in heated spaces in the RSDP study howes, raising the fraction of tanks in primary occupied zones to $48 \%$.

Air teinperatures surrounding the tanks were estimated, not measured (except for occupied spaces). Nevertheless, they should reasonably approximate the actual air temperatures at the tank locations.

- For the Base Study homes, the average air temperature surrounding the tank averages $62^{\circ} \mathrm{F}$, ranging from $70^{\circ} \mathrm{F}$ in the heated spaces to $52^{\circ} \mathrm{F}$ for one tank located outdoors. The overall average for the RSDP study is nigher, $65^{\circ} \mathrm{F}$, because of the shift in tank locations toward heated spaces. 
- Thus, heat losses that cause standby loads are driven by temperature differences of about $76^{\circ} \mathrm{F}$ in the Base Study, $66^{\circ} \mathrm{F}$ in the RSDP study, and $7^{\circ} \mathrm{F}$ for all ELCAP homes. The lower temperature difference may explain lower standby loads in the RSDP hows.

- The average temperature difference used in the regional planning estimate is $70 \circ \mathrm{F}$. This suggests the ELCAP Base Study standby Toads should be $10 \%$ higher than the regional estimates, all other factors being equal. Thus, temperature differences do not explain why planning estimates are lower.

\subsubsection{Tank EF-Factors}

Tank EF-factors are a measure of hot water tank heat loss developed for the federal appliance efficiency standards and used to project future impact of those standards. The EF-factors estimated here include efficiency increases resulting from any installed conservation measures.

- An average tank EF-factor of 0.79 was estimated for tanks in the Base Study and for all ELCAP howes.

- An average tank EF-factor of 0.78 was estinated for the RSDP study. This suggests that these hot water tanks, purchased in 1983, have heat loss rates as high as those in the Base Study.

\subsubsection{Effective Tank R-Values}

The effective tank R-value is the insulation R-value that, if uniformly applied to the actual tank surface area, would produce standby loads equal to those reported, given observed temperature differences. Thus, the effective R-value adjusts for differences in tank size.

- The average effective tank R-values for the Base Study homes are about R-4.4. 
- The RSDP study average is slightly lower, about R-4.0. The lower EFfactors of the RSDP study tanks (EF of 0.78 ) compared to the Base Study tanks (EF of 0.79 ) result from lower insulation levels, not from larger tanks.

\subsubsection{Impacts of Conservation Measures}

To determine impacts of conservation measures, a series of regression models were used to compare standby load estimates for sites with and without conservation measures to reduce standby loads.

- A model of heat loss coefficients produced savings estimates for tank wraps and botton boards. The results confirm laboratory tests conducted by Ek and Auberg (1984), if the value of tank wraps is discounted to reflect a sizeable fraction of wraps only partially covering the tank. The value for the bottom boards is remarkably close to the laboratory test results.

\subsubsection{Nominal R-Values}

Nominal $R$-values approximate $R$-values reported in manufacturers' literature (i.e., the R-value of the tank wall insulation). Estimated nominal $R$-values account for the effects of reduced average insulation thickness on tank bottoms and tops, heat losses from pipes and fittings, and standby load conservation measures such as tank wraps, bottom boards, thermal traps and pipe insulation. Adjustments for these effects were made on the basis of physical measurements of tanks, manufacturer reported R-values, efficiency testing data on numerous tanks, and laboratory test results for efficiency measure impacts.

- Nominal R-values for the tanks in the Base Study are R-8.8, considerably higher than the nominal $R-5$ tanks assumed as the current baseline in the regional planning process. For the RSDP study, the nominal R-value was R-7.5. 


\subsection{DEMAND LOADS}

Demand loads resulting from occupant use of hot water were estimated as the difference between total loads and standby load estimates. Several models of demand loads were constructed as a function of occupant number and age in the ELCAP homes. Results of this analysis are as follows.

- A linear model of demand loads as a function of occupant number, applied to a typical home with 2.5 occupants, suggests the average demand load per occupant is about $1190 \mathrm{k} / \mathrm{h} / \mathrm{yr}$.

- Using the Northwest Power Planning Council's assumption of an $80^{\circ} \mathrm{F}$ temperature difference between the cold inlet water and the hot water, this average demand load is equivalent to a consumption rate of 17 gallons/day-occupant, very close to the regional planning assumption of 18.6 gallons/day and is a longstanding rule of thumb of 20 gallons/day.

- The statistically significant intercept for the linear model (911 $\mathrm{kw} / \mathrm{hr}$ ) suggests that hot water demand is nonlinear with number of occupants.

- A model of consumption per occupant by age group suggests a demand load of $2133 \mathrm{kWh} / \mathrm{yr}$ for the head of the household (18 through 65 years), while additional adults add $765 \mathrm{kWh} / \mathrm{yr}$ to consumption. This implies that there is a residual demand for hot water in homes (perhaps for clothes and dishwashing) independent of the number of occupants.

- The age group model also suggests occupants under 6 years and over 65 years use much less hot water $(323 \mathrm{kWh} / \mathrm{yr}$ ) than occupants of other age groups. Children 6 through 17 appear to consume 15\% more hot water on average than adults 18 through 65. Along with the residual household demand 1,rad, this may account for the observed nonlinear activities.

The $y$-axis intercepts of linear models of metered total (standby and demand) water heating loads were used previously to estimate standby loads for 
regional planning estimates. The intercept is an estimate of the hot water load for zero occupants, and so by definition should be equal to the standby load.

- Using a linear model, the $y$-axis intercept of total water heating loads produced a standby estimate $1917 \mathrm{kWh} / \mathrm{yr}$ for ELCAP homes. That estimate is much higher than standby loads estimated in this analysis, presumabiy because the linear model does not properly account for residual household demand and occupant age effects. As a result, both previous standby and dewand load estimates obtained using the linear model technique are probably not accurate.

Demand loads were compared with total water heating and standby loads to develop the following observations.

- Demand loads account for about two-thirds of the average total household hot water consumption and for nearly all variation in load during the day and year.

- Because most water heating conservation measures and standards impact standby loads more than demand loads, the seasonal variation of residential water heating loads in the future is likely to increase (in percentage terms) as conservation measures redur.e standby loads. This may be important to planners involved in intraregional power sales.

- Reducing standby loads will also result in lower peak loads, but the hot water end-use load shape will also get "peakier" (have a lower load factor). This may become important to utility systems that experience significant variations in costs for generating power during peak and off-peak periods. 


\subsection{SECONDARY FINDINGS}

- Vacancy periods can be detected and used to estimate standby loads for individual water heaters.

- Standby loads can also be estimated by carefully filtering time series data so that only standby loads remain. A calibration factor correcting for the remaining demand loads has been developed.

- The average load between 4 a.m. and 5 a.m. is almost equal to the standby load estimate obtained by analyzing the time series data from individual homes. This is additional evidence supporting the standby estimates obtained here, and suggests a simple alturnative methodology for estimating standby loads from average load shapes for groups of buildings, and perhaps for individual buildings as well.

- A significant number of occupants turn their water heater thermostats down during extended vacancies. Many others turn them completely off at the breaker panel.

- A significant number of water heaters exhibit semichaotic patterns of standby loads during vacancies. A simple thermal simulation of a hot water tank was constructed and used to demonstrate that identical patterns of loads can occur when the lower heating element has a thermostat setting that is only slightly higher than that of the upper heating element.

- Federal efficiency standards tests to determine EF-factors appear unreliable when the factors are about 0.92 or greater because the 48-hour test used produces only a few ( 3 to 5 ) cycles for tanks that are this efficient. The arbitrary termination of the test in the middle of the last cycle produces a bias toward lower average standby loads (by factors up to one-fifth or one-third) and hence artificially high EFfactors. Thus, EF-factors derived from the current testing procedure 
may prove unreliable for resource planning purposes as tank efficiencies approach higner levels.

- Careful review of the test results of Ek and Auberg (1984) suggests that two of the tests produced all the largest outliers in their conservation measure impact estimates. Eliminating the results of these two tests cleared up the puzzling implication by the data that pipe heat loss reducing measures interact with tank heat loss reducing measures. 


\subsection{BACKGROUND}

This section of the report provides some background and context for the analysis of ELCAP hot water loads. The section is divided into two parts. Section 3.1 describes how water heaters work and the conservation measures that can be applied to save energy. Section 3.2 summarizes how energy consumption for water heating is analyzed in the regional forecasting/supply curve planning process and includes key assumptions and data sources from which planning estimates are derived.

\subsection{WATER HEATER CONFIGURATION AND CONSUMPTION}

This section is further divided into three subtopics. The first describes how water heaters are typically constructed and controlled. The next briefly presents the basic thermal processes governing energy consumption for water heating. The third subtopic presents an overview of the conservation measures that can be applied to save water heating energy.

\subsubsection{Tank Construction and Control}

A schematic of a typical electric residential hot water heater is shown in Figure 3-1. The tank itself is usually cylindrical, about three times taller than its diameter, with a slightly convex (as opposed to flat) top and a similarly concave bottom. Its volume is equal to that of a right circular cylinder, although because of the curvature of the ends, its surface area is slightly larger (this small difference is ignored in this analysis). The tank itself is usually steel and is surrounded by either fiberglass or foam insulation contained within a metal jacket. If fiberglass insulation is used on the bottom of the tank, it may be crushed by the weight of the tank when it is full of water; the same is not true of foam insulation (Ek and Auberg 1984). 
Figure 3-1

Typical Hot Water Heater

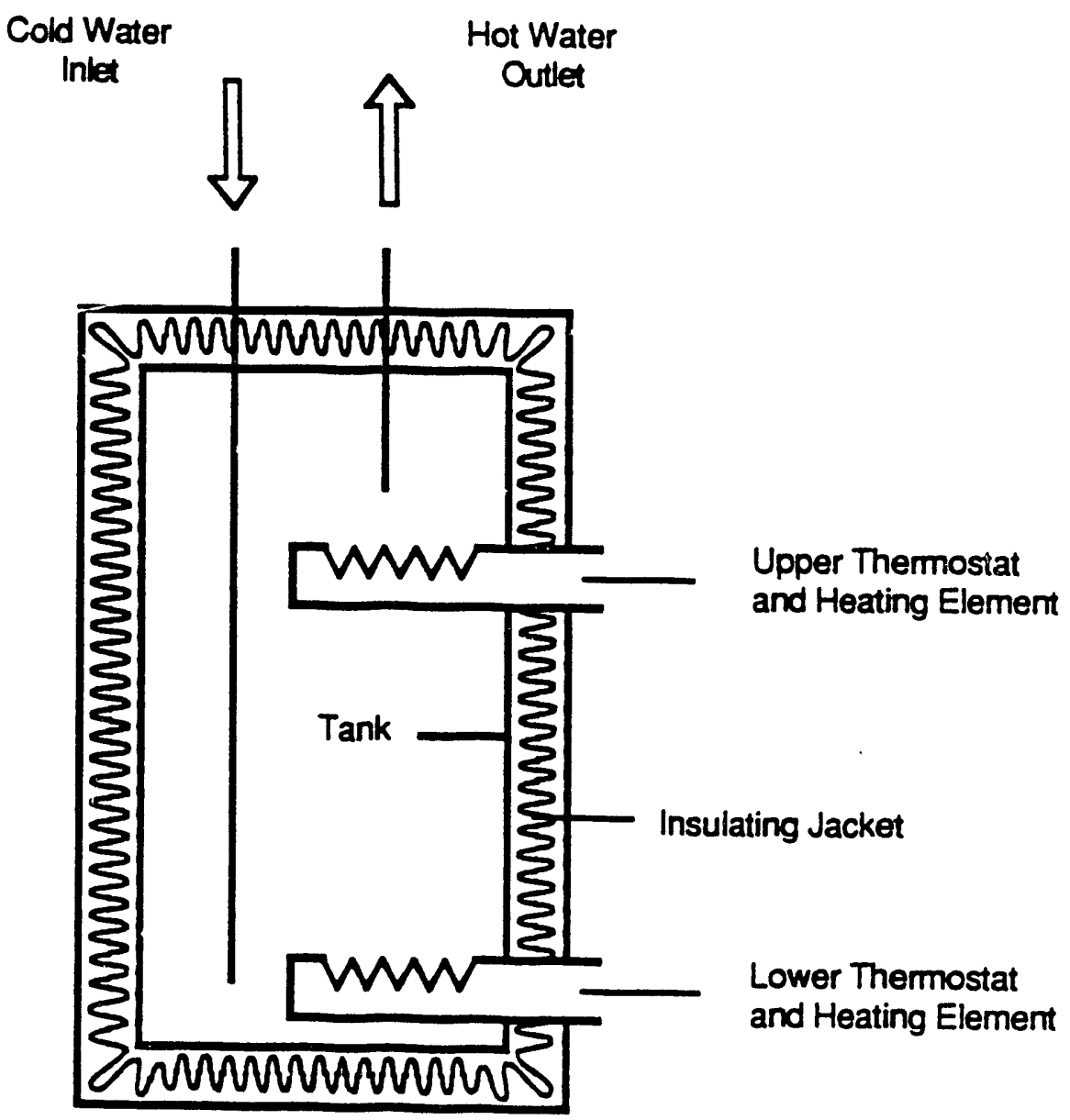

The nominal thickness of the insulation is the distance between the jacket and the inside of the tank.

The water temperature is maintained at the desired hot water tap temperature by one or two electric resistance heating elements and thermostats. One element is always near the bottom of the tank, as the heat it gives off tends to rise through the water. A second upper element is often located one-half to one-third the height of the tank from the top. The upper element, if present, is interlocked with the lower element so it has precedence over the lower element; only one element can draw power at any given time. 
The purpose of the upper element is to maintain at least part of the water in the tank at the set point. It serves this function by heating a smaller quantity of water (only that above the element). The power of both elements is the same, but the upper elenient heats this smaller quantity of water to the set point faster than the bottom element heats the entire tank to the same temperature. Thus, some completely heated water is available to the home even before the entire tank has recovered from previously withdrawn hot water.

\subsubsection{Hot Water Tank Heat Transfer Processes}

There are two basic reasons water heaters consume energy. The largest and most fundamental mode of energy consumption is often termed demand. When hot water is demanded by the occupants who turn on a tap or a hot-water using appliance, the hot water withdrawn from the top of the tank is replaced by cold water from the local water supply (a municipal or civic water district or the home's well). The cold water enters via a cold water inlet pipe extending nearly to the bottom of the tank, as shown in Figure 3-1. The entering cold water mixes to some extent with the already hot water in the tank, but because of its low temperature tends to settle near the bottom. As soon as enough cold water enters the tank to trigger the lower thermostat, the lower heating element begins to heat the water. If enough hot water is withdrawn so the cold water triggers the upper thermostat, the lower element is turned off and the upper element heats only the water above it.

The heat required to supply the demanded hot water is simply that required to heat the replacement cold water to the set point. This is simply described using the equation for sensible heat

$$
Q_{\text {demand }}=\rho C_{p} V_{\text {demand }}\left(T_{\text {hot }}-T_{\text {cold }}\right)
$$

where $Q_{\text {denand }}$ is the heat required, $p$ is the density of water $\left(61.71 \mathrm{bm} / \mathrm{ft}^{3}\right)$, $C_{p}$ is the specific heat of water $\left(1 \mathrm{Btu} / 1 \mathrm{bm}-{ }^{\circ} \mathrm{F}\right), V_{\text {demand }}$ is the volume of hot water withdrawn (in $\mathrm{ft}^{3} ; 1 \mathrm{ft}^{3}$ is 7.48 gallons), and $T_{\text {hot }}$ and $T_{\text {cold }}$ are the hot water set point and cold water tap temperatures $\left({ }^{\circ} \mathrm{F}\right)$, respectively. Note that 
the demand load is proportional to the volume of water consumed and the temperature difference between the hot and cold water.

The second, less obvious mode of energy consumption by hot water heaters is commonly termed standby. When no hot water is demanded by the occupants, the tank slowly cools because it is not perfectly insulated. This heat loss to surroundings is termed the standby loss, $Q_{\text {standby }}$, and is governed by a simple equation of conductive heat loss similar to that for the envelope of a house

$$
Q_{\text {standby }}=U A\left(T_{\text {hot }}-T_{\text {local }}\right)
$$

where $T_{\text {local }}$ is the temperature of the air surrounding the tank $\left({ }^{\circ} F\right)$; UA is the heat loss coefficient of the tank $\left(B t u / h r-{ }^{\circ} \mathrm{F}\right)$ and is equal to the product of the effective $U$-value of the insulation (the reciprocal of the effective R-value) and the tank surface area. Heat losses (i.e., standby losses) can be thought of as "overhead" - - a penalty the user pays to have hot water upon demand, above and beyond that required to heat the water demanded. Thus, standby loss is proportional to the area of the tank and the temperature difference between the hot water and the air where the tank is located and is inversely proportional to the effective R-value of the tank.

The standby mode tends to produce regular periodic pulses of energy consumption, as illustrated in Figure 3-2. As the tank temperature slowly drops to the hot water set point, in this example $130^{\circ} \mathrm{F}$, it finally triggers the tank thermostat and the heating element begins to reheat the water to some temperature slightly above the set point (termed the deadband of the thermostat, typically 4 to $6^{\circ} \mathrm{F}$ ), in this example $134^{\circ} \mathrm{F}$. During the rapid warmup events that follow, the heating element draws current at close to its rated power, usualiy 4500 watts, until the thermostat is satisfied. The tank then begins to cool again and the cycle is repeated. 
Figure 3-2

Typical Warmup Events in Standby Mode

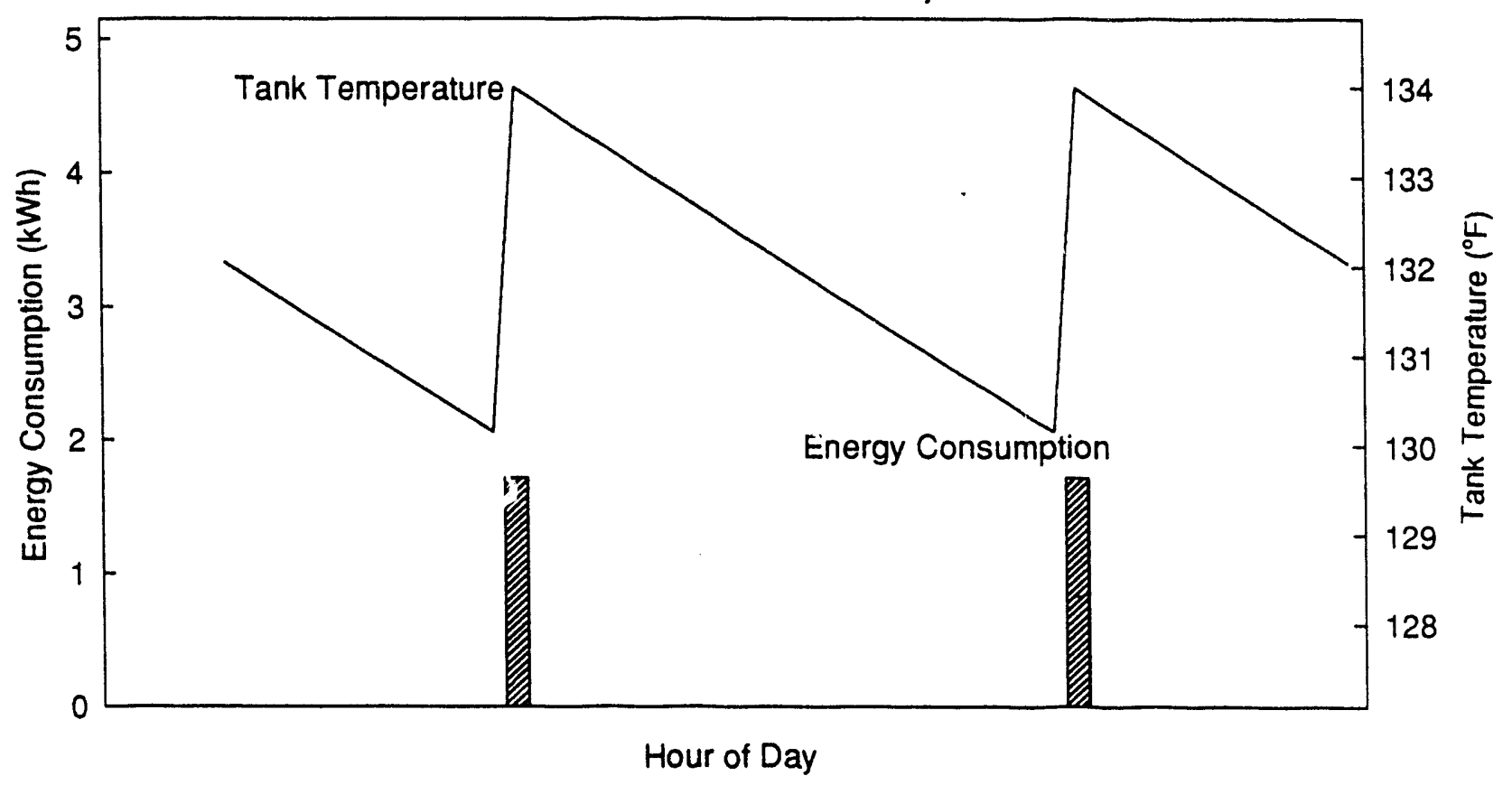

\subsubsection{Conservation Measures}

Conservation measures for water heating can be classified by the mode of consumption they are designed to affect. Only a few technologies impact both supply and demand modes of consumption; these technologies are related to the energy conversion mechanisms used. Examples are heat pump water heaters, solar collectors, and improved combustion efficiencies for fuel-fired water heaters.

There are fundamentally only two types of measures designed to reduce hot water demand loads. The most common measure uses low-flow showerheads and appliances. Because showers are generally regulated by the time spent bathing (as opposed to baths, which require a tub to be filled), reducing the flow of water while still producing an acceptable spray is a well-established conservation measure. Reducing flow rates at faucets tends to be less effective, because often a given quantity of hot water is required (a sinkfull for dishes, a bucket-full for cleaning, etc.). Similarly, clothes 
washers that have warm and cold water settings and small load settings, and horizontal washers where less water is needed to cover the clothes, use less hot water. More sophisticated technologies (high-pressure sprays for dishwashers, for examplej may ultimately have even larger impacts.

The second type of demand-reducing measure is simply to reduce the hot water temperature. This reduces the energy consumed for heating the water demanded by constant volume applications such as dishwashers and clothes washers, although their cleaning and sterilizing performance may be adversely affected by using lower temperatures. Energy consumed for applications driven by demand for a given volume and temperature of hot water, such as baths and showers, remains unaffected by such a reduction.

A number of conservation measures apply to standby heat losses. Clearly, reducing the hot water temperature saves standby energy. Better insulation around the tank, either placed by the manufacturer or subsequently added using a water heater wrap (usually 3 inches of fiberglass that provides a nominal $\mathrm{R}-11$ ० $\mathrm{F}-\mathrm{ft}^{2}-\mathrm{hr} /$ Btu increase in insulation), reduces heat loss. Similarly, setting the tank on a board of insulating foam reduces heat loss through the bottom of the tank and is particularly effective when the standard insulation under the tank is fiberglass, which is easily crushed by the weight of the tank.

Considerable heat is also lost from the uninsulated hot and cold water pipes, which provide highly conductive paths for heat to flow from the tank to the surrounding air. Insulating the pipes for several feet reduces these losses. The hot water in the tank also tends to rise up into these pipes and is replaced by sinking water cooled in them. This convective heat loss greatly enhances the heat flow path provided by the pipes. Thermal traps are a common conservation measure generally consisting of small valves between the tank and the piping, thus, reducing this mode of heat loss. Savings from pipe insulation and thermal traps in combination are less than savings from each measure individually, because both measures reduce the same mode of heat loss. Although some additional benefit can be obtained from using both, more often only one or the other is used. 
Another method for saving energy for heating water is the use of a "hot water saver." This device saves energy by pushing the warm water in the pipes into the tank after water is drawn back into the tank. The basic approach is to effectively replace the wars water left in the pipes with cold water. The actual savings from this device can vary significantly depending on the frequency of hot water use, the length of piping, and a variety of other factors.

Timers that turn off water heaters at night or during the day when the occupants are regularly out of the house save only a small portion of the standby load (EK and Auberg 1984). These timers save energy only as slowly dropping water temperatures gradually reduce heat loss from the tank. The standby loads saved while the timer is off shift almost entirely to later in the day, when the timer allows the water, by then cooler than normal, to be reheated to the normal set point in a single, large warmup event.

\subsection{WATER HEATING ENERGY IN THE REGIONAL PLANNING PROCESS}

This section is subdivided into two topics: regional planning processes regarding standby loads and demand loacis. Brief discussions of the planning processes, key assumptions, and sources of data are presented.

\subsubsection{Standby Loads}

Compliance with federal appliance efficiency standards (Federal Register 1977) will reduce heat losses in electric water heaters. Manufacturers of electric water heaters are already producing high-efficiency models by incorporating insulating fiaterials with higher $R$-values (polyurethane foams instead of fiberglass), increasing insulation thickness, and incorporating anticonvection valves in their designs. Water heaters have an average lifetime of about 12 years, after which they wear out and begin to leak (Northwest Power Planning Council 1991). Thus, in the course of the region's 20-year planning horizon, most water heaters will be replaced by new, more efficient models. 
As a result of the federal standards, the decrease in consumption per household for heating water will be equal to the difference between the heat losses of hot water tanks that would have been purchased in the absence of standards and the heat losses of current replacements. This energy savings is already embedded in the energy forecast and does not appear as a conservation resource. Heat losses of the new tanks are fairly well defined by appliance testing procedures and minimum requirements mandated by the federal standard; heat losses of the current population of tanks is much more uncertain and needs to be identified. Fundamental objectives of this analysis are to determine the standby loads for the hot water tanks metered as part of ELCAP and to compare this data to other data already collected.

The current baseline standby loads used for planning purposes are based on two types of data: laboratory measurements of heat losses (similar to tests mandated by the federal standord), and estimates based on metered water heater consumption from several studies. Heat losses measured in the laboratory are based on two tests of typical current tanks with nominal R-5 values (EK 1982; EK and Auberg 1984). Regressions were al so conducted of metered data from some of the field studies against the number of occupants in the homes and the $y$-axis intercepts (consumption for zero occupants) from another set of estimates of the curr. : standby loads. The averages for each data source, given equal weight, result in an estimated standby load of 1580 $\mathrm{kWh} / \mathrm{yr}$, with a range across the studies of about $\pm 20 \%$. The standby loads estimated from the field data are higher than the laboratory tests (Northwest Power Planning Council 1991).

The planning assumption for $1300 \mathrm{kWh} / \mathrm{yr}$ standby loads for existing tanks is consistent with the theoretical heat losses calculated for 52-gallon tanks with nominal R-5 insulation and a $70 \circ \mathrm{F}$ temperature difference between the hot water and the air surrounding the tank. Previous unpublished work using ELCAP data and a home-by-home approach to estimating heat losses produced a much lower heat loss estimate $(-1000 \mathrm{kWh} / \mathrm{yr})$; however, an average hot water tan temperature of $133^{\circ} \mathrm{F}$ and a tank location temperature of $70 \circ \mathrm{F}$ were measured for the homes. Resolving this discrepancy between the plinning assumption and the ELCAP results is the primary purpose of this analysis. Thus, the baseline 
heat loss of $1580 \mathrm{kWh} / \mathrm{yr}$, the nominal R-5 insulation level, and the $70 \circ \mathrm{F}$ standard operating condition are key assumptior.s examined in this analysis.

The effect of the federal standards requiring all water heaters sold to have an EF factor of 0.88 is assumed to reduce standby $10 a d s$ to $720 \mathrm{kWh}$ based on U.S. Department of Energy (DOE) testing requirements for every new water heater purchased. Only two further conservation measures were evaluated. These involve changing the tank for an EF of 0.88 with the federal standard to 0.95 and adding a bottom board of insulation under the tank. Savings from a 0.95 tank were adapted from DOE work on appliance standards (U.S. Department of Energy 1989). Savings from the bottom board were taken from field studies by Seattle City Light (Reese and Wall 1981), and a laboratory study by Bonneville Power Administration (Ek and Auberg 1984). There is significant uncertainty surrounding these estimates and any supplementary savings estimates that can be obtained from ELCAP data are desirable secondary objectives of this analysis. Finally, energy savings from these conservation measures are discounted to reflect additional space heating requirements resulting from the reduced internal heat gain as standby heat losses are reduced.

\subsubsection{Demand Loads}

Current baseline demand loads used in the regional planning process are based on an assumption of 2.7 occupants per household using an average of $1270 \mathrm{kWh} / \mathrm{yr}$. This corresponds to an estimated $6570 \mathrm{gal} /$ occupant-year (18 gal/occupant-day), which is very close to the average $6429 \mathrm{gal} / 0 \mathrm{ccupant}$ year obtained from several studies that used methods ranging from direct measurement to electrical submetering (Northwest Power Planning Council 1991).

Savings resulting from use of low-flow showerheads are estimated separately for new and existing households because new households are more likely to have lower flow showerheads already in place. Estimates were made based on the number of minutes per shower, the mix of hot and cold water, and the number of showers per person per year. 


\subsection{ANALYSIS OVERVIEN}

This two-part section presents an overview of the data and methodology used in the analysis. Section 4.1 briefly describes the ELCAP metered and survey data used in the analysis. Section 4.2 provides an overview of the methodology.

The nomenclature used to describe hot water electricity consumption in this report should be clear before proceeding with a description of the analysis. The term load generically refer's to instantaneous consumption of electricity, as represented here by the hourly metered data. The instantarieous or hourly load is usually expressed in units of power (kW). The cumulative loads over time are usually expressed in units of energy per unit of time (kWh/yr, for example). (a)

As we have discussed, we are considering the total hot water load to be comprised of two components: standby and demand. These are loads placed on the hot water system by the occupants, as opposed to electrical loads. The distinction is that the water heater does not necessarily react to these at the same time they occur. The standby loads represent the steady heat loss from the tank, which is relatively constant over time even though the electricity consumed to make up for this heat loss typically occurs during only one of several successive hours, as will be illustrated. Thus, in this report this rate of tank heat loss is referred to as the standby load, although it is expressed in terms of energy ( $\mathrm{kWh} / \mathrm{yr}$ ) to be consistent with the units of the planning assumptions used by Bonneville and the Council. The individual bursts of electricity consumption that make up this heat loss are referred to as standby events. Similarly, the average demand load is also expressed in units of energy ( $\mathrm{kWh} / \mathrm{yr})$.

(a) For convenience, most of our calculations, and hence some intermediate results presented in Section 5, are expressed in average watts. Average watts are simply the average, instead of the sum, of the hourly loads over a given time. They are convenient because the time period need not be accounted for explicitiy. 


\subsection{ELCAP DATA USED}

The metered ELCAP data used in this analysis consist of all data available on hourly water heating for all residential homes in the sample as of April 1989 (typically 3 to 4 years). Monthly loads and daily load shapes from a previous end-use databook summary using data through May 1988 (Pratt et a1. 1989) are used in Section 8 to place the standby and demand load estimates obtained in this study in perspective with the total hot water load. The metered end-use consumption data are subject to a rigorous test in which the sum of the end-uses must equal the total load for the home within the measurement error of the metering equipment. Data failing this test are excluded from the analysis. The metering equipment and protocol are described in detail by Parker, Pearson, and Sandusky (1985).

Results of the standby load analysis are divided into three segments, one for each of the ELCAP residential studies. The characteristics of these studies are summarized in Pratt et a1. (1989) and described in detail by Windell (1987). The Base Study, the largest study in ELCAP, contains 288 of the 449 single-family site-built homes in the ELCAP project, and is the most regionally representative of any of the studies. The Base Study forms the backbone of this analysis and is a regional sample of single-family, detached, site-built, owner-occupied homes with electric space heat.

The next largest study is the RSDP study, consisting of 105 new homes built as a demonstration of the Model Conservation Standards for space heat. As such, these homes do not represent a regional sample of construction practices or of occupant energy usage. Because hot water tanks in the RSDP study were undoubtedly new at the time of construction (1983-1984), they provide a view of the standby performance of tanks of that vintage. For this reason, they are included in the anaiysis, but theiv average standby load is reported separately.

Homes in other ELCAP studies are also analyzed here, and their average standby load is also reported separately. They include rental homes, manufactured homes, gas- or oil-heated homes, and duplexes. 
In Section 7, demand load estimates from all homes studied are used in analyzing effects of number and type of occupants on hot water consumption. The resulting increase in sample size is assumed to offset any possible bias introduced by varying occusant behavior in other studies compared to the Base Study. There is no particular reason to think the RSDP and other studies differ from the Base Study on demand use, as there is for standby loads.

Hot water tank characteristics for this analysis are drawn from extensive onsite inspections of each home (Bonneville Power Administration 1986). The number and size of water heaters in each home were recorded, along with notations as to standby conservation measures that were in place. The hot water tap temperature was measured by running a hot water faucet for a few minutes and measuring the water temperature with a thermometer. The inspections were conducted about the time the metering equipment was installed, primarily during mid-1984.

Data on the number and ages of the occupants were gathered annually through a series of mail and telephone surveys (Darwin et al. 1986; Ivey and Alley 1987; Windell 1987). Survey data from 1985 through $1988^{(a)}$ were used.

\subsection{SUMMARY OF THE TECHNICAL APPROACH}

Figure 4-1 illustrates hourly metered water heating data for a 2-day period. The height of each bar represents an hourly observation of the electricity consumed by the water heater (in kWh). The $x$-axis in this and many other plots in this report is the hour of the day, with midnight being the endpoint of hour 24. During the first day, heavy hot water use is indicated by continuous and relatively high consumption in the morning hours from 7 through 11 ( 7 through 11 a.m.) and again in the afternoon from hours 16

(a) Data were taken from a 1989 letter report to the Bonneville Power Administration from Pacific Northwest Laboratory, authors M. P. Hattrup and $M$. A. Halverson. 
Figure 4-1

Typical Hot Water Load - - Two Occupied Days

(Site 137 Days 1883-1884)

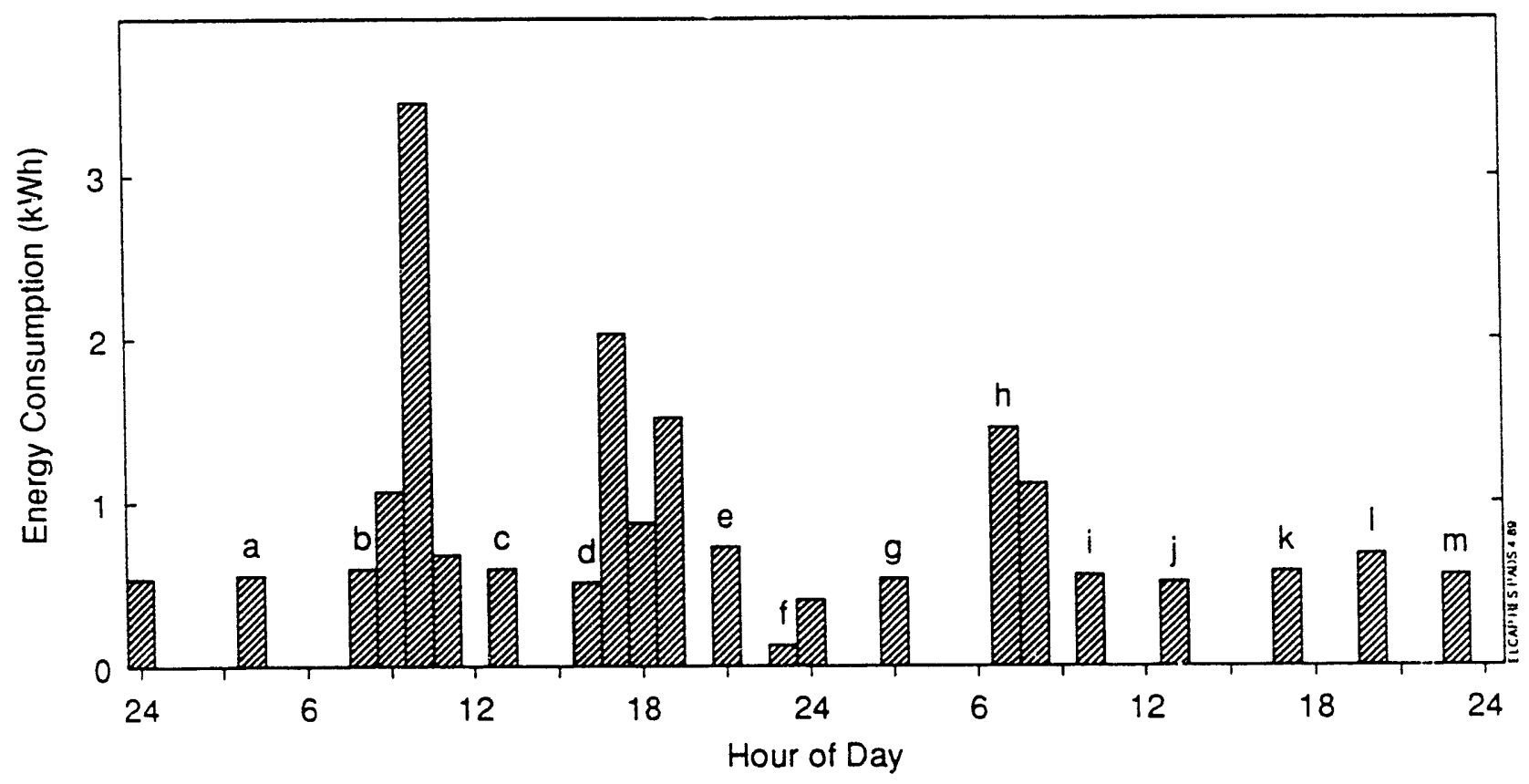

through 19 (4 through 7 p.m.). Less hot water is evidently used the following day, with heaviest consumption again occurring in the early morning hours.

Also notable in Figure 4-1 are numerous smaller, isolated events of fairly consistent magnitude (about $0.5 \mathrm{kWh}$ ) and frequency ( 3 to 4 hours apart), occurring most often at night. Their regularity suggests these are warmup events, where the tank is heated from the set point to the top of the thermostat deadband, as described in Section 3.1 and illustrated in Figure 3-2. The meaning of the letters marking some of the loads will be described later.

Figure 4-2 illustrates data from the same home, but whereas Figure 4-1 shows a typical period when the occupants are home, Figure 4-2 is a 2-day vacant period. During vacancies, water heater loads typically consist 
Figure 4-2

Typical Hot Water Load - - Two Vacant Days

(Site 137 Days 1886-1887)

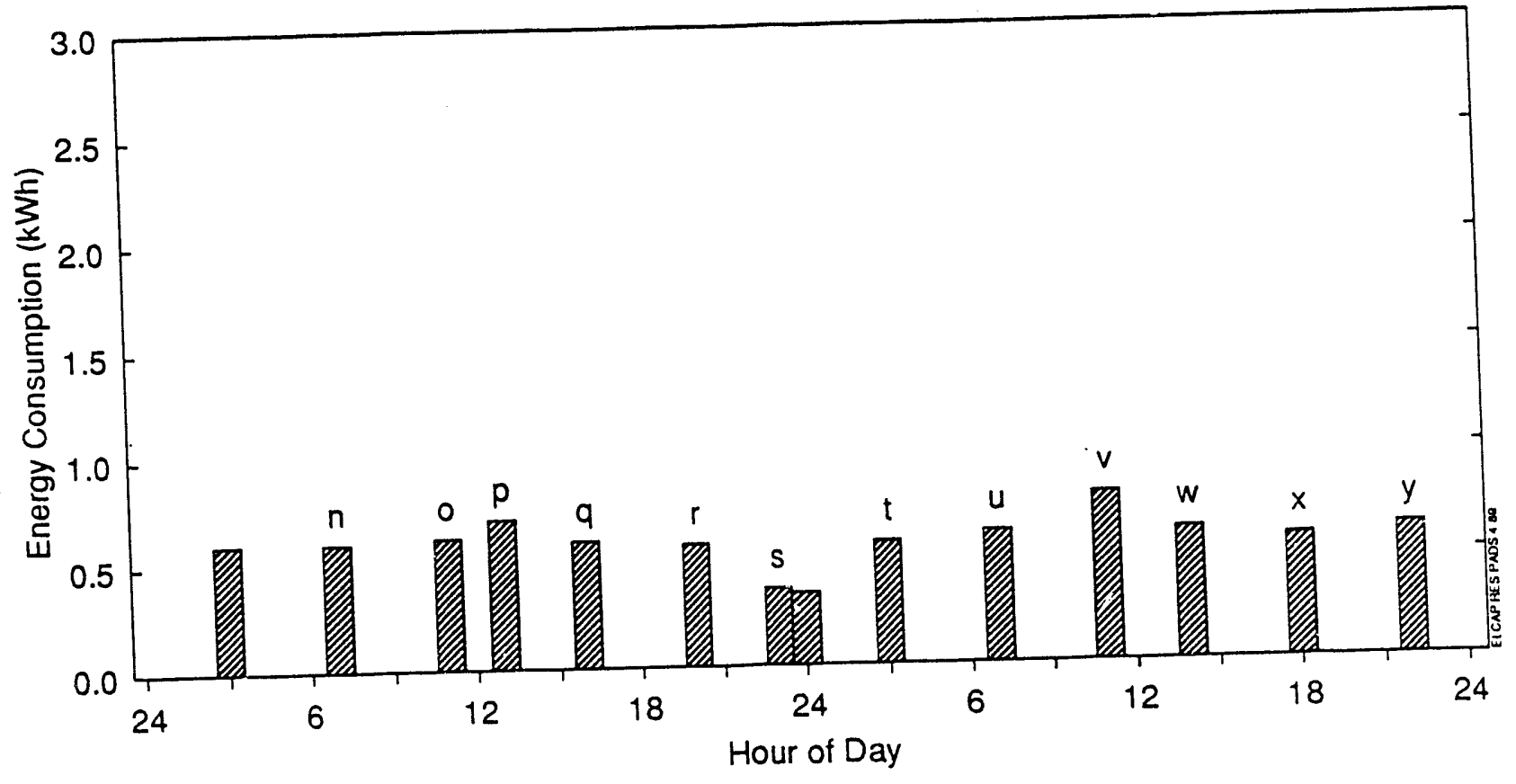

entirely of the regular uniform warmup events that characterize standby loads. This suggests using vacant periods to develop standby load estimates for each home when the entire water heating load consists of the standby load.

Unfortunately, vacant periods were not found for all homes in the sample. In addition, some occupants turn their water heaters off or turn the hot water temperature down during extended vacancies (such as vacations), thus making comparisons of vacant periods and occupied periods invalid. Such vacancy setback behavior is discussed in Section 5 . Therefore, it is desirable to develop a second method for estimating standby loads using data from occupied periods. The presence of numerous loads similar in magnitude and frequency during nighttime hours (and daytime periods when no hot water is used) suggests that these data could be used to estimate standby loads when usable vacant periods are not available.

This method can be used to estimate standby loads by combining all continuous hours of (non-zero) consumption into equivalent "events" with 
consumption equal to the sum of the individual hours involved and a start time equal to that of the first hour of the event. Each event defined in this way is labelled with a sequence of letters after the first event in Figures 4-1 and 4-2. Note that as a result, event "s" in Figure 4-2 has a magnitude which matches that of the other events during the vacancy. Many such events appear in 2 hours of the data because they occur just as the data logger clock changes the hour. Thus, part of their energy consumption is recorded in each of two adjacent hours.

The magnitude of each event and the interval preceding it (arbitrarily defined as the difference in its start time and that of the preceding event) can then be plotted in what is termed here an energy-interval diagram, as shown in Figure 4-3. The energy of each event is plotted on the $y$-axis and the preceding interval on the $x$-axis. Each labelled event in Figures 4-1 and 4-2 is plotted as a data point identified with its label in Figure 4-3. Major demand load events such as "b", "d", and " $h$ " stand out clearly in Figure 4-3 because of the magnitude of their energy consumption.

Figure 4-3

Typical Energy-Interval Diagram

(Site 137 Days 1883-1887)

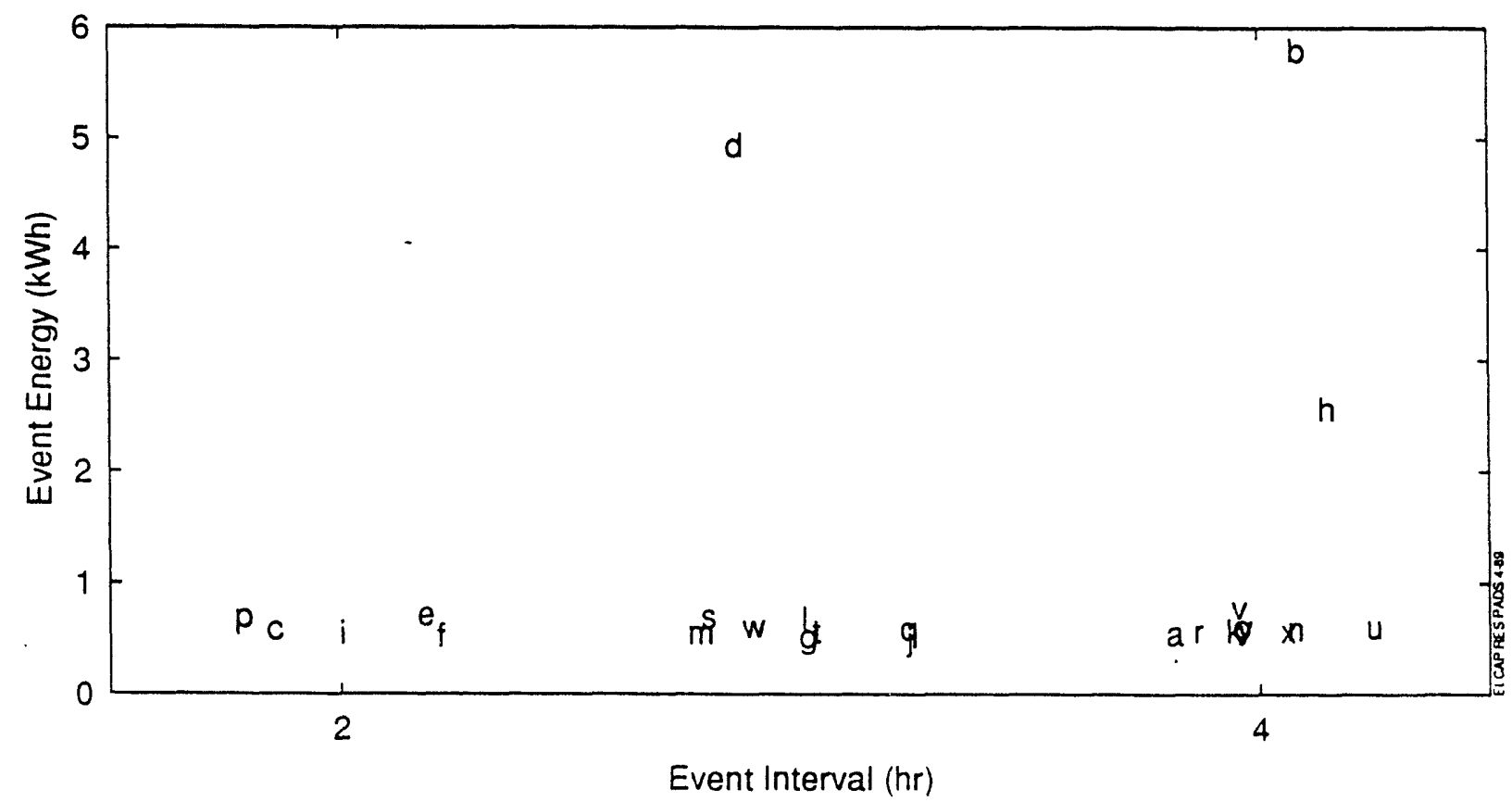


The event intervals in Figure 4-3 all range from 2 to 4 hours. Note that the computed intervals are actually all integers; a small amount of random noise has been added to the intervals plotted so that labels are readable. With the sole exception of event " $p$, " all vacancy events " $n$ " through " $y$ " have intervals of 3 or 4 hours. That these event intervals have a range of 2 hours is to be expected from the hourly time increment of the metered data. For example, a sequence of standby loads with an interval of 1.5 hours would occur at times 1.5 hours, 3.0 hours, 4.5 hours, 6.0 hours, and so on. Consequently, they would be recorded by the data logger as occurring during hours $1,3,4,6$ and so on.

Several events during the occupied periods also appear in the cluster of events with energies and intervals identifying them as standby events ("a," "g," "j," "k," "1," and "m"). Other events from the occupied period have similar energies but a shorter 2-hour duration ("c," "e," "i," and "f"). These are postulated as being "handwashing" events, as opposed to true standby events, as discussed below. Their common amount of energy classifies standby and handwashing events as warmup events, where the tank temperature increases from the hot water set point to the slightly higher thermostat deadband. The handwashing events, however, have shorter intervals.

Figure 4-4 shows the tank temperature falling from the set point of $134^{\circ} \mathrm{F}$. In a normal standby event, the warmup event indicated by the abrupt rise in the tank temperature occurs when the hot water set point temperature is reached at about hour 3.7. In the handwashing event, a small amount of hot water is suddenly withdrawn from the tank, just enough to trigger an earlier warmup at about hour 2.7, but not enough to noticeably deplete the tank of large amounts of additional energy. The same amount of energy is required to return the tank to the top of the thermostat deadband $\left(134^{\circ} \mathrm{F}\right)$ in either case. Thus, two types of warmup events are distinguished in this analysis -- true standby events and small-draw or handwashing events.

By designing a means of estimating the effects of handwashing events from the collection of all warmup events in the data from occupied periods, a means of estimating standby loads for homes without suitable vacancy periods 
Figure 4-4

Typical Handwashing Warmup Event

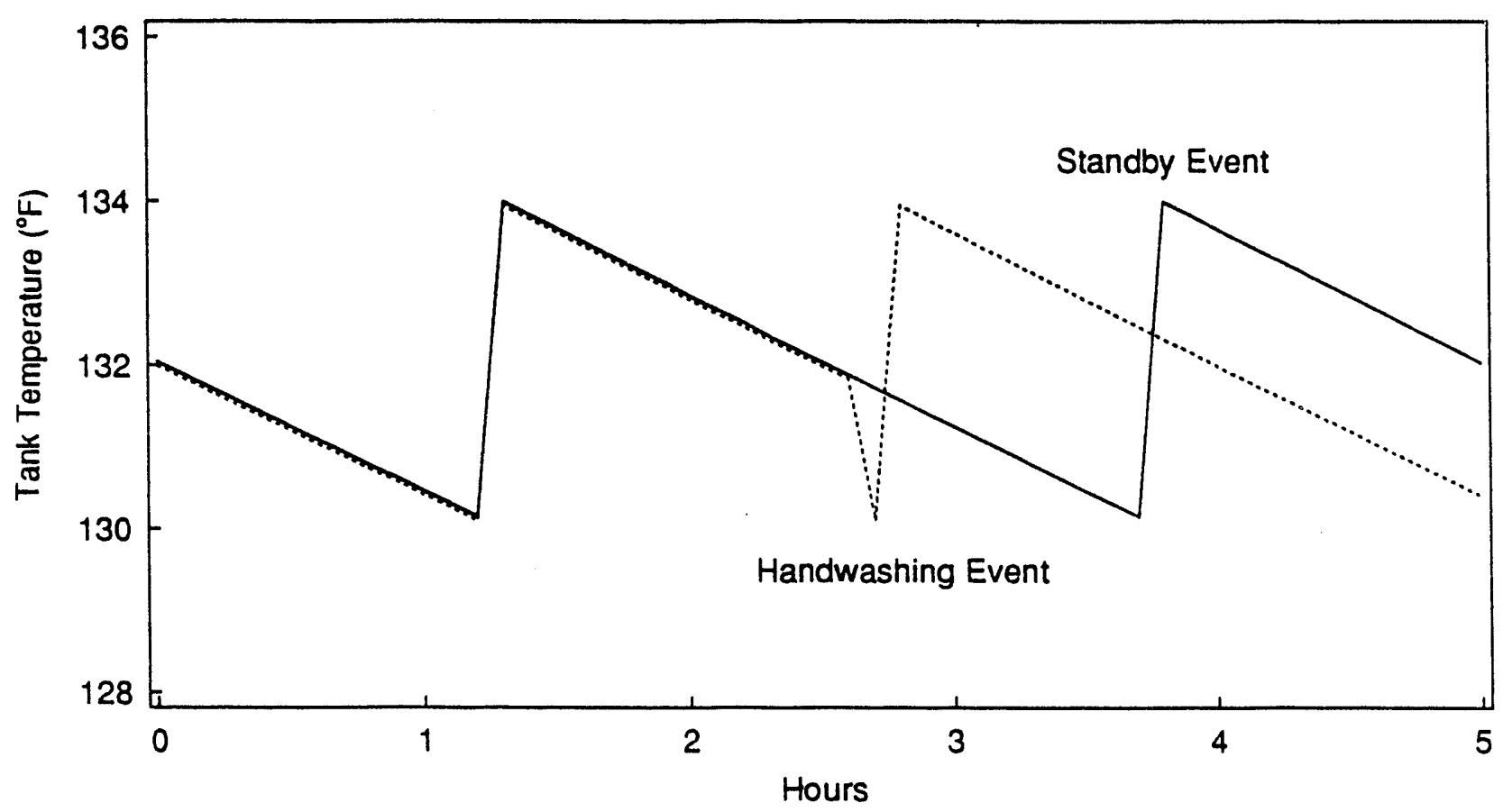

is developed. Tnis is accomplished by careful use and calibration of occupancy-based standby load estimates and vacancy-based estimates for homes from which both are obtained with a high degree of confidence. This process is described in detail in Section 6.

The standby estimates obtained for each home are easily adjusted for variations in surrounding air temperature by using Equation (3-2) to obtain standby loads under average temperature conditions. Once an estimate of the surrounding air temperature is made based on a weighted average of metered indoor and outdoor temperatures, dividing the standby load by the difference in the hot water and surrounding air temperatures gives the tank heat loss coefficients and the EF-factors used by the federal standard. Dividing the resulting heat loss coefficient (UA) by the surface area of each tank, estimated on the basis of the size of the tank (in gallons) and typical tank sizes from manufacturer data, gives the effective $U$-value and hence the effective R-value of each tank. These effective R-values implicitly include 
pipe heat losses and any conservation measures that may be present. These adjustments are described in Section 5 and the results reported in Section 6 .

Nominal R-values, including water heater wraps, are then estimated, albeit with considerably less precision, by adjusting for 1) lower R-values for top and bottom areas of the tank, 2) pipe losses based on manufacturer data, and 3) any conservation measures using results of laboratory tests of conservation measure impacts. These adjustments are also described in Section 5 and the results presented in Section 6 .

Once standby estimates are obtained for as many tanks as possible, demand estimates are obtained from the total metered hot water load by simple subtraction. The standby and demand estimates are then used with data on tank and occupant characteristics in regression analyses to estimate the effects of conservation measures on standby loads and the number and ages of occupants on demand loads. These results are reported in Sections 6 and 7 , respectively. 


\subsection{STANDBY LOAD ESTIMATION METHODOLOGY}

This section of the report provides detail on the methodology used in the analysis of standby loads. To reduce the scope of the discussion, this section focuses only on the major processes of the analysis. Peripheral issues and analyses are relegated to the appendices. Some results are included in this section where they serve to illustrate the development of the method, its application, and any biases that may result. Principal results of the standby load analysis are summarized in Section 6, so readers who are not interested in details of the method used to estimate standby loads can skip this section.

Section 5 is organized into five parts. Section 5.1 describes the filter used to eliminate insignificant demand events from the time series data and isolate warmup events of both the standby and handwashing types. Section 5.2 discusses how standby loads are estimated, including adjustments made for varying air temperatures and for the effect of handwashing events. Section 5.3 discusses the occurrence of two non-ideal patterns: vacancy setbacks and dueling thermostats. Section $\mathbf{5 . 4}$ describes how further filtering of the data is used to reduce the effect of two sources of error in the standby estimates for vacancy periods, and Section 5.5 defines the occupied/unoccupied calibration ratio.

\subsection{WARMUP EVENT FILTER}

As discussed in Section 4, a reasonable approach to estimating standby loads for water heaters is to focus on the warmup events that tend to occur with repeated magnitudes and at regular intervals.

A principal problem in working with 3 years of hourly time series data from hundreds of homes is the amount of computational work required. To reduce this work, a filter was designed that eliminates as possible standby events all events not significant to the analysis. The time series nature of 
the data is maintained by tracking the times of all events retained (in hours from the start of the data time series). The filter is described as a series of steps:

Step 1. Correct the original time series for possible offset drifts in the data logging equipment. This process, described in Appendix A, serves to correct very low hourly values ( $\sim 20$ watts), which are actually zero loads, that are recorded by the data loggers. (This algorithm may be of interest to other analysts of ELCAP data who need to correct offset drifts for appliances that have zero consumption at least a few hours each day.)

Step 2. Eliminate all hours with zero loads.

Step 3. Eliminate all periods of missing data except the first and last missing values in each episode. Retain these as a place holder for the event interval calculations.

Step 4. Compute the time interval between all remaining loads in the reduced time series. Time intervals for loads following the missing data place holders are marked as invalid. Intervals for any loads in the hour immediately preceding missing data periods are also considered invalid because the load may have continued but not been recorded. This vector of time intervals will now be filtered along with the hourly data.

Step 5. Eliminate all sequences of two or more continuous hours of non-zero loads. Because warmup events are of very short duration, typically 10 minutes or less, this step el iminates the multihour loads that characterize major hot water demands typical of daytime and evening use.

As discussed in Section 4, portions of single warmup events may be recorded in two adjacent hours when the warmup event occurs just as the clock hour of the data logger is ending. This double recording will be eliminated by Step 5 , but there should be numerous other events that occur entirely within clock hours. At this point, the original volume of hourly data has been reduced to an easily managed size, and remailing loads in adjacent hours can be combined into events and processed further.

Step 6. Following a nonwarmup event, the tank may be left in a partially depleted condition (i.e., with a temperature between the hot water setpoint and the top of the thermostat deadband). Drop the first 
of any adjacent warmup events. Note that this step will only keep the second, third, fourth, etc. warmup events in a series of warmup events. Single isoldted warmup events will be dropped.

The reniaining events, all potential standby events, are contaminated only by handwashing events and small demand loads of l-hour duration t'rat foliow a potential standby event.

\subsection{STANDBY LOAD ESTIMATION}

The stardhy load at any point in time is the average rate of energy consumption when the tank is in the standhy mode. This can be computed for any standby evant as the energy consumed during the event $\left(Q_{e}\right)$ divided by the preceding interval $\left(\Delta t_{e}\right)$. The average standby load over a number of events (n) can then be computed either as the mean ene: ? divided by the mean interval

$$
Q_{\text {standby }}=\frac{\left(\frac{1}{n}\right) \Sigma Q_{e}}{\left(\frac{1}{n}\right) \Sigma \Delta t_{e}}
$$

or as the mean of the energy divided by the interval of each event

$$
Q_{\text {standby }}=\frac{1}{n} \sum \frac{Q_{\theta}}{\Delta t_{\theta}}
$$

Equation (5-1) is used in this analysis. As discussed in Section 4.2, even under ideal conditions such as vacancies with constant air temperatures surrounding the hot water tank, standby events in hourly time series data will almost always be recorded as occurring with two distinct intervals that differ by 1 hour. Variations in the surrounding air temperatures over the course of 
the metering may cause further variation in the intervals, approximately equal to a $\pm 10^{\circ} \mathrm{F}$ swing compared to a tank-air temperature difference of abnut $700 \mathrm{~F}$ ( $.10 / 70$, equal to $\pm 15 \%$ ). Varying air temperatures can introduce variation of one or more (for tanks with very long intervals between standby events) additional hours.

Even if standby event energies $\left(Q_{e}\right)$ are perfectly constant, a true average is not obtained using Equation (5-2) because it effectively averages the reciprocal of the time intervals, while Equation (5-1) gives a properly weighted average of the time intervals observed. As will become clear from the discussion that follows, there are additional compelling reasons for using Equation (5-1) to estimate standby loads.

Air temperature around hot water tanks may differ considerably during vacancy periods. The temperatures may be higher or lower than normal, depending on the season of the year and the tank location. According to data from occupied periods, lower air temperatures are also likely during the nighttime, when most standby events usable in the analysis are detected. Therefore, standby loads are adjusted for differences in the air temperature for each event and the average air temperature for all data. This adjustment is given by a simple manipulation of the heat loss equation. The heat loss coefficient (UA) is a property of the tank, not the temperatures, so Equation (3-2) can be rearranged and applied to both instantaneous and long-term averas= conditions

$U A=Q_{\text {standby }} /\left(T_{\text {hot }}-T_{\text {local }}\right)=Q^{*}$ standby $/\left(T_{\text {hot }}-T^{*}{ }_{\text {local }}\right)$

where the * indicates long-term averages, and as before $T_{\text {hot }}$ is the hot water setpoint and $T_{\text {local }}$ is the temperature of the air at the tank location. Equation (5-3) can be rearranged to give the average standby load under average conditions.

$$
Q_{\text {standby }}^{*}=Q_{\text {standby }}\left(T_{\text {hot }}-T^{*}{ }_{\text {local }}\right) /\left(T_{\text {hot }}-T_{\text {local }}\right)
$$


These adjustments are applied to each event remaining after the standby event filter is applied. Because the variation in temperature causes variation in event intervals, but not event energies, the reciprocal of this adjustment is applied to the event intervals

$$
\Delta t_{e}^{\star}=\Delta t_{e}\left(T_{\text {hot }}-T_{\text {local }}\right) /\left(T_{\text {hot }}-T^{\star}{ }_{\text {local }}\right)
$$

This adjustment is made before the average standby load is computed for each home using Equation (5-1).

To make the air temperature adjustment, local tank temperatures are estimated based on tank location. For tanks in conditioned living spaces (not heated basements), local air temperature and indoor air temperature measured by the ELCAP data loggers are assumed to be equal. Similarly, measured outdoor air temperatures are used for outdoor tanks, and weighted averages of indoor and outdoor temperatures are used for tanks in heated and unheated basements, crawlspaces, porches and garages as suggested by Hanford et al. (1985). This technique has been used for other analyses (Northwest Power Planning council 1991). The methodology is described in Appendix $C$.

It is important to note that, unlike a previous unpublished analysis of ELCAP standby loads, the temperature adjustment does not convert the standby lcad for each tank based on a common air temperature assumed to exist for all tanks. Instead, it applies a smaller adjustment, converting it to the average location temperature for each individual home.

The fundamental approach used in the analysis is to estimate the average standby load using estimates for individual homes based on data from periods of vacancy, wherever possible. However, for some homes vacant periods may not be detected, or the homes may have water heater characteristics (multiple tanks, timers, solar assist) that invalidate any estimate obtained. It is desirable, however, to obtain standby estimates for as many metered homes as possible to estimate demand loads (by subtraction from the total hot water load) for the analysis of the influence of number and age of the occupants in Section 7 , and to reduce biases in average standby estimates that may result from using only those homes with vacancy-based estimates. 
To estimate standby loads for homes without vacant periods, a calibration ratio is estimated that adjusts the standby loads from occupied periods to better represent that from vacant periods. The calibration ratio can be computed for each home when both vacant and occupied period estimates are available. Using the average calibration ratio, the occupied standby load estimates for homes without vacant periods can then be adjusted accordingly. This approach implicitly assumes that the warmup events in occupied periods are "polluted" by handwashing events that form a relatively constant fraction of energy consumed by the set of warmup events identified for the home. Because increased uncertainty results from using these estimates in the analysis, the standby load estimates presented in Section 6 include averages for the homes with vacancy-based estimates (for a smaller group of homes) and for al1 homes 'using the adjusted occupancy-based estimates where necessary).

\subsection{INVESTIGATION OF NON-IDEAL STANDBY EVENT PATTERNS}

An unresolved issue identified in previous unpublished analyses of ELCAP standby loads is that although many homes exhibit relatively ideal patterns of standby events, non-ideal patterns of events also occur. Comparing standby load estimates from vacant and occupied periods for individual homes reveals two types of non-ideal patterns: vacancy setbacks and dueling thermostats. These are discussed in sections 5.3.1 and 5.3.2.

\subsubsection{Vacancy Setbacks}

The first type of non-ideal standby event pattern, referred to as a vacancy setback, is illustrated in the energy-interval diagram of Figure 5.1, which plots event energies and intervals from three consecutive days: an occupied day, a vacant day, and one intervening transition day. (The algorithm for vacancy identification is described in Appendix B.) This nonideal pattern is characterized by very constant event energies, as expected, but also by an unexpectedly broad band of intervals. In this case, the intervals range over 4 hours (from 2 to 6 hours). Ranges of 10 hours or more where observed. 
Figure 5-1

Typical Energy-Interval Diagram - Vacancy Setback

(Site 341 Days 2568-2570)

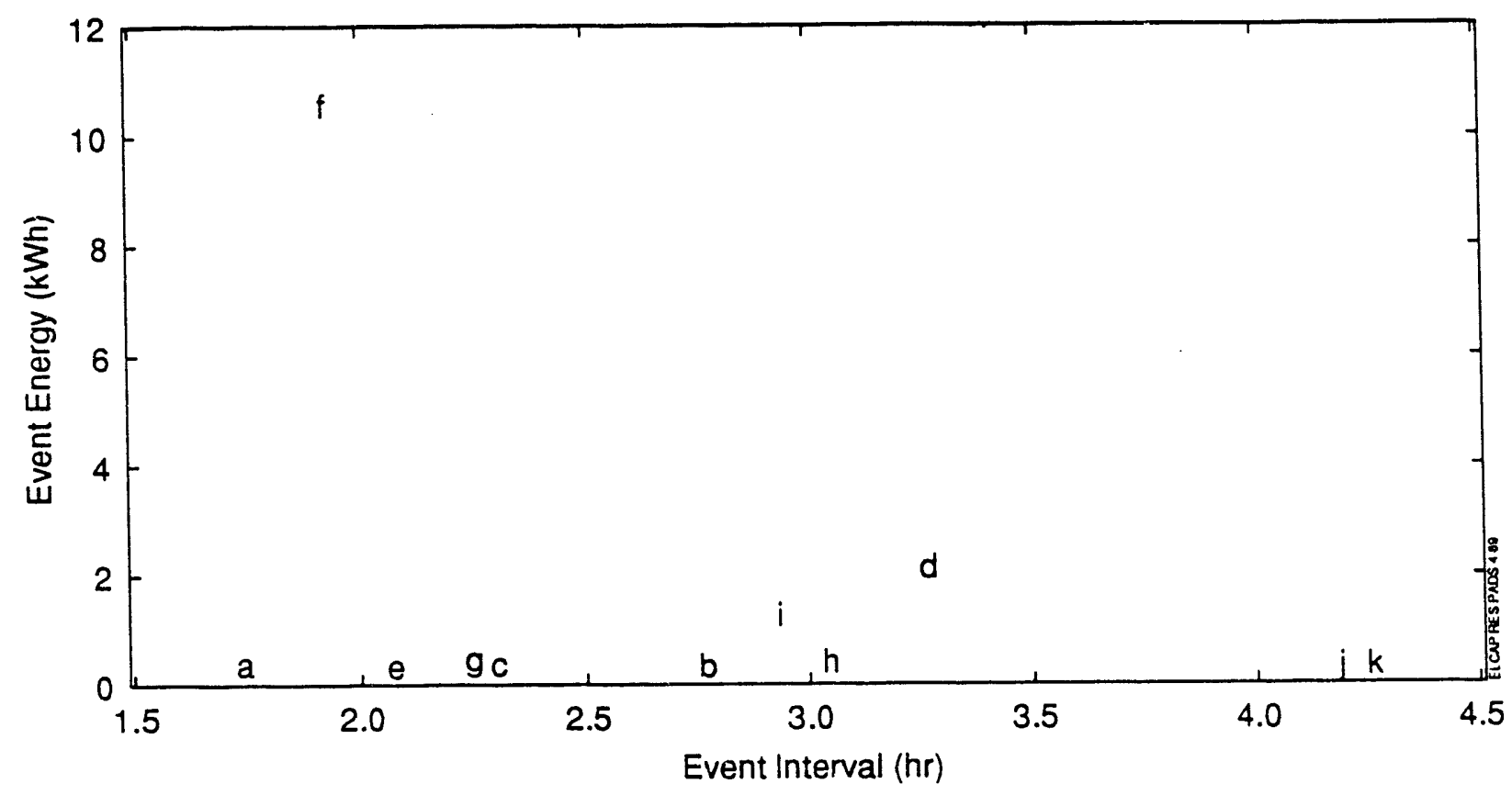

By examining the time series data shown in Figure 5-2 for these same 3 days, several potential standby events can be identified in the first day on the basis of the standby event filter described earlier in Section 5 (events "a," "b," "c," and " $h ")$. Al1 these potential standby events have intervals of 2 or 3 hours, as indicated by the energy-interval diagram in Figure 5-1. After the last demand load at hours 5 and 6 on the second day (event " $i$ " in Figure 5-2), the absence of further demand events indicates the vacancy. All potential standby events from the vacant period (events " $k$ " through " $p$ " in Figure 5-2) have intervals of 4 to 6 hours. This pattern is confirmed by examining other occupied/vacancy transition periods for the same home.

The interpretation here is that the occupant has lowered the tank thermostat to save energy while the house is vacant. It is at first surprising that the occupant would not simply turn off the tank at the circuit 
Figure 5-2

Typical Hot Water Loads - Vacancy Setback

(Site 341 Days 2568-2570)

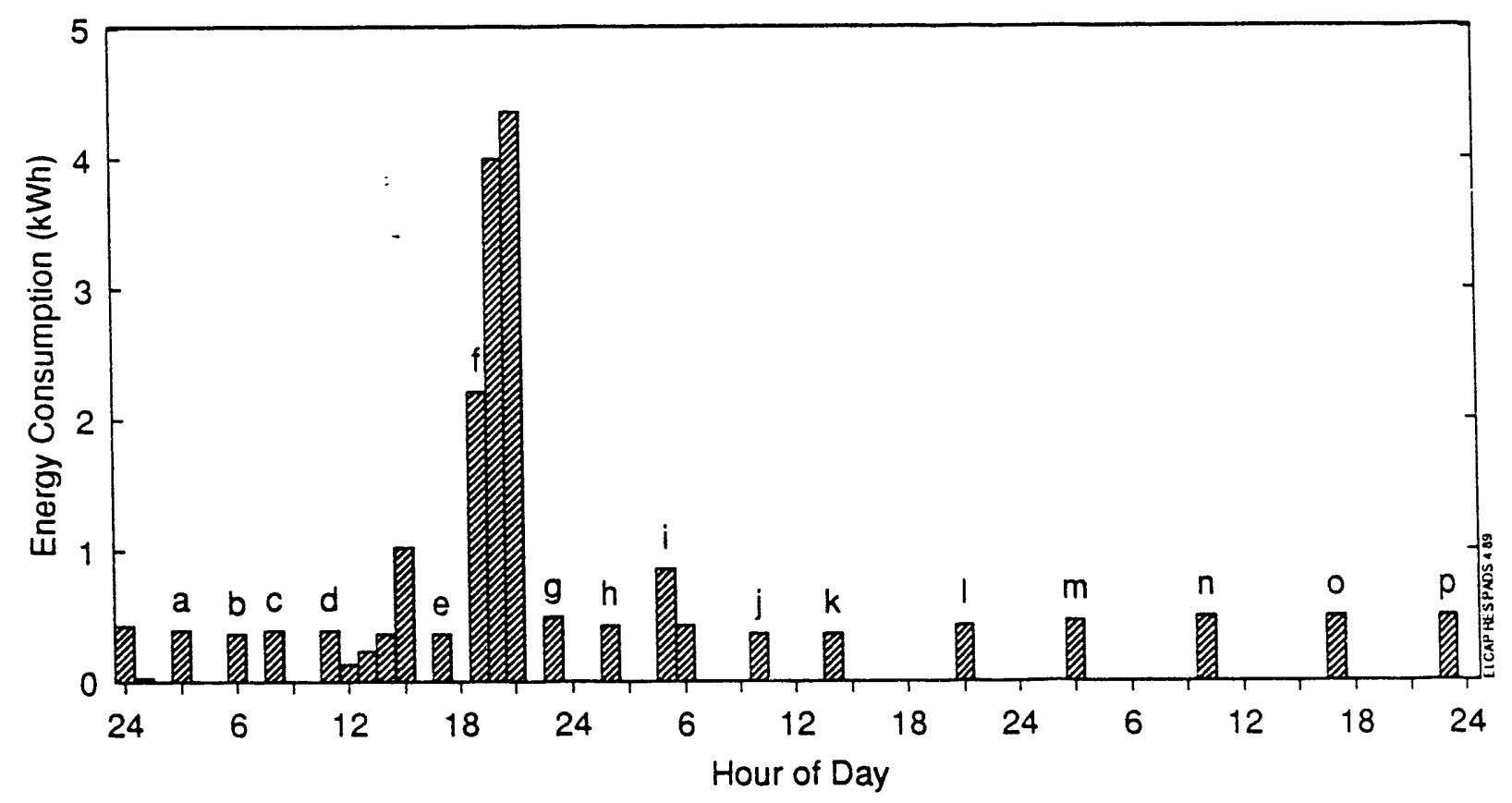

breaker panel. Anecdotal evidence obtained by interviewing readily available groups of homeowners revealed, however, that some do turn down the ir tank thermostats when on vacation. Reasons for this ranged from ignorance "I never thought of using the breaker." to fear that the tank would freeze in cold weather. Turning off hot water tanks with the circuit breakers during vacancies undoubtedly prevents estimation of vacancy-based standby load for some homes, even when these periods of vacancy are detected.

In the day after a vacancy with a setback, an extraordinarily large (high energy) warmup event will occur as the tank is reheated to normal operating temperatures. This event will also have an unusually long preceding interval compared to other potential standby events from occupied periods. As a result, an additional precautionary step is added to the standby filter described in the Section 5.1: 
Step 7. Eliminate the first potential standby event after a period of vacancy.

\subsubsection{Dueling Thermostats}

A second type of non-ideal standby event pattern, referred to as dueling thermostats, has been identified in this analysis. The energy-interval diagram in Figure 5-3 illustrates data from a 10-day standby event pattern: two occupied and eight succeeding vacant days. The corresponding time series data are shown in Figure 5-4. The standby events at this home show large variation in both energy and interval, even during the vacancy period that begins after event "f."

Figure 5-3

Typical Energy-Interval Diagram -- Dueling Thermostats

(Site 84 Days 1181-1890)

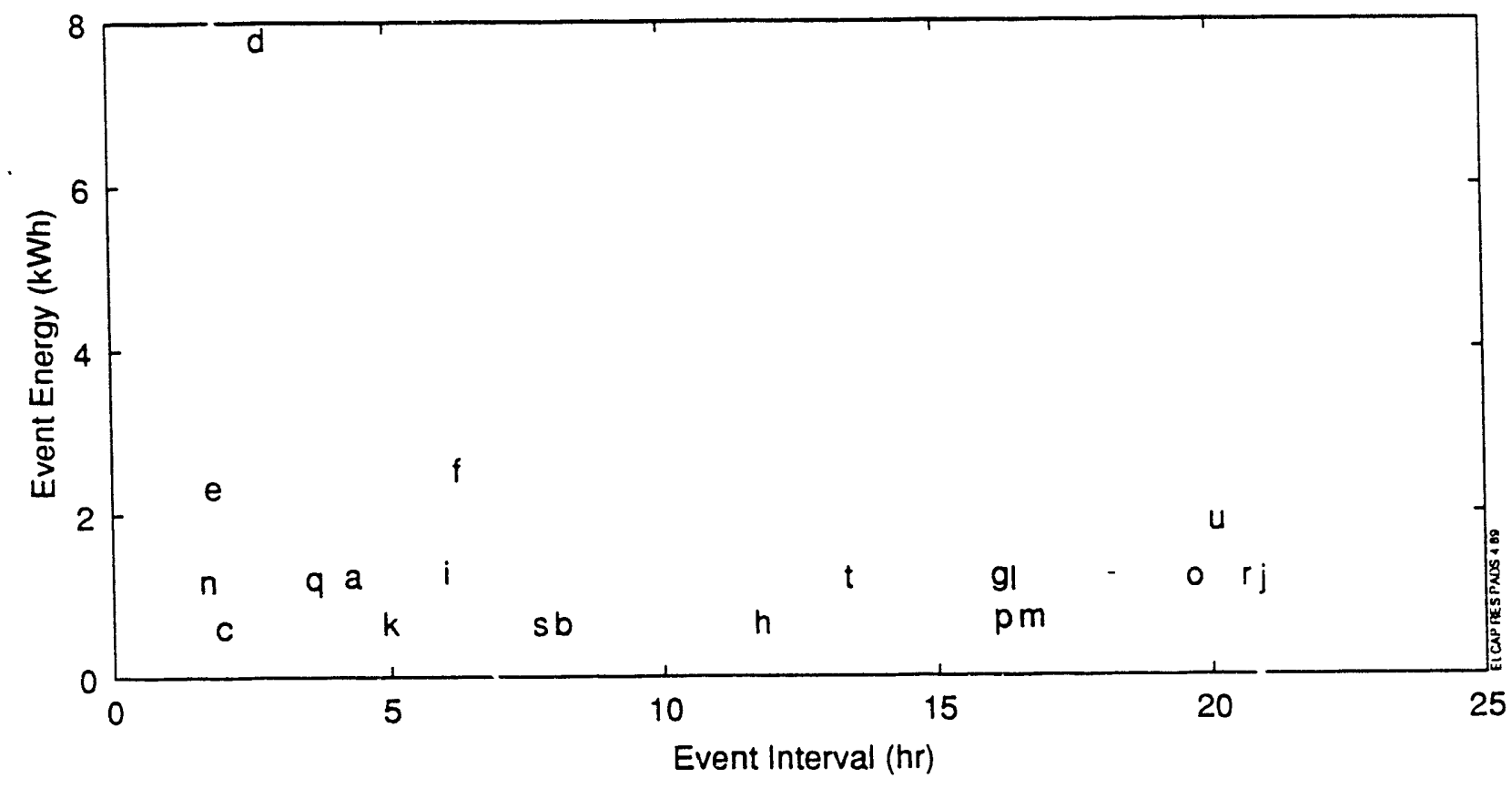


Figure 5-4

Typical Hot Water Loads -- Dueling Thermostats

(Site 84 Days 1181-1890)

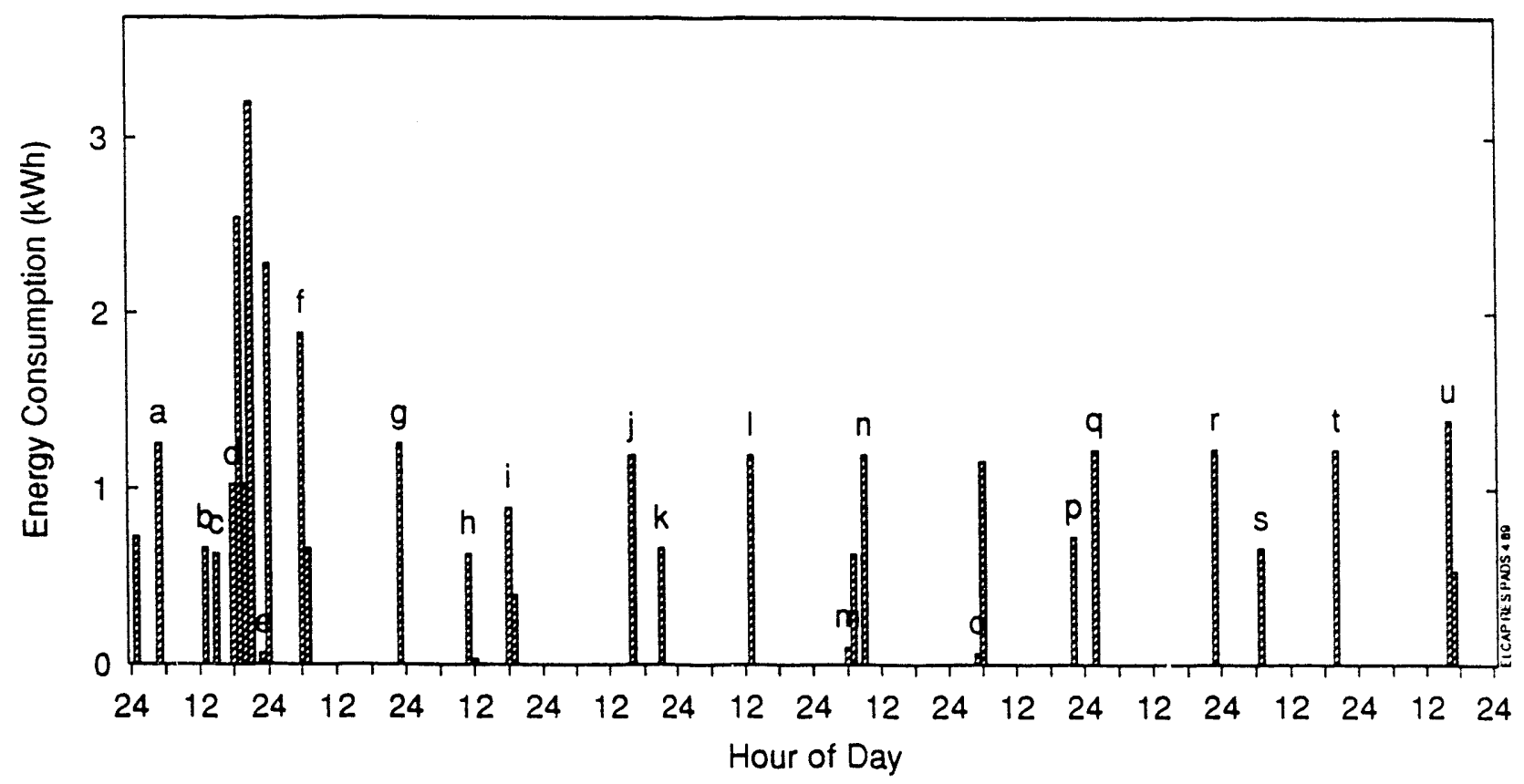

A plausible explanation for this seemingly random pattern of standby events is not obvious. A failure in the vacancy detection algorithm was suspected, but the vacancy period clearly lacks the large demand events that occur during normal occupied periods. To investigate possible explanations, a simple thermal simulation of a hot water tank was constructed. The simulation is described in Appendix D.

Figure 5-5 shows results of a simulated hot water tank containing two heating elements, with the bottom thermostat set at a slightly lower temperature than the upper thermostat (hence the term dueling thermostats). The top element heats only the water above it. The bottom element heats only the water below the top element, unless the water in the upper portion of the tank is cooler than the bottom thermostat setpoint plus its deadband. In this case it heats all the water in the tank to this temperature. 
Figure 5-5

Simulation of Tank with Dueling Thermostats

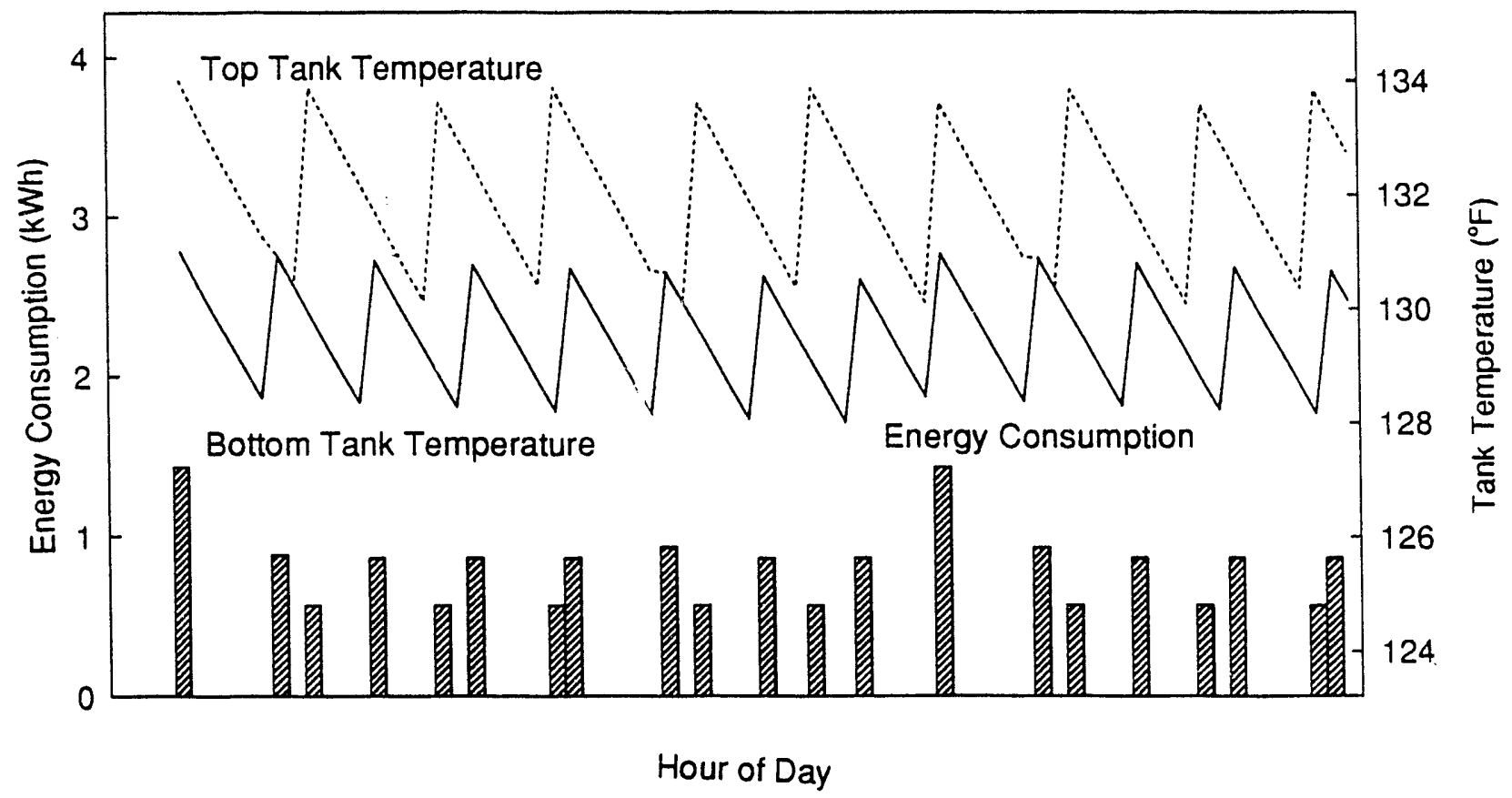

In the case illustrated by Figure 5-5, the top element is assumed to be one-third of the way down the tank. The two thermostats are assumed to have deadbands that differ by $1{ }^{\circ} \mathrm{F}$ (which can also represent the effects of cooler water settling to the bottom of the tank, as discussed in Appendix D). The result is a chaotic pattern of standby events very similar to those observed in the time series data shown by Figure 5-4. If the upper thermostat setpoint is slightly below the lower setpoint, no dueling occurs.

Standby events from the upper and lower portions of the tank have different magnitudes because of the uneven portions of the tank they heat. Because of the unequal deadbands, the tanks also have different frequencies, which only occasionally cause the events to occur during the same hour. The unequal deadbands cause the uneven intervals of the standby events and occasional large event energies that are equal to the sum of the normal energies for the upper and lower tank. These effects are observed in the data in Figure 5-4. Finally, twice during the hot water tank simulation the bottom element heated the water in the upper part of the tank somewhat, thus 
disturbing the upper tank cycle time and adding further "noise" to the event energies.

\subsection{VACANCY SETBACK AND DUELING THERMOSTAT DETECTION}

Clearly, vacancy-based standby estimates from homes with vacancy setbacks do not represent the normal standby loads for these homes. Because these estimates must not be used in the analysis, homes that normally set back their tank thermostats during vacancies must be identified.

The effect of dueling thermostats is uncertain. The varying time intervals and the correlation of the interval with the event energy (the longest intervals occur when the upper and lower tank events coincide -- the largest possible event energy) strongly support the use of Equation (5-1) for computing the average load. However, the shortest possible intervals (in successive hours) are eliminated by the standby filter described in Section 5.1 , potentially biasing the result. This section describes how vacancy setbacks and dueling thermostats are identified from the data.

Visually determining whether a setback has occurred for an individual vacancy for some homes is easy. Setbacks are clearly indicated when the vacancy and occupied event intervals never overlap. When dueling thermostats are also present, the broad ranges of event intervals may overlap considerably. Interestingly, as discussed below, many homes that clearly set back also exhibit dueling thermostats. This makes sense, because the resetting of the upper and lower thermostats after the vacancy is unlikely to be uniform. Thus, dueling thermostats patterns may not be consistent throughout the metered time series.

Because any given home may not set back during every vacancy, particularly short periods of a day or two, deciding whether a home generally exhibits setback behavior is somewhat arbitrary. So, like dueling thermostats, setback behavior may be inconsistent. Because dueling thermostats are most easily detected during vacancies, data are examined for 
both vacancy setbacks and dueling thermostats for each individual period of vacancy. The steps in this process are as follows:

Step 1. Calculate summary statistics (the maximum, median, mean, and minimum) for the intervals of the potential standby events in each occupied period and each vacancy period.

Step 2. Eliminate periods in which only three or fewer potential standby events were identified.

Step 3. Eliminate periods with uncertain occupancy. (The vacancy detection algorithm, described in Appendix B, classifies vacancies as probable or unlikely as well as certainly occupied or certainly unoccupied.) These are often days of transition between occupied and vacant periods.

Step 4. Eliminate occupied periods in which the potential standby events represent more than $50 \%$ of the time series. Under normal occupied conditions, demand loads and their preceding intervals form a large majority of the time series. This step eliminates short periods of occupancy that may be incorrectly identified as such, or that may be occupied only briefly in a "caretaker" scenario. These are dropped because a setback may still be in effect.

Step 5. Combine the statistics of any adjacent occupied periods or any vacant periods that result from elimination of the intervening periods by Steps 2 though 4 .

Steps 1 through 5 create a simple summary of the pattern of potential standby events for the home during each period. This pattern is then analyzed in a process, developed through trial and error, that mimics the process of visually examining the data to make overall judgements about whether vacancy setbacks or dueling thermostats are indicated in each period. Because the judgements about the occurrence of vacancy setbacks are difficult, two levels of judgement are applied: a strict criteria indicating certain setbacks, and a less strict criteria indicating suspected setbacks. Continuing the detection process:

Step 6. Flag each remaining vacancy period as indicating dueling thermostats if the range of event intervals is more than 3 hours.

Step 7. Score each remaining vacancy period as a "suspected" setback if the maximum vacancy interval is more than 0.5 hours longer than the maximum occupied interval, AND 
- the maximum vacancy interval is more than $10 \%$ longer than the maximum occupied interval, AND

- the period is flagged as dueling OR the median vacancy interval is greater than the maximum occupied interval.

The first and second criteria must hold if dueling thermostats are detected. The third criteria ensures the range of intervals in the two periods do not overlap to a large extent if dueling thermostats are not detected. One-half of a point is given to the suspected setback score for comparison with each of the preceding and following occupied periods.

Step 8. Score each remaining vacancy period as a "certain" setback if

- setbacks are suspected relative to both the preceding and following occupied periods (i.e., the suspected setback score is 1.0$)$, AND

- the minimum occupied interval is greater than the maximum unoccupied interval OR dueling thermostats are flagged as certain.

Step 9. Determine the average dueling thermostat and suspected and certain vacancy setback scores for all vacancy periods analyzed for the home.

The detection of dueling thermostats and vacancy setbacks for any given vacancy period is intentionally fairly liberal. Averaging across all time periods in Step 9 to get an overall score for the home gives only minimal weight to the "judgements" applied to each individual period. These overall scores are then used to classify the validity of each home's vacancy estimate and develop the calibration ratio, as described in Section 5.5 of this report.

\subsection{OCCUPIED/UNOCCUPIED CALIBRATION RATIO}

The calibration ratio is defined here as the average ratio of the occupied and vacancy standby estimates for all homes with valid vacancy estimates. This ratio is multiplied by the occupancy-based standby estimate to obtain an adjusted standby estimate. The adjustment accounts for the average "contamination" by handwashing and single-hour demand loads remaining in the original occupancy estimate after the standby filter has been applied (see Section 5.1). 


\subsubsection{Number of Homes Available for Analysis}

Standby estimates were produced for 399 homes overa11, with 305 homes also having a vacancy estimate. Homes with solar water heaters, setback timers, and more than one electric hot water tank are clearly going to produce erroneous standby estimates and are excluded here. This reduced the number of occupied and vacancy standby estimates to 331 and 265 , respectively.

Any homes that did not have at least 20 potential standby events from vacancy periods were eliminated, with 177 valid vacancy-based standby estimates remaining. Some homes had unknown tank locations ${ }^{(a)}$ or lacked valid indoor air temperatures on which to base the tank location air temperature adjustments. This further reduced the number of homes with standby estimates ready for analysis to 289 (occupied) and 150 (unoccupied).

\subsubsection{Use of Trimmed or Untrimmed Means}

Recognizing that some handwashing events and 1-hour demand events remain in the events summary after the standby filtering was applied, the use of trimmed means in computing the standby estimates was investigated as a method of reducing the impact of these "contaminating" events. A trimmed mean is the mean of the data with a given fraction of the highest and lowest data eliminated. Thus, a $10 \%$ trimmed mean eliminates the highest and lowest $10 \%$ of the values and is equal to the mean of the remaining $80 \%$ of the values from the middle of the distribution.

(a) Hot water tank locations were originally only classified in the ELCAP characteristics data as being in numbered conditioned or unconditioned zones, or outdoors. To refine the tank location data, floor plan sketches made as part of the onsite inspections (Bonneville Power Administration 1986) were individually examined. Zone numbers were matched to a classification of zones into conditioned primary spaces; heated basements; heated daylight (partial) basements; unheated porches, sunspaces, or utility rooms (larger than closets); unheated basements; crawlspaces; and garages. The specific location of the hot water heater was noted in the process. This new characteristics data set may be valuable for other analyses of ELCAP data. 
Table 5-1 shows mean standby estimates for the homes based on vacancy periods, occupied periods, occupied periods for the homes that al so have a vacancy-based estimate, and the resulting calibration ratio calculated using untrimmed and two trimmed means (10\% and $25 \%$ ). Also included for comparison is the mean event ratio, the estimate based on the mean of the standby estimates obtained for each individual event at a home, see Equation (5-2). The number of homes in each sample is indicated. The results for the calibration homes, discussed in the following section, are al so included.

\section{TABLE 5-1}

Mean Standby Loads and the Calibration Ratio for the Homes in the ELCAP Sample (average watts, except ratios)

\begin{tabular}{|c|c|c|c|c|c|}
\hline Sample & $\frac{\text { Ratio of } \mathrm{Me}}{\text { Untrimmed }}$ & $\frac{\text { an Energy to }}{\text { Trimmed } 10 \%}$ & $\frac{\text { Mean Interval }}{\text { Trimmed } 25 \%}$ & $\begin{array}{l}\text { Mean } \\
\text { Event } \\
\text { Ratio }\end{array}$ & $\begin{array}{l}\text { No. of } \\
\text { Homes }\end{array}$ \\
\hline \multicolumn{6}{|l|}{ A11 Estimates Obtained } \\
\hline $\begin{array}{l}\text { Vacant } \\
\text { Occupied (all est.) } \\
\text { Occupied (and vacant) } \\
\text { Calibration Ratio }\end{array}$ & $\begin{array}{r}125 \\
187 \\
187 \\
1.66\end{array}$ & $\begin{array}{r}124 \\
176 \\
176 \\
1.57\end{array}$ & $\begin{array}{r}124 \\
174 \\
174 \\
1.55\end{array}$ & $\begin{array}{r}139 \\
225 \\
225 \\
1.80\end{array}$ & $\begin{array}{l}305 \\
399 \\
305 \\
305\end{array}$ \\
\hline \multicolumn{6}{|l|}{ Valid Estimates } \\
\hline $\begin{array}{l}\text { Vacant } \\
\text { Occupied (all est.) } \\
\text { Occupied (and vacant) } \\
\text { Calibration Ratio }\end{array}$ & $\begin{array}{r}117 \\
185 \\
175 \\
1.58\end{array}$ & $\begin{array}{l}116 \\
174 \\
164 \\
1.49\end{array}$ & $\begin{array}{r}116 \\
172 \\
161 \\
1.46\end{array}$ & $\begin{array}{r}131 \\
222 \\
209 \\
1.69\end{array}$ & $\begin{array}{l}177 \\
321 \\
177 \\
177\end{array}$ \\
\hline \multicolumn{6}{|c|}{ Valid, Temperature Adjusted } \\
\hline $\begin{array}{l}\text { Vacant } \\
\text { Occupied (al1 est.) } \\
\text { Occupied (and vacant) } \\
\text { Calibration Ratio }\end{array}$ & $\begin{array}{r}113 \\
182 \\
173 \\
1.63\end{array}$ & $\begin{array}{r}114 \\
172 \\
162 \\
1.52\end{array}$ & $\begin{array}{r}114 \\
171 \\
160 \\
1.49\end{array}$ & $\begin{array}{r}129 \\
221 \\
208 \\
1.72\end{array}$ & $\begin{array}{l}150 \\
289 \\
150 \\
150\end{array}$ \\
\hline \multicolumn{6}{|c|}{ Calibration, Temperature Adjusted } \\
\hline $\begin{array}{l}\text { Vacant } \\
\text { Occupied (al1 est.) } \\
\text { Occupied (and vacant) } \\
\text { Calibration Ratio }\end{array}$ & $\begin{array}{r}123 \\
166 \\
166 \\
1.39\end{array}$ & $\begin{array}{r}123 \\
156 \\
156 \\
1.30\end{array}$ & $\begin{array}{r}124 \\
155 \\
155 \\
1.29\end{array}$ & $\begin{array}{l}136 \\
193 \\
193 \\
1.47\end{array}$ & $\begin{array}{l}104 \\
104 \\
104 \\
104\end{array}$ \\
\hline
\end{tabular}


The units of the standby loads in Table 5-1 are average watts, ${ }^{(a)}$ as are other tables presenting intermediate results. All tables presenting final results are in units of $\mathrm{kWh} / \mathrm{yr}$.

Because it does not produce a proper average (as discussed in Section 5.2), the mean event ratio produces relatively higher standby loads, particularly for occupied periods, and is not discussed or used further. The trimmed mean standby estimates are seen to produce estimates nearly identical to the untrimmed mean for vacancy estimates, but significantly higher estimates for the occupied periods. This suggests that the use of trimmed means is effect in reducing the effects of the handwashing and 1-hour demand events from the filtered occupied standby events. The value of the 25\% trimmed means beyond the 10\% trimmed means appears marginal, so $10 \%$ trimmed means are used for the remainder of the results presented in this report.

For convenience, standby estimates based on the $10 \%$ trimmed means are summarized in Table 5-2 for these same groups of homes. Table 5-2 highlights the fact that the temperature adjustments have a negligible effect on the overall results.

TABLE 5-2

Standby Estimates (10\% trimmed mean) and Calibration Ratios for ELCAP Homes in the Analysis

\begin{tabular}{lcccccc}
\hline $\begin{array}{c}\text { Sample } \\
\text { Analyzed }\end{array}$ & $\begin{array}{c}\text { Vacant } \\
\text { (avg.watts) }\end{array}$ & $\begin{array}{c}\text { Occupied } \\
\text { All Est. } \\
\text { (avg.watts) }\end{array}$ & $\begin{array}{c}\text { Occupied } \\
\text { and Vacant } \\
\text { (avg.watts) }\end{array}$ & $\begin{array}{c}\text { Calibra- } \\
\text { tion } \\
\text { Ratio }\end{array}$ & $\begin{array}{c}\text { No. of } \\
\text { Aill }\end{array}$ & $\begin{array}{c}\text { No. of } \\
\text { Homes, } \\
\text { Vacant }\end{array}$ \\
\hline All & 124 & 176 & 176 & 1.57 & 399 & 305 \\
Valid & 116 & 174 & 164 & 1.49 & 321 & 177 \\
Adjusted & 114 & 172 & 162 & 1.52 & 289 & 150 \\
Calibration & 123 & 156 & 156 & 1.30 & 104 & 104 \\
\hline
\end{tabular}

(a) An average watt is the average energy consumed per hour, a convenient unit of analysis for ELCAP data, and can be converted to the more familiar units of kilowatt-hours (kWh) by multiplying by 8.76 . 


\subsubsection{Determination of the Calibration Ratio}

The distributions of the scores for dueling thermostats and both suspected and certain vacancy setbacks obtained from the detection process described in Section 5.3 do not cluster into two groups that distinguish those homes that do from those that do not show these patterns of standby events. If selected criteria are too tight, the size of the remaining sample used for determining the calibration ratio will be greatly reduced. If criteria are too loose, bias in the finai estimates will result.

To help select appropriate cutoff points for these criteria, plots were made of the calibration ratio resulting from the full range of setback scores anij the resulting calibration sample size. Figure 5-6 shows the calibration ratio as a function of the cutoff values selected for the two setback criteria. Each line represents the result for a constant value of the certain setback frequency, indicated as a label on each line. Similarly, Figure 5-7 shows the calibration sample size as a function of the same criteria.

Figure 5-6

Calibration Ratio as a Function of Setback Frequency Criteria

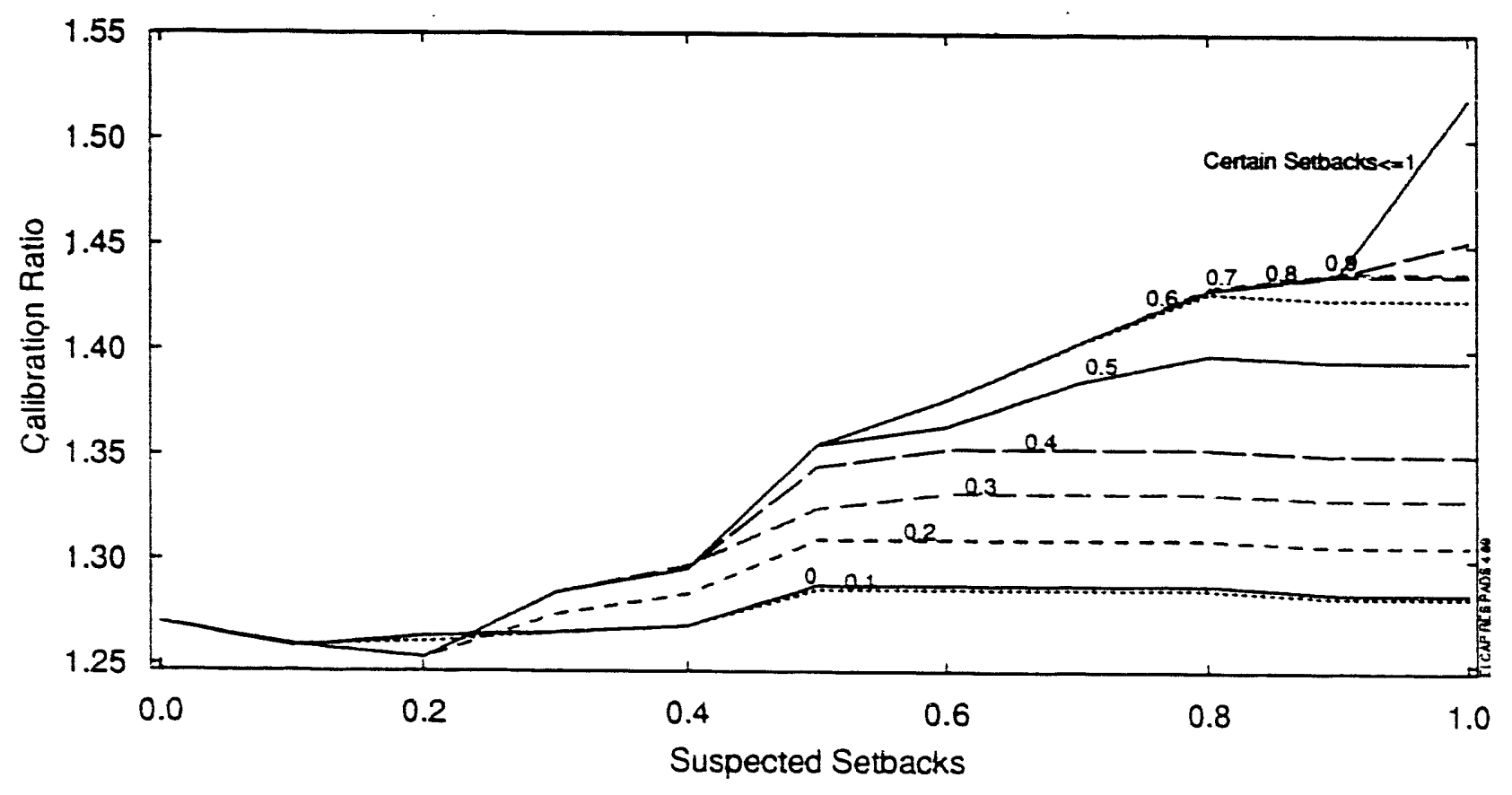


Figure 5-7

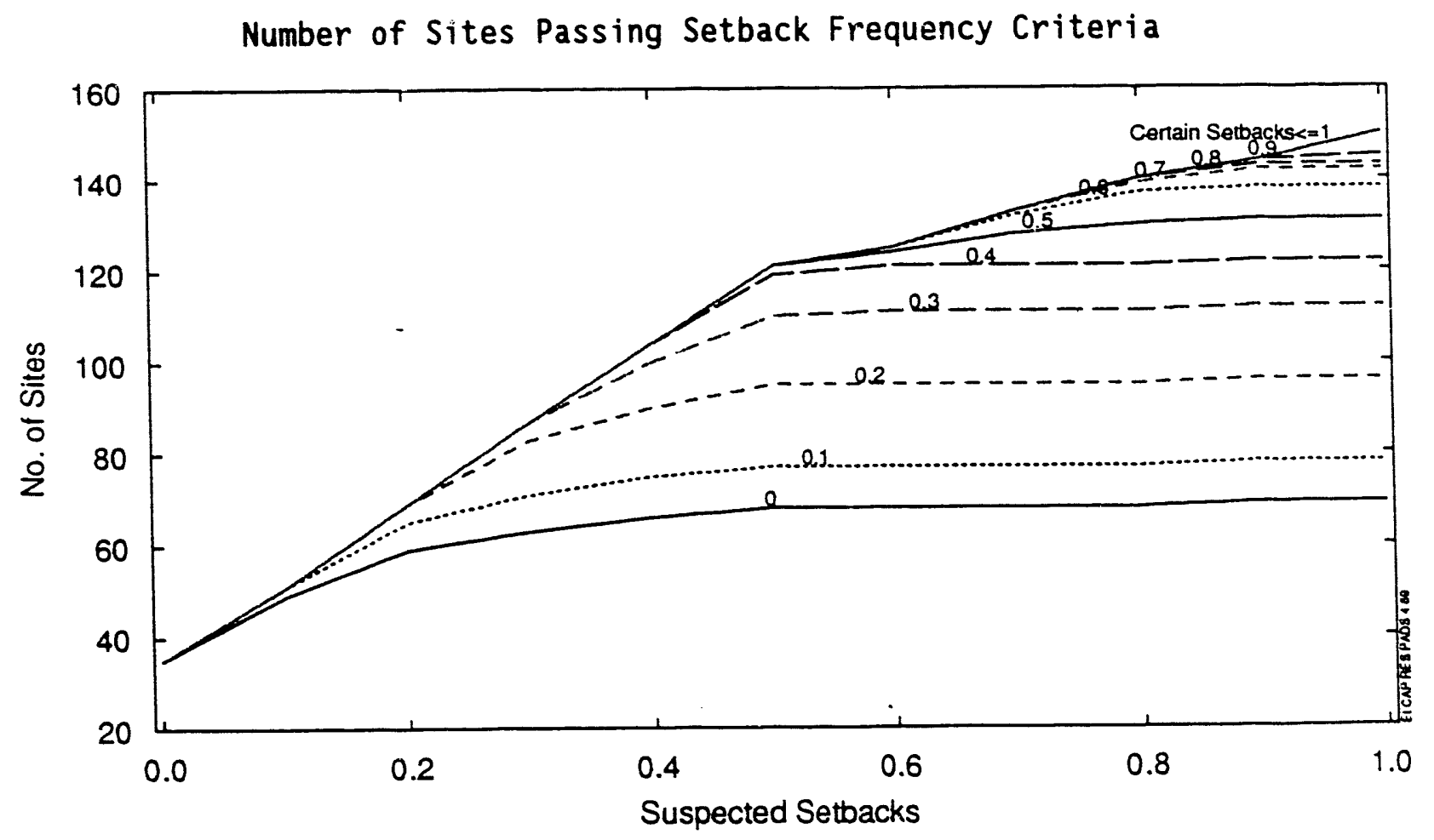

As both criteria become stricter, Figure 5-6 shows that the calibration ratio stabilizes at a little less than 1.3 for a criteria of certain setbacks detected for less than $40 \%$ of the vacancies (the line labelled 0.4 ). The calibration ratio is seen to vary only slightly if stricter criteria for suspected setbacks are used. Figure 5-7 indicates the sample size at this point is about 105 homes (actually 104), and begins to fall off rapidly for certain suspected setback detection frequencies of 0.5 or less. About onethird of the potential sample has been eliminated from setting the calibration ratio with this criteria. Use of a home with vacancy setback frequencies less than or equal to 0.4 seems appropriate.

Similarly, Figures 5-8 and 5-9 show the calibration ratio and sample sizes resulting from a combination of cutoff criteria for certain setback and dueling thermostat frequencies. Figure 5-8 indicates that the calibration ratio based on homes with certain setback ratios less than 0.4 is almost 
Figure 5-8

Calibration Ratio as a Function of

Dueling and Setback Frequency Criteria

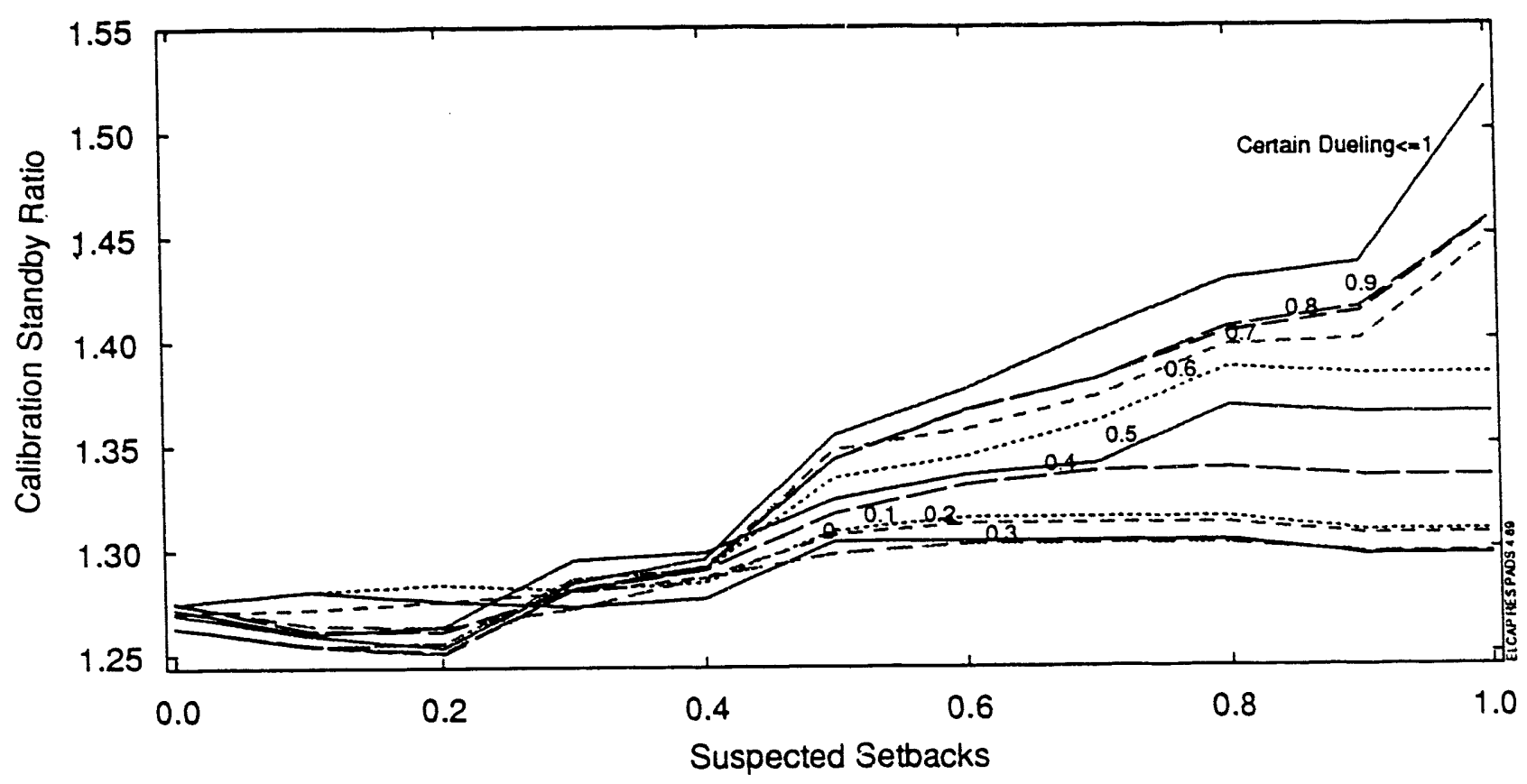

completely independent of the dueling thermostat frequency cutoff criteria used. (a) A calibration ratio of 1.3 , based solely on a calibration sample for homes with certain thermostat setback frequencies less than or equal to 0.4 , is therefore used in this analysis.

Appendix E contains detailed results (1ike Table 5-1) of an analysis of the dueling thermostat homes that remain in the calibration and noncalibration samples. The principal results of this analysis are summarized in Table 5-3. Table 5-3 shows that the homes with thermostat setback frequencies above 0.4

(a) The same is not true at higher cutoff values of the setback criteria, indicating the degree to which dueling thermostats appear to be associated with thermostat setbacks. 
Figure 5-9

Number of Sites Passing Setback and Dueling Criteria

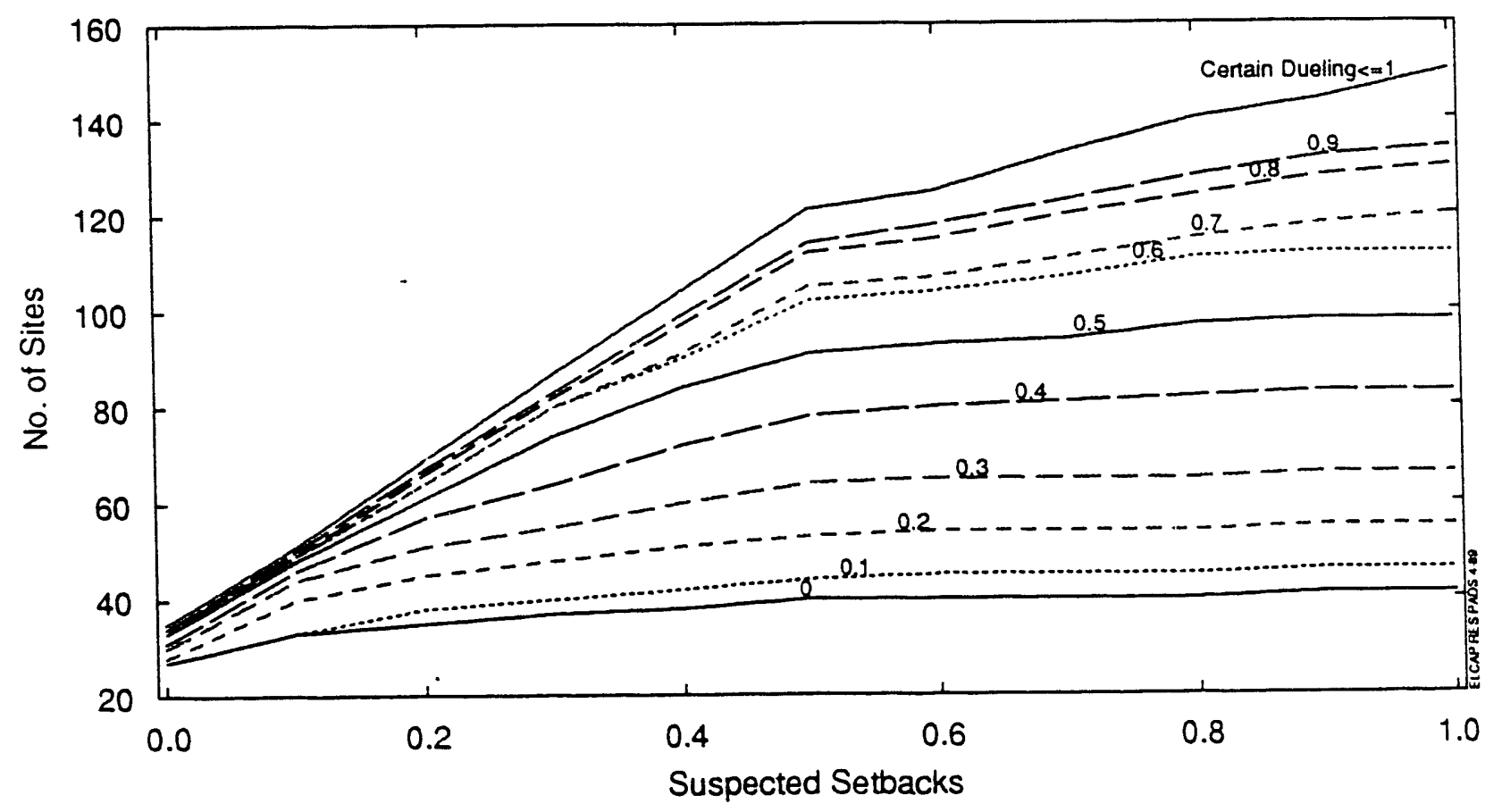

have very low standby load estimates. It also demonstrates that not excluding homes with dueling thermostat frequencies above 0.4 has a negligible effect on the calibration ratio. (a)

(a) The most notable result not shown here is for nondueling thermostat homes. Whether exhibiting thermostat setbacks or not, the standby estimate from the mean event ratio, Equation $(5-2)$, is nearly equal to the ratio of the mean event energy to the mean event interval used in the analysis. This result supports the dueling thermostat detection criteria and is consistent with how the mean event ratio is expected to interact with dueling thermostats. 
TABLE 5-3

Summary of Results: Standby Estimates (10\% trimmed mean) and Calibration Ratios for ELCAP Homes in the Analys is

\begin{tabular}{lcccccc}
\hline $\begin{array}{c}\text { Sample } \\
\text { Analyzed }\end{array}$ & $\begin{array}{c}\text { Vacant } \\
\text { (avg.watts) }\end{array}$ & $\begin{array}{c}\text { Occupied, } \\
\text { All Est. } \\
\text { (avg.watts) }\end{array}$ & $\begin{array}{c}\text { Occupied } \\
\text { and Vacant } \\
\text { (avg.watts) }\end{array}$ & $\begin{array}{c}\text { Calibra- } \\
\text { tion } \\
\text { Ratio }\end{array}$ & $\begin{array}{c}\text { No. of } \\
\text { All }\end{array}$ & $\begin{array}{c}\text { No. of } \\
\text { Homes, } \\
\text { Vacant }\end{array}$ \\
\hline $\begin{array}{l}\text { Calibration } \\
\text { Dueling }\end{array}$ & 123 & 156 & 156 & 1.30 & 104 & 104 \\
Not Duel. & 122 & 157 & 157 & 1.31 & 32 & 32 \\
$\begin{array}{l}\text { Noncalibration } \\
\text { Dueling }\end{array}$ & 92 & 155 & 155 & 1.29 & 72 & 72 \\
Not Duel. & 101 & 177 & 177 & 2.03 & 46 & 46 \\
& & 182 & 182 & 2.15 & 35 & 35 \\
& & 163 & 163 & 1.62 & 11 & 11 \\
\hline
\end{tabular}




\subsection{STANDBY LOAD RESULTS}

This section is divided into six parts. Section 6.1 discusses standby load results, and Section 6.2 discusses the importance that hot water tap temperature and temperature surrounding the water heater play in the results. Results of this section indicate a need for a clearer understanding of the assumptions used in previous regional planning estimates for standby loads. Sections $6.3,6.4$, and 6.5 indicate how the analytical results can be used to compare federal appliance efficiency standards to observed operating conditions for water heaters in the sample. This information is used in determining the effective and nominal tank.R-values. Finally, Section 6.6 discusses the impacts various conservation measures have on reducing standby load. These results are compared to earlier laboratory test results.

\subsection{AVERAGE STANDBY LOADS}

Table 6-1 shows the temperature-adjusted mean standby load estimates for the hot water tanks in the calibration sample by ELCAP study (Base, RSDP, and other) and by tank location. Also shown are standby estimates extrapolated to the entire sample of valid homes. This extrapolation is accomplished by using the product of the calibration ratio and the standby estimate from occupied periods for each home to provide an estimate of the true standby load for homes without a valid vacancy-based estimate (the noncalibration homes). This adjustment is made to obtain a larger s mple size and so demand loads can be estimated by subtraction. Details of the development of the calibration ratio are presented in Section 5. (Similar tables comparing occupied and vacancybased standby estimates for a 11 homes, both adjusted and unadjusted for temperature, are provided in Appendix F.)

Table 6-1 shows the average extrapolated standby load for the Base Study is just under $1200 \mathrm{kWh} / \mathrm{yr}$, and for the RSDP study is just under $1100 \mathrm{kWh} / \mathrm{yr}$. The Council's estimates for an unwrapped R-5 tank are about the same as this, around $300 \mathrm{kWh} / \mathrm{yr}$. A possible explanation for this difference is that Base Study homes may have additional conservation measures. Inspection data 
TABLE 6-1

Calibration and Extrapolated Standby Estimates in $\mathrm{kWh} / \mathrm{yr}$

\begin{tabular}{|c|c|c|c|c|c|c|}
\hline \multirow[b]{2}{*}{ Sample } & \multicolumn{3}{|c|}{ Calibration Homes } & \multicolumn{3}{|c|}{ Extrapolated } \\
\hline & Mean & $n$ & S.Dev. & Mean & $n$ & S.Dev. \\
\hline A11 ELCAP & 1078 & 104 & 289 & 1162 & 289 & 418 \\
\hline $\begin{array}{l}\text { Base-A11 } \\
\text { - Occupied Zone } \\
\text { - Heated Basement } \\
\text {-Dayl ight Basement } \\
\text { - Unheated Basement } \\
\text { - Porch/Sunspace } \\
\text { - Crawlspace } \\
\text { - Garage } \\
\text {-Outdoors }\end{array}$ & $\begin{array}{c}1092 \\
1117 \\
1114 \\
1185 \\
995 \\
- \\
1079 \\
1076 \\
-\end{array}$ & $\begin{array}{r}63 \\
22 \\
13 \\
4 \\
10 \\
0 \\
5 \\
9 \\
0\end{array}$ & $\begin{array}{l}284 \\
290 \\
361 \\
257 \\
277 \\
- \\
265 \\
207 \\
-\end{array}$ & $\begin{array}{l}1191 \\
1168 \\
1158 \\
1439 \\
1206 \\
1408 \\
1340 \\
1151 \\
736\end{array}$ & $\begin{array}{r}182 \\
60 \\
43 \\
7 \\
26 \\
2 \\
13 \\
30 \\
1\end{array}$ & $\begin{array}{r}457 \\
411 \\
454 \\
502 \\
369 \\
470 \\
569 \\
559 \\
0\end{array}$ \\
\hline $\begin{array}{l}\text { RSDP-A11 } \\
\text {-Occupied Zone } \\
\text { - Heated Basement } \\
\text {-Daylight Basement } \\
\text { - Unheated Basement } \\
\text { - Porch/Sunspace } \\
\text {-Crawlspace } \\
\text { - Garage } \\
\text {-Outdoors }\end{array}$ & $\begin{array}{c}1013 \\
1026 \\
998 \\
1449 \\
- \\
- \\
840 \\
1000 \\
-\end{array}$ & $\begin{array}{r}30 \\
16 \\
5 \\
1 \\
0 \\
0 \\
3 \\
5 \\
0\end{array}$ & $\begin{array}{c}280 \\
213 \\
441 \\
0 \\
- \\
- \\
129 \\
351 \\
-\end{array}$ & $\begin{array}{c}1075 \\
1068 \\
1128 \\
1099 \\
1246 \\
- \\
989 \\
1016 \\
-\end{array}$ & $\begin{array}{r}75 \\
35 \\
15 \\
4 \\
3 \\
0 \\
5 \\
13 \\
0\end{array}$ & $\begin{array}{l}301 \\
266 \\
402 \\
288 \\
295 \\
- \\
350 \\
274 \\
-\end{array}$ \\
\hline Other-A11 & 1176 & 11 & 334 & 1202 & 32 & 401 \\
\hline
\end{tabular}

indicate that $41 \%$ of water heaters in the ELCAP sample are wrapped, $9 \%$ have bottom boards, and $2 \%$ were noted to have thermal traps. How these figures compare to the region as a whole in 1984 is unknown, but this could account for all or part of the discrepancy. The Council's estimate for an unwrapped tank with an EF of 0.88 is $720 \mathrm{kWh} / \mathrm{yr}$. This is the level of the new federal standard that took effect in 1990. It is not clear how the water heaters in the RSDP sample, which were new in 1984 , relate to this level of efficiency.

Standby estimates for the calibration sample tend to be about $9 \%$ and $6 \%$ less for the ELCAP and Base studies, respectively. This may represent real differences between hot water tanks and conditions in the calibration and 
extrapolated samples or an error in the calibration ratio caused by use of a setback criterion that is too strict. Further means of investigating reasons for this difference have not yet been developed.

For estimating demand loads as well as other analyses, it is desirable to estimate standby loads for as many homes as possible. Many homes that dropped out of the analysis did so because hot water tap temperatures, or in some cases indoor air temperatures, where unavailable. The missing temperature adjustment factors were filled in using the averages for homes from the same ELCAP study and with the same tank location. The additional estimates, summarized in Appendix F, differ only marginally from those in Table 6-1.

\subsection{HOT WATER TEMPERATURES AND TANK LOCATION TEMPERATURES}

Standby estimates obtained for the ELCAP homes and those used for regional planning may differ if average hot water temperatures or the mixture of tank locations (and hence the surrounding air temperatures) for the ELCAP homes differ markedly from the homes in the region. Table 6-2 shows the mean of all available ELCAP hot water temperatures and tank location temperatures broken down by ELCAP study and by tank location.

Hot water tap temperatures, approximately equal to hot water setpoints, average $138^{\circ} \mathrm{F}$ for the Base Study and $131^{\circ} \mathrm{F}$ for the RSDP study. The average in homes in the other studies is even higher -- $140 \circ \mathrm{F}$. This raises the overall ELCAP average to $137^{\circ} \mathrm{F}$.

The most common tank 1ocations for the Base Study are $34 \%$ in primary occupied spaces, $28 \%$ in heated and daylight basements, and $29 \%$ in both unheated basements and garages. The remainder were located on the porch/sunspace, crawlspace, or outdoors (as shown in Table 6-6). The regional estimate assumed that half were located in conditioned space and half in nonconditioned space. The RSDP Study, which may be an indicator of current construction trends, has very few unheated basements. That fraction of hot 
TABLE 6-2

Mean Hot Water and Normal Tank Location Temperatures

\begin{tabular}{|c|c|c|c|c|c|c|c|}
\hline \multirow[b]{2}{*}{ Sample } & \multicolumn{3}{|c|}{$\begin{array}{l}\text { Hot Water Tap } \\
\text { Temperature }\end{array}$} & \multicolumn{4}{|c|}{$\begin{array}{c}\text { Estimated Tank Location } \\
\text { Temperature }\end{array}$} \\
\hline & $\begin{array}{l}\text { Mean } \\
(\circ \mathrm{F})\end{array}$ & $\stackrel{n}{(-)}$ & $\begin{array}{c}\text { S.Dev. } \\
(\circ \mathrm{F})\end{array}$ & $\begin{array}{l}\text { Mean } \\
(\circ \mathrm{OF})\end{array}$ & $\stackrel{n}{(-)}$ & $\begin{array}{c}n \\
(\%)\end{array}$ & $\begin{array}{l}\text { S.Dev. } \\
(\circ \mathrm{F})\end{array}$ \\
\hline A11 ELCAP & 137 & 348 & 14 & 63 & 354 & 100 & 7 \\
\hline $\begin{array}{l}\text { Base-A11 } \\
\text {-Occupied Zone } \\
\text { - Heated Basement } \\
\text {-Daylight Basement } \\
\text { - Unheated Basement } \\
\text { - Porch/Sunspace } \\
\text { - Crawlspace } \\
\text { - Garage } \\
\text {-Outdoors }\end{array}$ & $\begin{array}{l}138 \\
138 \\
140 \\
139 \\
141 \\
135 \\
125 \\
139 \\
124\end{array}$ & $\begin{array}{r}224 \\
76 \\
53 \\
10 \\
29 \\
2 \\
13 \\
37 \\
1\end{array}$ & $\begin{array}{r}15 \\
12 \\
12 \\
11 \\
9 \\
7 \\
39 \\
12 \\
0\end{array}$ & $\begin{array}{l}62 \\
70 \\
61 \\
61 \\
56 \\
57 \\
59 \\
54 \\
52\end{array}$ & $\begin{array}{r}223 \\
75 \\
52 \\
10 \\
34 \\
3 \\
14 \\
34 \\
1\end{array}$ & $\begin{array}{r}34 \\
23 \\
4 \\
15 \\
1 \\
6 \\
15 \\
<1\end{array}$ & $\begin{array}{l}7 \\
4 \\
3 \\
2 \\
5 \\
3 \\
2 \\
3 \\
0\end{array}$ \\
\hline $\begin{array}{l}\text { RSDP-A1l } \\
\text {-Occupied Zone } \\
\text { - Heated Basement } \\
\text {-Dayl ight Basement } \\
\text { - Unheated Basement } \\
\text { - Porch/Sunspace } \\
\text { - Crawlspace } \\
\text { - Garage } \\
\text {-Outdoors }\end{array}$ & $\begin{array}{l}131 \\
134 \\
129 \\
128 \\
138 \\
130 \\
127 \\
129 \\
-\end{array}$ & $\begin{array}{r}84 \\
38 \\
19 \\
4 \\
3 \\
1 \\
6 \\
13 \\
0\end{array}$ & $\begin{array}{r}10 \\
10 \\
11 \\
12 \\
3 \\
0 \\
5 \\
10\end{array}$ & $\begin{array}{l}65 \\
71 \\
63 \\
64 \\
56 \\
63 \\
53 \\
54 \\
-\end{array}$ & $\begin{array}{r}90 \\
43 \\
19 \\
4 \\
3 \\
1 \\
6 \\
14 \\
0\end{array}$ & $\begin{array}{r}- \\
48 \\
21 \\
4 \\
3 \\
1 \\
7 \\
15 \\
0\end{array}$ & $\begin{array}{l}8 \\
3 \\
3 \\
1 \\
5 \\
0 \\
3 \\
2 \\
-\end{array}$ \\
\hline Other-All & 141 & 40 & 10 & 64 & 41 & - & 8 \\
\hline
\end{tabular}

water tanks located in unheated basements in the Base Study appears, for the RSDP study, to have been installed in primary occupied zones, thereby raising the fraction in occupied zones to $48 \%$.

Except for occupied zones, tank location temperatures are estimated, not measured, as described in Appendix $C$. Nevertheless, they should reasonably approximate the actual air temperatures at the tank locations. For the Base Study, the tank location temperature averages $62 \circ \mathrm{F}$, ranging from $70^{\circ} \mathrm{F}$ in the occupied zones to $52^{\circ} \mathrm{F}$ for the lone tank located outdoors. Similar 
temperatures are indicated for the RSDP study, although the overall average is higher due to the shift in tank locations.

Thus, the temperature difference driving standby heat loss is about $76^{\circ} \mathrm{F}$ in the Base Study, $66^{\circ} \mathrm{F}$ in the RSDP study, and $74^{\circ} \mathrm{F}$ for the ELCAP homes as a whole. The average temperature difference used to develop regional planning estimates for standby losses is $70^{\circ} \mathrm{F}$ and $80^{\circ} \mathrm{F}$ for demand. The temperature differences in the ELCAP homes clearly do not explain why regional planning estimates are higher than the ELCAP standby load estimates. The differences are more likely due to conservation measures already installed in the ELCAP Base Study.

\subsection{TANK EF-FACTOR ESTIMATES}

The 1977 federal appliance efficiency standard for water heaters mandates a test procedure for hot water tanks that includes an efficiency factor (EF-factor) derived from a 48-hour test of standby loads (Fanney 1990). The EF-factor for electric tanks is equivalent to the ratio of the daily typical residential hot water demand $10 a d$ (64.3 gallons per day at a $90 \circ \mathrm{F}$ temperature difference between the hot and cold water) to the total daily load, including the heat loss. The heat loss test uses a $90 \circ \mathrm{F}$ difference between the hot water temperature and the temperature of the air surrounding the tank.

The EF-factor for electric tanks can be simply expressed as

$$
E F=\text { Std. Demand Load / (Std. Demand Load + Std. Standby Load) }
$$

Substituting Equations (3-1) and (3-2) for the standby and demand loads, and using the density and specific heat of water given in Equation (3-1), the EF-factor can be expressed as

$$
E F=\frac{47,735 \mathrm{Btu} / \text { day }}{\left[47,735 \mathrm{Btu} / \mathrm{day}+\mathrm{UA}\left(90^{\circ} \mathrm{F}\right)(24 \mathrm{hr} / \text { day })\right]}
$$


where the UA is the tank heat loss coefficient in units of Btu/hr- ${ }^{\circ} \mathrm{F}$. The UA of the hot water tanks in ELCAP is simple to calculate from the standby loads estimated from the data. Simply re-arranging Equation (3-2)

$$
U A=Q_{\text {standby }} /\left(T_{\text {hot }}-T_{\text {local }}\right)
$$

where in this case $Q_{\text {standby }}$ is the standby load estimate, $T_{\text {hot }}$ is the hot water tap temperature, and $T_{\text {local }}$ is the estimated tank location temperature. Table F-4 of Appendix $F$ summarizes the UAs derived in this analysis.

The EF-factors estimated for the tanks are shown in Table 6-3. The average for the Base Study and the ELCAP homes as a whole is 0.79 , and for the RSDP study it is 0.78 . This suggests that the hot water tanks in the RSDP study, most likely purchased in 1983, have heat loss rates as high as those in the Base Study. Note that this calculation includes average conservation measure on the water heater (e.g., wraps). Most calculations of EF-factor are based on data reported by the manufacturer for the tank itself.

\subsection{EFFECTIVE TANK R-VALUE ESTIMATES}

The EF-factors in Table 6-3 do not account for differences in tank sizes, while computing an effective R-value does take this into account. Because, by definition, $R$-values are the reciprocal of the $U$-value, the effective R-value (averaged over the tank surface area, including the pipe losses) is given by

$$
\text { R-effective }=A_{\text {tank }} / U A
$$

where $A_{\text {tank }}$ is the tank surface area.

The surface areas of the tanks are not known, but the nominal tank volume (in gallons) was recorded as part of the onsite inspection of each house. Tank dimensions from several model 1 ines from two major manufacturers were examined to estimate the relationship between tank volume and surface area. Dimensions for cylindrical tanks were used. These data are summarized in Tables G-1 and G-2 of Appendix G. The actual tank surface area is used 
TABLE 6-3

Tank EF-Factor Estimates

\begin{tabular}{|c|c|c|c|c|c|c|}
\hline \multirow[b]{2}{*}{ Sample } & \multicolumn{3}{|c|}{ Calibration Homes } & \multicolumn{3}{|c|}{ Filled } \\
\hline & Mean & $n$ & S.Dev. & Mean & $n$ & S.Dev. \\
\hline A11 ELCAP & 0.81 & 104 & 0.10 & 0.79 & 321 & 0.08 \\
\hline $\begin{array}{l}\text { Base-A11 } \\
\text {-0ccupied Zone } \\
\text { - Heated Basement } \\
\text {-Daylight Basement } \\
\text { - Unheated Basement } \\
\text { - Porch/Sunspace } \\
\text {-Crawlspace } \\
\text {-Garage } \\
\text {-Outdoors }\end{array}$ & $\begin{array}{l}0.82 \\
0.79 \\
0.82 \\
0.79 \\
0.83 \\
- \\
0.99 \\
0.82 \\
-\end{array}$ & $\begin{array}{r}63 \\
22 \\
13 \\
4 \\
10 \\
0 \\
5 \\
9 \\
0\end{array}$ & $\begin{array}{l}0.12 \\
0.05 \\
0.05 \\
0.04 \\
0.04 \\
- \\
0.41 \\
0.04 \\
-\end{array}$ & $\begin{array}{l}0.79 \\
0.77 \\
0.80 \\
0.76 \\
0.81 \\
0.78 \\
0.85 \\
0.80 \\
0.85\end{array}$ & $\begin{array}{r}203 \\
67 \\
44 \\
7 \\
30 \\
3 \\
13 \\
35 \\
1\end{array}$ & $\begin{array}{l}0.09 \\
0.07 \\
0.06 \\
0.06 \\
0.04 \\
0.06 \\
0.27 \\
0.07 \\
0.0\end{array}$ \\
\hline $\begin{array}{l}\text { RSDP-A1l } \\
\text {-Occupied Zone } \\
\text { - Heated Basement } \\
\text {-Daylight Basement } \\
\text { - Unheated Basement } \\
\text { - Porch/Sunspace } \\
\text { - Crawlspace } \\
\text { - Garage } \\
\text {-Outdoors }\end{array}$ & $\begin{array}{l}0.79 \\
0.78 \\
0.78 \\
0.75 \\
- \\
- \\
0.83 \\
0.81 \\
-\end{array}$ & $\begin{array}{r}30 \\
16 \\
5 \\
1 \\
0 \\
0 \\
3 \\
5 \\
0\end{array}$ & $\begin{array}{l}0.04 \\
0.04 \\
0.06 \\
0.00 \\
- \\
- \\
0.01 \\
0.04 \\
-\end{array}$ & $\begin{array}{c}0.78 \\
0.76 \\
0.77 \\
0.77 \\
0.79 \\
- \\
0.81 \\
0.80 \\
-\end{array}$ & $\begin{array}{r}81 \\
40 \\
15 \\
4 \\
3 \\
0 \\
5 \\
14 \\
0\end{array}$ & $\begin{array}{l}0.05 \\
0.05 \\
0.06 \\
0.02 \\
0.03 \\
- \\
0.04 \\
0.05 \\
-\end{array}$ \\
\hline Other-All & 0.79 & 11 & 0.04 & 0.78 & 37 & 0.37 \\
\hline
\end{tabular}

here, not surface area of the jacket that surrounds the tank insulation. The average surface areas of the models analyzed for various standard tank sizes are included in Table G-5 of Appendix G.

Average effective R-values estimated for the ELCAP hot water tanks are shown in Table 6-4. Effective R-values for the Base Study average around R-4.4. The RSUP study averages are slightly lower, about $R-4.0$. This indicates that performance of the RSDP tanks is not degraded by their being larger, on average, than those in the Base Study. Again, note that these $R$ values include the effect of any conservation measures installed. 
Table 6-4

Effective R-Value Estimates

\begin{tabular}{|c|c|c|c|c|c|c|}
\hline \multirow[b]{2}{*}{ Sample } & \multicolumn{3}{|c|}{ Calibration Homes } & \multicolumn{3}{|c|}{ Filled } \\
\hline & Mean & $n$ & S.Dev. & Mean & $n$ & S.Dev. \\
\hline A11 ELCAP & 4.36 & 90 & 1.51 & 4.25 & 271 & 1.66 \\
\hline $\begin{array}{l}\text { Base-All } \\
\text { - Occupied Zone } \\
\text { - Heated Basement } \\
\text {-Daylight Basement } \\
\text { - Unheated Basement } \\
\text { - Porch/Sunspace } \\
\text {-Crawlspace } \\
\text { - Garage } \\
\text {-Outdoors }\end{array}$ & $\begin{array}{l}4.58 \\
4.29 \\
5.09 \\
3.74 \\
5.21 \\
- \\
3.55 \\
4.93 \\
-\end{array}$ & $\begin{array}{r}52 \\
19 \\
12 \\
3 \\
8 \\
0 \\
5 \\
5 \\
0\end{array}$ & $\begin{array}{l}1.77 \\
1.35 \\
1.68 \\
0.85 \\
1.50 \\
- \\
3.78 \\
1.29 \\
-\end{array}$ & $\begin{array}{l}4.36 \\
3.73 \\
4.75 \\
3.80 \\
4.68 \\
3.61 \\
3.60 \\
5.01 \\
5.86\end{array}$ & $\begin{array}{r}162 \\
53 \\
40 \\
5 \\
24 \\
2 \\
9 \\
26 \\
1\end{array}$ & $\begin{array}{l}1.78 \\
1.26 \\
1.99 \\
0.88 \\
1.57 \\
1.37 \\
2.82 \\
1.87 \\
0.00\end{array}$ \\
\hline $\begin{array}{l}\text { RSDP-All } \\
\text {-Occupied Zone } \\
\text { - Heated Basement } \\
\text { - Daylight Basement } \\
\text { - Unheated Basement } \\
\text { - Porch/Sunspace } \\
\text { - Crawlspace } \\
\text { - Garage } \\
\text {-Outdoors }\end{array}$ & $\begin{array}{c}4.10 \\
3.74 \\
4.00 \\
3.09 \\
- \\
- \\
5.06 \\
4.86 \\
-\end{array}$ & $\begin{array}{r}28 \\
14 \\
5 \\
1 \\
0 \\
0 \\
3 \\
5 \\
0\end{array}$ & $\begin{array}{l}1.05 \\
0.91 \\
1.31 \\
0.00 \\
- \\
- \\
0.52 \\
0.90 \\
-\end{array}$ & $\begin{array}{c}4.01 \\
3.74 \\
3.83 \\
3.89 \\
4.49 \\
- \\
4.56 \\
4.64 \\
-\end{array}$ & $\begin{array}{r}74 \\
36 \\
14 \\
3 \\
2 \\
0 \\
5 \\
14 \\
0\end{array}$ & $\begin{array}{c}1.15 \\
0.94 \\
1.37 \\
0.70 \\
1.67 \\
- \\
1.08 \\
1.30 \\
-\end{array}$ \\
\hline 0ther $-A 11$ & 3.99 & 10 & 0.79 & 4.26 & 35 & 1.99 \\
\hline
\end{tabular}

\subsection{NOMINAL TANK R-VALUE ESTIMATES}

Because many past estimates of energy use and savings from water heaters have been correlated to the tank's nominal $R$-value, it is useful to compute these values for the ELCAP sample (see Table 6-5). As shown by the data in Appendix $G$, manufacturers report $R$-values based on the thickness of the insulation around the sides of the tanks. Effective R-values are much lower because insulation around the top and bottom of the tank is generally somewhat thinner, even if polyurethane is used instead of fiberglass (which is easily crushed). The effective R-value of the tank walls is also slightly less because of the geometric effect of the cylindrical tank. Finally, effective $R$-values are reduced significantly by heat losses from the pipes connected to the tank. 
TABLE 6-5

Nominal R-Value Estimates

\begin{tabular}{|c|c|c|c|c|c|c|}
\hline \multirow[b]{2}{*}{ Sample } & \multicolumn{3}{|c|}{ Calibration Homes } & \multicolumn{3}{|c|}{ Filled } \\
\hline & Mean & $n$ & S.Dev. & Mean & $n$ & S.Dev. \\
\hline A11 ELCAP & 8.53 & 90 & 3.49 & 8.46 & 271 & 4.41 \\
\hline $\begin{array}{l}\text { Base-A11 } \\
\text {-Occupied Zone } \\
\text { - Heated Basement } \\
\text {-Daylight Basement } \\
\text {-Unheated Basement } \\
\text { - Porch/Sunspace } \\
\text {-Crawlspace } \\
\text { - Garage } \\
\text {-Outdoors }\end{array}$ & $\begin{array}{r}9.07 \\
8.40 \\
10.16 \\
7.07 \\
10.54 \\
- \\
7.13 \\
9.83 \\
-\end{array}$ & $\begin{array}{r}52 \\
19 \\
12 \\
3 \\
8 \\
0 \\
5 \\
5 \\
0\end{array}$ & $\begin{array}{l}4.10 \\
2.98 \\
4.56 \\
2.16 \\
4.51 \\
- \\
7.21 \\
2.98 \\
-\end{array}$ & $\begin{array}{r}8.79 \\
7.13 \\
9.86 \\
7.06 \\
9.51 \\
7.00 \\
7.11 \\
10.59 \\
11.18\end{array}$ & $\begin{array}{r}162 \\
53 \\
40 \\
5 \\
24 \\
2 \\
9 \\
26 \\
1\end{array}$ & $\begin{array}{l}4.70 \\
2.79 \\
5.79 \\
2.01 \\
4.58 \\
2.35 \\
5.51 \\
5.37 \\
0.00\end{array}$ \\
\hline $\begin{array}{l}\text { RSDP-All } \\
\text {-Occupied Zone } \\
\text { - Heated Basement } \\
\text {-Daylight Basement } \\
\text { - Unheated Basement } \\
\text { - Porch/Sunspace } \\
\text {-Crawl space } \\
\text { - Garage } \\
\text {-Outdoor }\end{array}$ & $\begin{array}{l}7.68 \\
6.84 \\
7.14 \\
6.35 \\
- \\
- \\
9.74 \\
9.62 \\
-\end{array}$ & $\begin{array}{r}28 \\
14 \\
5 \\
1 \\
0 \\
0 \\
3 \\
5 \\
0\end{array}$ & $\begin{array}{l}2.25 \\
1.86 \\
2.39 \\
0.00 \\
- \\
- \\
1.23 \\
2.31 \\
-\end{array}$ & $\begin{array}{c}7.54 \\
6.86 \\
7.01 \\
6.94 \\
8.25 \\
- \\
8.52 \\
9.49 \\
-\end{array}$ & $\begin{array}{r}74 \\
36 \\
14 \\
3 \\
2 \\
0 \\
5 \\
14 \\
0\end{array}$ & $\begin{array}{c}2.63 \\
2.00 \\
3.10 \\
0.91 \\
3.29 \\
- \\
2.69 \\
3.01 \\
-\end{array}$ \\
\hline Other-A11 & 8.08 & 10 & 2.40 & 8.84 & 35 & 5.67 \\
\hline
\end{tabular}

Also included in the data of Appendix $G$ are calculations of correction factors for the reduced end and bottom insulation in the manufacturers' tanks. Table G-5 indicates thai, on average, the top and bottom of the tanks have Rvalues of a little less than one-third that of the tank walls. This was determined by backing out the top and bottom losses based on

- EF-factors determined by testing each tank model for compliance with federal standards

- nominai R-values and tank wall surface areas 
- estimates of pipe losses from Bonneville laboratory tests by Ek and Auberg (1984).

These calculations are summarized in Appendix G.

One interesting finding is that EF-factors appear unreliable when they are 0.92 or greater. This occurs because the 48 -hour test used for the standards catches only a few ( 3 to 5) cycles for tanks that are this efficient. The arbitrary truncation of the test in the middle of the last cycle produces a random source of error, but with a bias that is exclusively toward producing higher EF-factors! Thus, EF-factors, as derived from the current testing procedure, may prove unreliable for resource planning purposes as tank efficiencies approach such high levels. A simple modification to the test would solve this problem: ending the test after a completed warmup event and adjusting for the time of the test that varies as a result.

Finally, the nominal R-values in Table 6-5 adjust for the presence of pipe insulation, thermal traps/anticonvection valves, and bottom boards. These adjustments are made on the basis of impacts estimated by laboratory testing conducted by Bonneville (EK and Auberg 1984). These calculations are summarized in Appendix $H$. Results of the nominal R-value calculations are shown in Table 6-5.

One incidental finding, discovered in the process of working with the laboratory test data, suggests that two of the tests produced all the largest outliers in the impact estimates (which are derived by subtracting the heat loss rates of two tests -- with and withcut a given conservation measure). Eliminating the results involved with these two tests cleared up the puzzling conclusion that the impacts of pipe loss reduction measures (insulation and traps) interact with the jacket loss reducing measures (initial insulation level, wraps, and bottom boards). This finding is highlighted in Appendix $H$. 


\subsection{CONSERVATION MEASURE IMPACTS}

To determine impacts of conservation measures that reduce standby loads, standby load estimates for homes with and without conservation measures were compared using a series of regression models. Four types of models were tried:

1) regression models of standby loads against a list of key explanatory variables including tank surface areas, tap temperature/tank location temperature differences, and conservation measures

2) regression models of standby loads against conservation measures listed in Table 6-6, multiplied by the product of their effective surface areas and the difference in hot water tap temperature and tank location temperature

3) regression models of tank heat loss coefficients (UAs) against conservation measures listed in Table $0-6$

4) regression models of tank $U$-values against the 1 ist of conservation measures in Table 6-6, divided by their equivalent surface areas.

The effective surface area for tank wraps and tanks with nominal $R$-values greater than $R-3$ is the tank surface area. The effective surface area for bottom boards is the tank bottom area (half the area of the ends of the tank), equal to $8.5 \%$ of the total surface area on average (see Table G-5 in Appendix G). The effective surface area for pipes is estimated as $3.79 \mathrm{ft}^{2}$ based on the laboratory tests of Ek and Auberg (1984). See Appendix $H$ for details.

\section{TABLE 6-6}

Conservation Measure Variables Used as Explanatory Variables in Standby Load Models

Conservation Measure

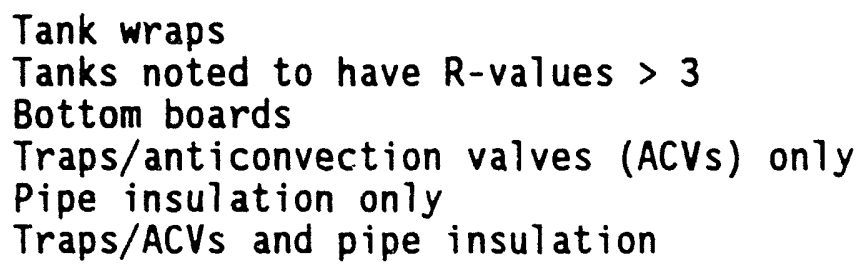


Only those homes with valid standby estimates and a complete set of explanatory variables were used in the models. The explanatory variables used in the regressions were eliminated in a stepwise procedure, dropping from each step the variable with the lowest T-statistic.

The results of constructing these models are relatively disappointing, explaining low fractions of the variance $\left(R^{2}\right.$ values of 0.10 and 1 ess). Nevertheless, some statistically meaningful coefficients are indicated by T-statistics near or above 2.0. The final results are summarized in Table 6-7. Generally, the only conservation measures shown to be statistically significant are tank wraps and bottom boards. The nonphysical form of the standby model clearly indicates that the surface areas and temperature differences explain significant variance. However, it is difficult to interpret.

The UA model coefficients for tank wraps and bottom boards appear to roughly confirm the laboratory impacts of Ek and Auberg (1984). The magnitude of the tank wrap savings $\left(0.97 \mathrm{Btu} / \mathrm{hr}-{ }^{\circ} \mathrm{F}\right)$ is approximately as the laboratory experiment indicates $\left(2.79 \mathrm{Btu} / \mathrm{hr}-{ }^{\circ} \mathrm{F}\right)$, if the benefit of tank wraps is discounted to reflect the sizeable fraction of wraps that only partially cover the tanks. The savings value for the bottom boards is remarkably close to the average of the laboratory test results $\left(0.36 \mathrm{Btu} / \mathrm{hr}-{ }^{\circ} \mathrm{F}\right)$. 
TABLE 6-7

Regression Model Results

Final Model Variable (units)

Coefficient Std. Error T-Statistic

Standby Load Model,

Nonphysical Form $\left(R^{2}=0.10, n=211\right)$

Intercept (avg.watts)

Tank wrap (avg.watts)

Surface area (avg.watts/ft ${ }^{2}$ )

$-1.85$

$-15.24$

3.98

Tap - avg. location temp. (avg.watts $/{ }^{\circ} F$ )

0.607

34.5

6.35

1.32

$-0.0537$

$-2.40$

3.01

0.209

2.90

Standby Load Mode],

Physical Form $\left(R^{2}=0.01, n=211\right)$

(No useful results)

UA Model $\left(R^{2}=0.05, n=228\right)$

Intercept (Btu/hr-oF)

6.65

$-0.971$

0.184

0.297

36.1

Tank wrap (Btu/hr-oF)

$-0.391$

0.446

$-3.27$

Bottom board (Btu/hr-oF)

0.446

$-0.877$

U-Value Model $\left(R^{2}=0.05, n=211\right)$

Intercept (Btu/hr- $\circ \mathrm{F}-\mathrm{ft}^{2}$ )

0.278

0.00772

36.0

Tank wrap (Btu/hr-oF-ft

$-0.0440$

0.0133

$-3.31$ 


\subsection{DEMAND LOADS}

This section examines the relationship of total hot water loads and hot water demand loads to the number and ages of occupants in the study homes. Demand loads are assumed to equal total load less the standby load estimate for each home. Section 7.1 describes how the numbers of occupants were averaged over time and presents average loads per occupant. Section 7.2 describes the use of three simple models to compare the relationship of number of occupants to the total hot water and hot water demand loads. Section 7.3 describes the results of models that also account for ages of the occupants.

\subsection{AVERAGE NUMBER OF OCCUPANTS}

The average number of occupants in each home during the metering period was obtained by averaging data from four annual occupant surveys. These surveys are documented in reports by Darwin et a1. 1986; Ivey and Alley 1987; Windell 1987 and a letter report to Bonneville. (a) Thus, the average number of occupants over the 4 years may not be an integer number if, for example, a child was born or the house was sold to new occupants. The number of occupants in each of four age groups surveyed (7ess than 6 years, 6 through 17 years, 18 through 65 years, and more than 65 years) were averaged similarly. Because the average annual hot water load data used are based on this same 4-year period, the average occupancy should roughly correspond to the average loads.

Total annual hot water loads for all homes in ELCAP and those in the Base Study are shown in Tables 7-1 and 7-2. Similarly, hot water demand loads obtained by subtracting standby estimates from the total hot water load, are shown in Tables 7-3 and 7-4. Sample sizes ( $n$ ) are lower in Tables 7-3 and 7-4 than in Tables 7-1 and 7-2 because demand estimates are derived from standby estimates, which were not available for all homes. The first column in each table is the nominal number of occupants in the home. A home was defined as

(a) A 1989 letter report to the Bonneville Power Administration from Pacific Northwest Laboratory, authors M. P. Hattrup and M. A. Halverson.

$$
7-1
$$


TABLE 7-1

ELCAP Hot Water Loads per Occupant

All Studies (kWh/yr)

Nom. Avg. Total Average No. of Occupants by Age

No. Total Load/

OcC. Load OCC. $<6 \quad 6-17 \quad 18-65>65 \quad$ A11

\begin{tabular}{rcccccccr}
\hline 1 & 2550 & 2239 & 0.00 & 0.00 & 0.54 & 0.60 & 1.15 & 28 \\
2 & 3540 & 1715 & 0.06 & 0.06 & 1.43 & 0.54 & 2.08 & 127 \\
3 & 5076 & 1715 & 0.37 & 0.30 & 2.26 & 0.06 & 2.98 & 57 \\
4 & 5443 & 1358 & 0.65 & 1.00 & 2.34 & 0.04 & 4.01 & 69 \\
5 & 6326 & 1277 & 0.75 & 1.94 & 2.30 & 0.00 & 4.96 & 25 \\
6 & 7346 & 1233 & 0.56 & 2.88 & 2.47 & 0.06 & 5.97 & 8 \\
7 & 5979 & 838 & 1.60 & 3.10 & 2.35 & 0.10 & 7.15 & 5 \\
8 & - & - & - & - & - & - & - & 0 \\
9 & - & - & - & - & - & - & - & 0 \\
10 & - & - & - & - & - & - & - & 0 \\
11 & 11250 & 1023 & 2.00 & 6.13 & 2.88 & 0.00 & 11.00 & 2 \\
\hline
\end{tabular}

TABLE 7-2

ELCAP Hot Water Loads per Occupant for the Base Study (kWh/yr)

Nom. Avg. Total Average No. of Occupants by Age

No. Total Load/

Occ. Load OcC. <6 $6-17 \quad 18-65>65$ All $n$

\begin{tabular}{ccccccccccc}
\hline 1 & 2633 & 2343 & 0.00 & 0.00 & 0.32 & 0.81 & 1.14 & 18 \\
2 & 3575 & 1746 & 0.03 & 0.04 & 1.31 & 0.68 & 2.06 & 82 \\
3 & 5321 & 1812 & 0.19 & 0.32 & 2.37 & 0.10 & 2.96 & 34 \\
4 & 5544 & 1390 & 0.49 & 1.06 & 2.38 & 0.05 & 4.00 & 44 \\
5 & 6032 & 1215 & 0.63 & 1.97 & 2.42 & 0.00 & 4.98 & 17 \\
6 & 7232 & 1216 & 0.46 & 2.89 & 2.54 & 0.07 & 5.96 & 7 \\
7 & 6930 & 955 & 1.00 & 3.58 & 2.58 & 0.17 & 7.33 & 3 \\
8 & - & - & - & - & - & - & - & 0 \\
9 & - & - & - & - & - & - & - & 0 \\
10 & - & - & - & - & - & - & - & 0 \\
11 & 11250 & 1023 & 2.00 & 6.13 & 2.88 & 0.00 & 11.00 & 2
\end{tabular}


TABLE 7-3

ELCAP Hot Water Demand Loads per Occupant All Studies (kWh/yr)

\begin{tabular}{cccccccccc}
\hline $\begin{array}{l}\text { Nom. } \\
\text { No. } \\
\text { Occ. }\end{array}$ & $\begin{array}{c}\text { Demand } \\
\text { Load }\end{array}$ & $\begin{array}{c}\text { Demand } \\
\text { Load/ }\end{array}$ Occ. & $<6$ & $6-17$ & $18-65$ & $>65$ & A 11 & $n$ \\
\hline 1 & 1350 & 1192 & 0.00 & 0.00 & 0.56 & 0.58 & 1.15 & 27 \\
2 & 2480 & 1197 & 0.07 & 0.06 & 1.44 & 0.52 & 2.09 & 115 \\
3 & 3922 & 1323 & 0.38 & 0.31 & 2.25 & 0.06 & 2.97 & 54 \\
4 & 4400 & 1098 & 0.69 & 0.93 & 2.35 & 0.04 & 4.01 & 58 \\
5 & 5312 & 1077 & 0.75 & 1.89 & 2.33 & 0.00 & 4.93 & 23 \\
6 & 5177 & 858 & 0.64 & 3.00 & 2.36 & 0.00 & 6.00 & 7 \\
7 & 4515 & 632 & 1.60 & 3.10 & 2.35 & 0.10 & 7.15 & 5 \\
8 & - & - & - & - & - & - & - & 0 \\
9 & - & - & - & - & - & - & - & 0 \\
10 & - & - & - & - & - & - & - & 0 \\
11 & 9939 & 904 & 2.00 & 6.13 & 2.88 & 0.00 & 11.00 & 2 \\
\hline
\end{tabular}

TABLE 7-4

ELCAP Hot Water Demand Loads per Occupant for the Base Study (kWh/yr)

\begin{tabular}{|c|c|c|c|c|c|c|c|c|}
\hline \multirow{2}{*}{$\begin{array}{l}\text { Nom. } \\
\text { No. } \\
\text { Occ. }\end{array}$} & \multirow{2}{*}{$\begin{array}{l}\text { Demand } \\
\text { Load }\end{array}$} & \multirow{2}{*}{$\begin{array}{c}\text { Demand } \\
\text { Load/ } \\
\text { Occ. }\end{array}$} & \multicolumn{6}{|c|}{ Average No. of Occupants by Age } \\
\hline & & & $<6$ & $6-17$ & $18-65$ & $>65$ & A11 & $n$ \\
\hline $\begin{array}{l}1 \\
2 \\
3 \\
4 \\
5 \\
6 \\
7\end{array}$ & $\begin{array}{l}1271 \\
2454 \\
4187 \\
4504 \\
5001 \\
5004 \\
5404\end{array}$ & $\begin{array}{r}1153 \\
1197 \\
1423 \\
1132 \\
1013 \\
828 \\
746\end{array}$ & $\begin{array}{l}0.00 \\
0.04 \\
0.20 \\
0.51 \\
0.62 \\
0.54 \\
1.00\end{array}$ & $\begin{array}{l}0.00 \\
0.04 \\
0.32 \\
1.01 \\
1.90 \\
3.04 \\
3.58\end{array}$ & $\begin{array}{l}0.34 \\
1.33 \\
2.35 \\
2.40 \\
2.47 \\
2.42 \\
2.58\end{array}$ & $\begin{array}{l}0.78 \\
0.66 \\
0.10 \\
0.05 \\
0.00 \\
0.00 \\
0.17\end{array}$ & $\begin{array}{l}1.14 \\
2.06 \\
2.96 \\
3.99 \\
4.94 \\
6.00 \\
7.33\end{array}$ & $\begin{array}{r}17 \\
74 \\
32 \\
37 \\
15 \\
6 \\
3\end{array}$ \\
\hline 8 & - & - & - & - & - & - & - & 0 \\
\hline 9 & . & - & - & - & - & . & - & 0 \\
\hline 10 & - & - & - & _- & - & - & - & 0 \\
\hline 11 & 9939 & 904 & 2.00 & 6.13 & 2.88 & 0.00 & 11.00 & 2 \\
\hline
\end{tabular}


belonging in the two-occupant group if it had more than 1.5 and less than 2.5 occupants, on average, over the metering period. The last column shows the number of homes used in the analysis for each grous.

The next two columns in each table are the average load and load per occupant for homes with the indicated nominal number of occupants. The next five columns show the average number of occupants in each of four age groups and the actual average total number of occupants in the homes. Note that the actual number of occupants for the homes with one nominal occupant averages 1.15 , and for two nominal occupants the average is 2.08. The average load per occupant was obtained by dividing the average load by the actual (not nominal) average number of occupants.

A strong relationship also exists between number of occupants and age groups. One-occufant homes are about equally likely to have an occupant over 65 years old as they are a younger adult. People older than 65 represent about $25 \%$ of all occupants in two-occupant homes, but they represent only a very small fraction of the occupants in homes with more than two occupants. The number of children per home shows a near opposite pattern, rising rapidly (from near zero) as the number of occupants increases above two.

As shown in Tables 7-1 and 7-2, as the number of occupants increases, the total hot water load per occupant decreases because the standby portion of the load is attributed to and averaged among an increasing number of occupants.

The relationship of hot water demand load to the number of occupants is more clearly illustrated by Tables 7-3 and 7-4, which summarize only the estimated demand loads. Here the demand load per occupant is fairly constant for the first two occupants, is larger for the third occupant, and then falls off rapidly for additional occupants. Because hot water demand is generally considered proportional to the number of occupants, this is somewhat surprising. This effect was previously noted by Bavir (1981). 
In homes having more than two occupants, an increasing fraction of the occupants are children, while the number of adults (ages 18-65) remains steady at about 2.3 per housenold. This suggests that shifts in ages as number of occupants increases may account for some of the irregularities in the tables. This is investigated further in a subsequent subsection.

\subsection{MODELS OF TOTAL HOT WATER LOADS}

Figure 7-1 plots the total annual electricity consumption for water heating for each home analyzed against the average number of occupants. These data were used to develop three models used to estimate total hot water load as a function of number of occupants. These three models ar illustrated in Figure 7-1. The linear model assumes the load is a linear function of the number of occupants

$$
\text { Load }=a+b \text { (no. occupants) }
$$

Figure 7-1

Total Hot Water Load by Number of Occupants

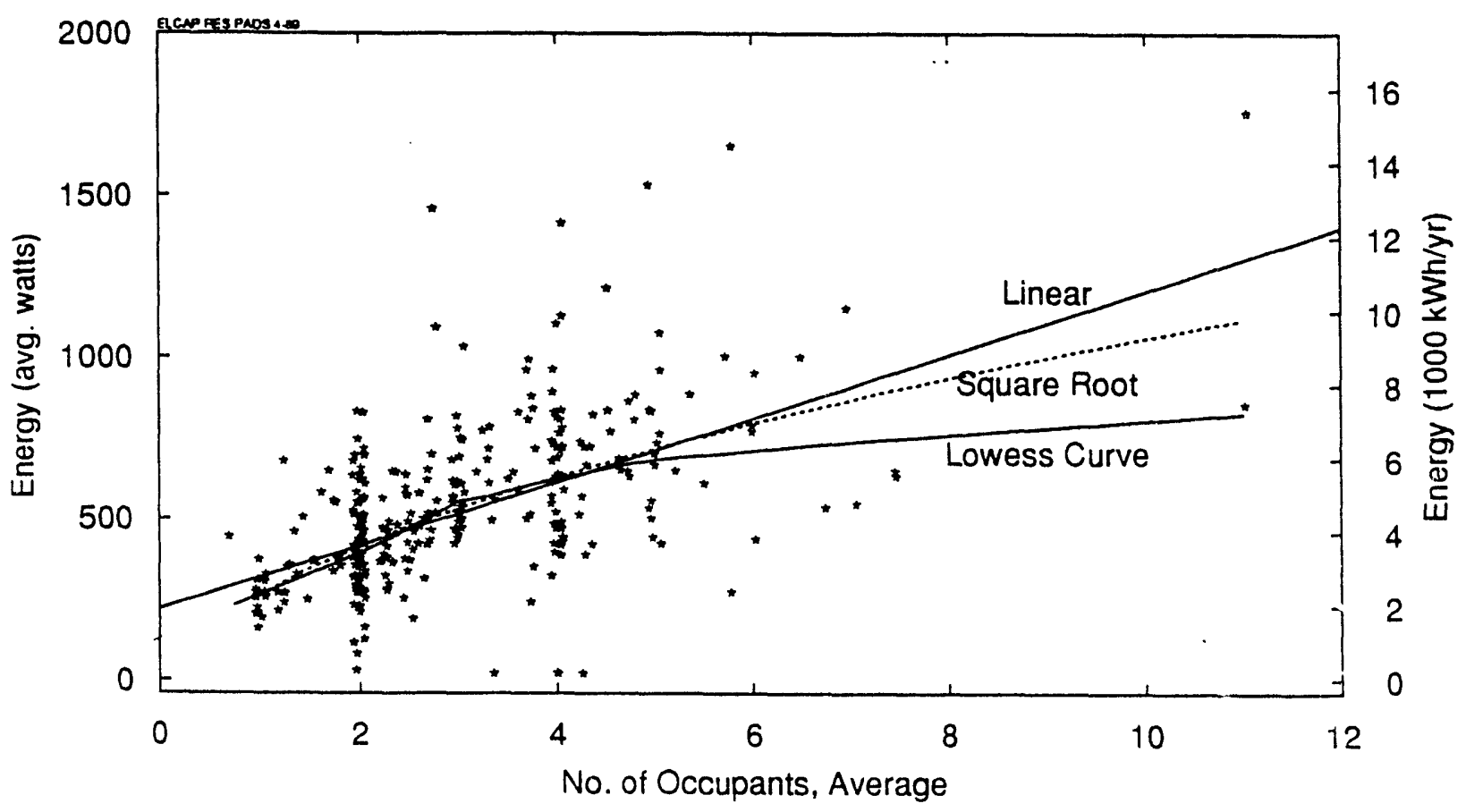


The linear model is determined based on a least-squares regression, with the results shown in Table 7-5. Note in Table 7-5 that the model has a y-axis intercept of $1917 \mathrm{kWh} / \mathrm{yr}$. The intercept is an estimate of the hot water load for zero occupants, and by definition should be equal to the standby load. However, it is much higher than the standby loads estimated in this analysis, as described in Section 6 (1162 kWh/yr for all REMP homes analyzed). It is important to note that the intercept for a linear model is the basis for the standby estimates obtained from previous regional studies of metered hot water loads. The high intercept presumably results from the 1 inear model not accounting properly for reduced consumption per occupant as the number of occupants becomes larger. This suggests that estimates obtained in this manner are not accurate for both the standby load and demand load per occupant.

The square root model attempts to account for this effect by modeling hot water loads using the square root of the number of occupants as the independent variable

$$
\text { Load }=a+b \text { (no. occupants) } 1 / 2
$$

TABLE 7-5

Regression Models of Total Hot Water Loads

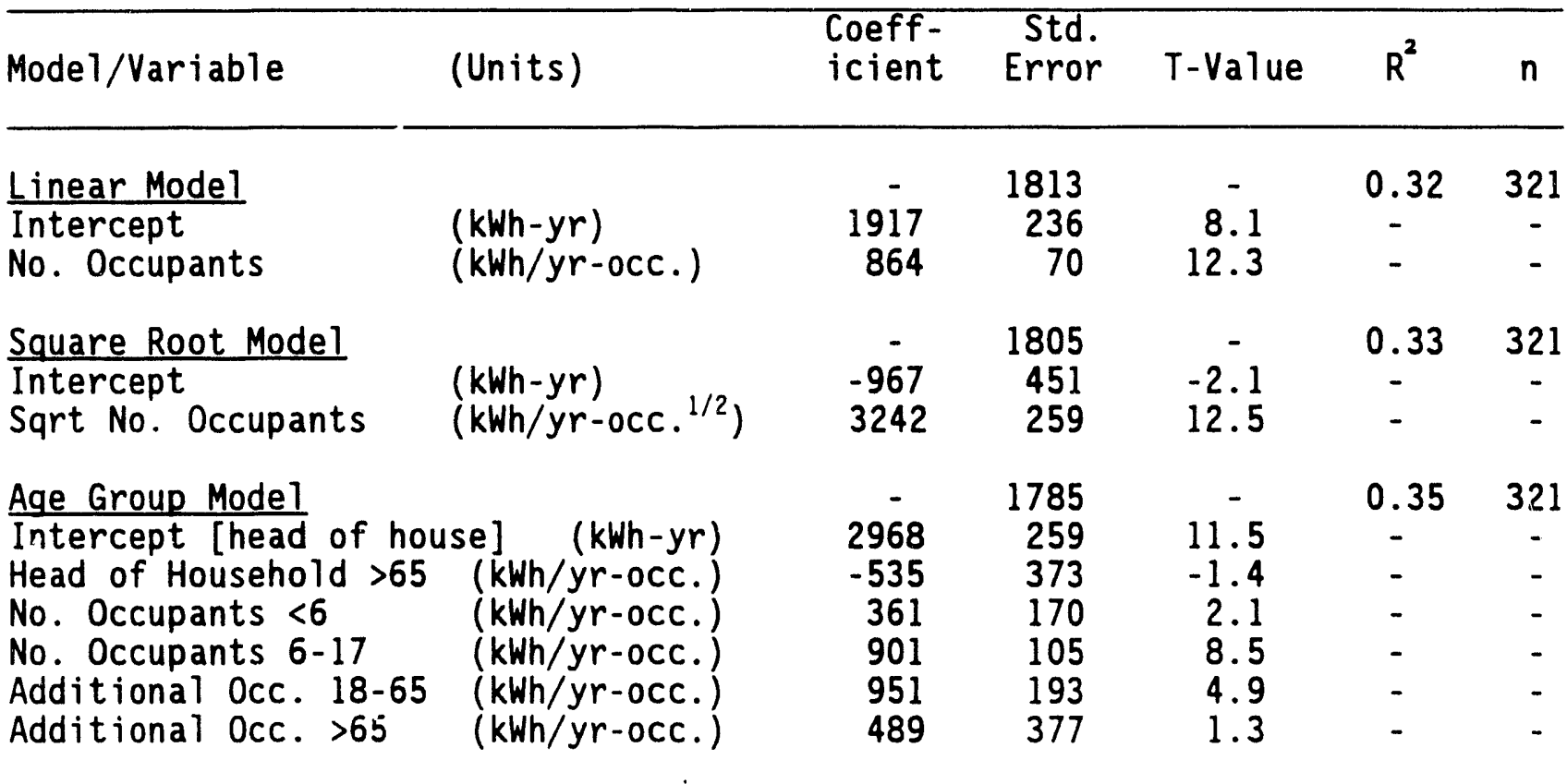


This model is also illustrated in Figure 7-1, and the regression results are shown in Table 7-5. Neither the linear model nor the square root model explains large fractions of the variance $\left(R^{2}\right.$ equal to 0.32 and 0.33 , respectively). The square root model has a negative intercept $(-110$ average watts or $-967 \mathrm{kWh} / \mathrm{yr})$, clearly not a valid standby load estimate.

Figure 7-1 shows a lowess curve fit to the data. A lowess curve is a set of weighted least squares regression line segments fit to a series of windows of data and can be thought of as a series of medians of adjacent, overlapping windows of data. This curve-fitting technique is used because it is nonparametric. That is, it does not assume an a priori mathematical relationship between the load and the number of occupants. Note that the lowess curve indicates a marked decrease in consumption per occupant as the number of occupants increases and is somewhat similar in shape to the square root model for homes with less than six occupants. This suggests that the square root model may have some value in modeling the reduced consumption by additional occupants. Extrapolating the lowess curve to a $y$-axis intercept provides a standby estimate of $1100 \mathrm{kWh} / \mathrm{yr}$, which is within $6 \%$ of the standby estimate obtained in this analysis (see Section 6 ).

As noted above, the ages of the occupants appear to be an important factor in determining water heating energy consumption. To investigate this further, an age group model was constructed that uses the number of occupants in four age categories (less than 6 years, 6 to 17 years, 18 to 65 years, and more than 65 years) as the explanatory variables. In this age group model, the first adult occupant 18 to 65 years was considered as head of the household and was included in the intercept. If the home had no occupants 18 to 65 years, meaning the head of household was older than 65 , a conditional variable (set to one for true, zero for false) indicating this situation was created for each home. This model has the form

$$
\begin{aligned}
\text { Load }=a+ & b \text { (head of household >65) }+ \\
& c(\text { no. occupants }<6)+ \\
& d \text { (no. occupants } 6 \text { to 17) }+ \\
& \text { e (no. occupants 18 to 65) }+ \\
& d(\text { no. occupants }>65)
\end{aligned}
$$


Results of the age group mode? regression ars al so shown in Table 7-5. The T-statistics for the age groups are all above 2.0 , except for those occupants older than 65 . This indicates the age group variables are statistically significant. The $R^{2}$ for this model $(0.35)$ is a little higher than for the other models. Coefficients of the age group model will be discussed and interpreted further in the following subsection on demand load models.

\subsection{MODELS OF HOT WATER DEMAND LOAD ESTIMATES}

Forms of the linear, square root, and age group models discussed above can be used to predict demand load estimates instead of total hot water loads. Regression results for these models are provided in Table 7-6. Because the variability caused by the different standby loads at each home has been subtracted, demand models are expected to explain more variance than models of total hot water load. This is the case, as illustrated by the higher fraction of variance explained $\left(R^{2}\right)$ of the models in Table 7-6 compared to the total load models in Table 7-5. The $R^{2}$ for each model showed modest increases in the range of 0.05 to 0.06 .

TABLE 7-6

Regression Models of Hot Water Demand Loads

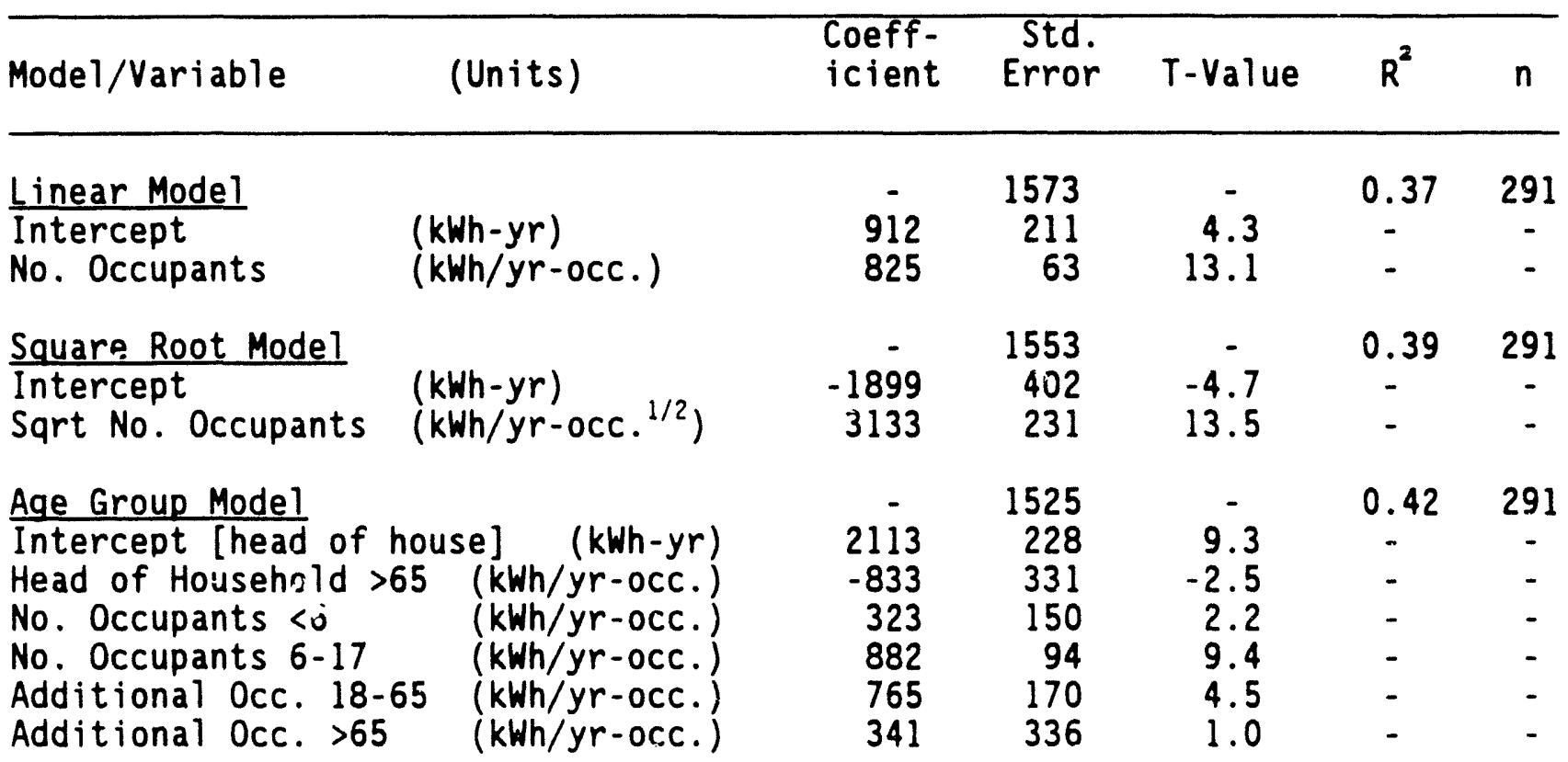


It is important to note that the intercept for the linear model is still significant and fairly large $(912 \mathrm{kWh} / \mathrm{yr})$, while the demalid load imposed by each additional occupant is $825 \mathrm{kWh} / \mathrm{yr}$. This supports the conclusion that there is residual demand for hot water to operate a home that is independent of the number of occupants, or that hot water demand by additional occupants after the first is reduced. This residual demand may represent basic household practices, suggesting that in single-occupant households dishes and clothes may be washed before full loads are accumulated.

If an average of 2.5 occupants per home is assumed typical, using the liner model, the estimated average demand load per occupant is 1191 kWh/yr-occupant. Using the Council's assumption of an $80 \circ \mathrm{F}$ temperature difference between the cold inlet water and the hot water, this average demand load is equivalent to a consumption rate of 17 gallons/day-occupant. This is very close to the general rule of thumb of 20 gallons/day-occupant used for sizing residential solar water heating systems (Solar Energy Applications Laboratory 1977) and the 18.4 gallons/day-occupant estimate obtained by Reese and Wall (1981).

The age group model of demand loads is also shown in Table 7-6. Again, this model has the highest $R^{2}$, and the T-statistics indica',e that the coefficients for all age groups (with the exception of additional occupants over 65) are statistically significant. The intercept accounts for the average load associated with the first adult occupant (referred to as head of household). Thus, the model implicitly includes the household residual demand load not attributable to additional occupants. The age group model produces an estimated demand load of $2113 \mathrm{kWh} / \mathrm{yr}$ for the head of household, compared with an estimated $1737 \mathrm{kWh} / \mathrm{yr}$ (intercept. plus one occupant) from the linear model for a single occupant. This difference of about $400 \mathrm{kWh} / \mathrm{yr}$ may reflect bias introduced in the linear model estimate because of relatively high numbers of occupants older than 65 years in homes with $c$ a or two occupants. The model suggests that occupants under 6 and over 65 years use much less hot water than occupants of other age groups. Also, children 6 through 17 years appear to consume $15 \%$ more hot water on average than adults 18 tirrough 65 years. 
The age group model, in addition to explaining the largest variance of any of the models tried, also provides an interpretation for the reduced level of demand by additional occupants. It demonstrates that, on the average, an adult head of household (18 through 65 years) consumes more than 2.5 times as much hot water as a second similar adult. Also, as the number of occupants in a home increases, the likelihood of children under 6 years increases (as shown in Table 7-1), and because hot water consumption associated with them is about $50 \%$ that of an adult 18 to 65 years old, they further lower the average demand per occupant for households with large numbers of occupants. Finally, a significant number of homes are occupied by one or two persons over 65 years (See Table 7-1). These homes have a very low hot water demand on average, and the presence of these homes in the sample tends to cause the intercept of the inear demand model to be low. All three of these effects combine to form the pattern of hot water demand loads seen in Tables 7-3 and 7-4.

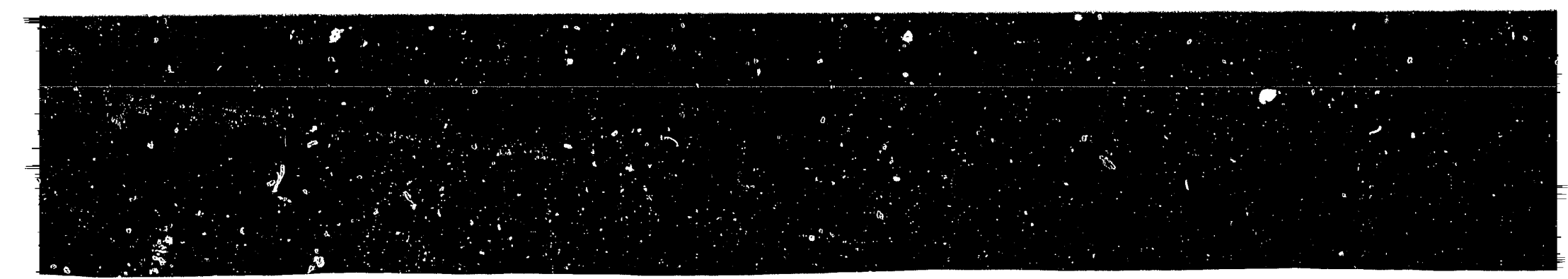




\subsection{STANDBY AND DEMAND EFFECTS ON LOAD SHAPE AND SEASONAL COMSUMPTION}

This section briefly discusses the relative importance of demand and standby loads in determining the hourly hot water load shape and the seasonal variation in hot water energy consumption.

To put hot water standby and demand loads in perspective, Figure 8-1 shows the average total hot water load shape for the ELCAP Base Study reported by Pratt et al. 1989. Also shown is the average hot wat ' standby load for the ELCAP Base Study. Although some seasonal variation in the standby load is expected on a theoretical basis, it is likely to be small arid is neglected here. Results of a study by Hanford et al. (1985) further support this assumption. The difference between the total load and the standby load is the demand load, which varies seasonally by about $30 \%$ and accounts for about twothirds of average total household hot water consumption.

\section{Figure 8-1}

Average Total Hot Water and Standby Monthly Loads for the Base Study

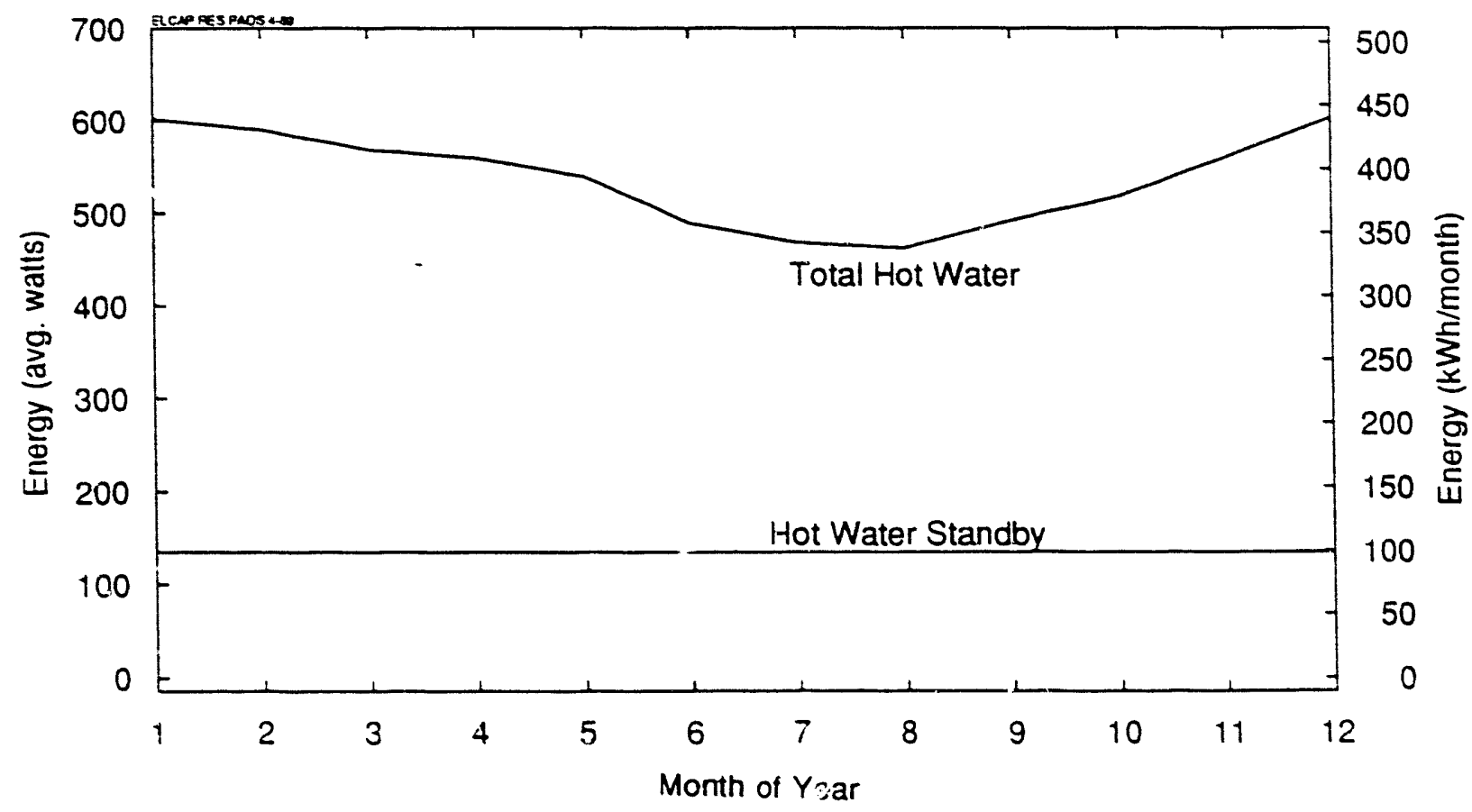


Because most water heating conservation measures and standards impact standby loads, in the future, seasonal variation of residential water heating loads is likely to increase (in percentage terms). As illustrated by the example in Figure 8-1, if standby loads were effectively eliminated, the remaining loads would consist solely of demand loads, resulting in a larger seasonal variation. This may have important consequences to those involved in planning intra-regional power sales.

An analogous situation occurs for average load shape, as shown in Figure 8-2. Again, the total load shape from Pratt et al. (1989) for the ELCAP Base Study is superimposed on the estimated standby load. Clearly, reducing the standby loads through programs and standards will result in lower peak loads. At the same time, however, the load factor for hot water loads (the ratio of the average load to the peak load) will be reduced, resulting in a "peakier" hot water load shape as these standards and programs are implemented. This has important consequences for utility systems that experience significant variations in costs for generating power during peak and off-peak periods.

Figure 8-2

Average Total Hot Water and Standby Load Profiles for the Base Study

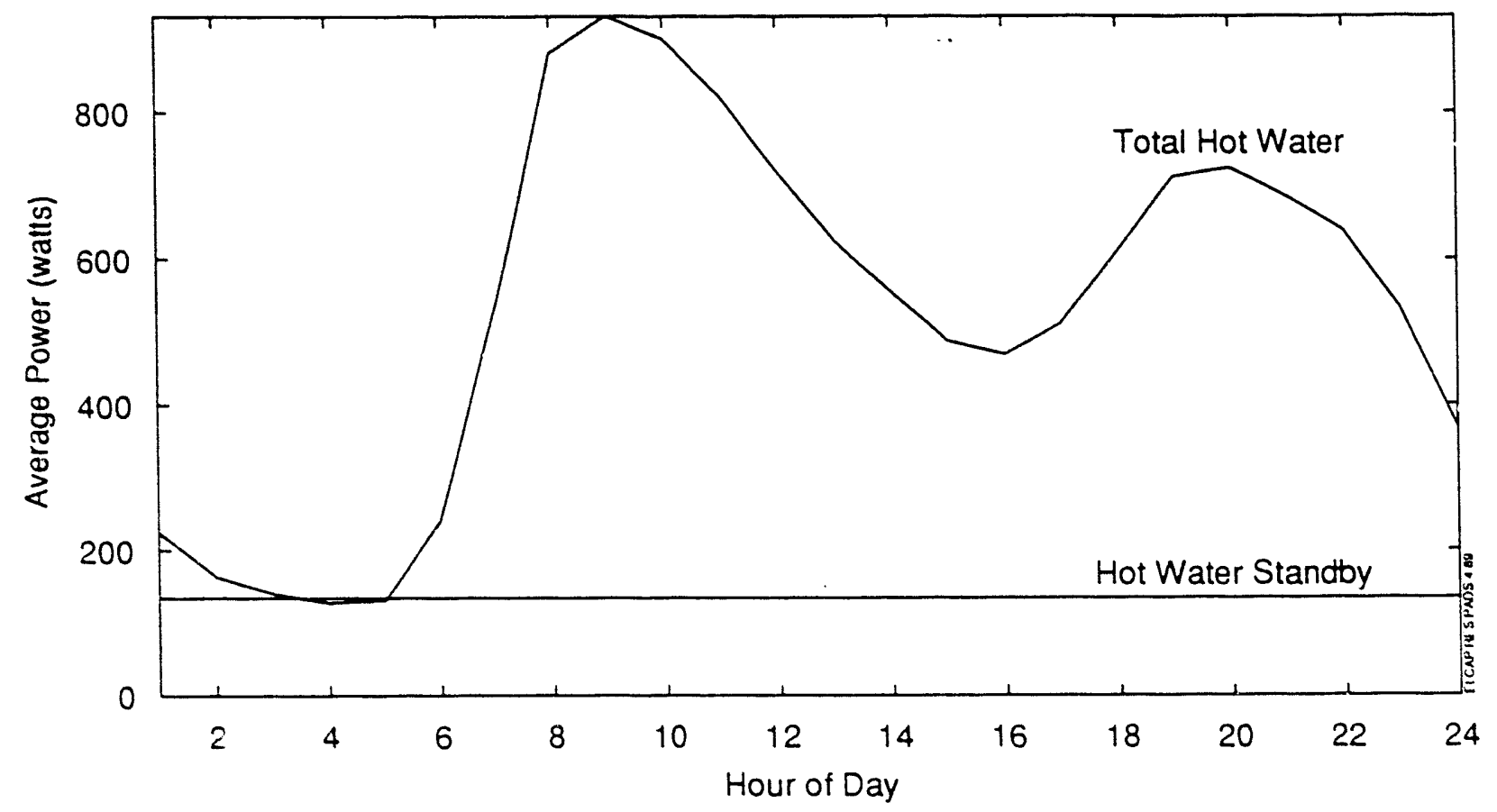


Finally, note that in Figure 8-2 the average load at 4 a.m. and $5 \mathrm{a} . \mathrm{m}$. almost equals the standby load estimate obtained by analyzing time series data from individual homes. This is not surprising, because few occupants use hot water during these hours, and any residual demand loads from tanks partially depleted by late evening "handwashing events" have largely been met by a subsequent tank warmup event. Such information supports standby estimates obtained in this analysis and suggests a simple alternative methodolugy for estimating standby loads from average load shapes for groups of buildings, and perhaps individual buildings as well. 


\subsection{REFERENCES}

Barvir E. J., L. G. Doak, R. E. Waterman, and C. Gervasio. 1981. "Hourly Use Profiles for Solar Domestic Hot K'ater Heaters in the National Solar Data Network." Solar Engineering. Vitro Laboratories Division, Silver Spring, Maryl and.

Bonneville Power Administration, 1986. Procedures Manual for ELCAP Residential Building Characteristics Survey. DOE/BP-13795-9, Bonneville Power Administration, Portland, Oregon.

Bonneville ?isver Administration. 1990. Draft 1990 Conservation Resources Suppi. Document (Technical Documentation). Bonneville Power Administration, Portiand, Oregon.

Darwin, R. F., D. L. Ivey, M. S. Klan, S. A. Shankle, and B. L. Mohler. 1986. Pacific Northwest Residential Energy Survey: 1985 Residential Occupant Survey -Telephone. DOE/BP-13795-15, Bonneville Power Administation, Por'tiand, Oregon.

Ek, C. W. 1982. The Effect of Electric Water Heater Tank Insulation Modifications and Water Pipe Insulation on Standby Power Consumption. Laboratory Report ERGH-82-35, Bonneville Power Administration, Portland, Oregon.

Ek, C. W. and C. D. Auberg. 1984. "Electric Water Heater Standby Losses: Comparison of Conservation Strategies and Their Energy Savings." In Proceedings of the 1984 American Council for an Energy Efficient Economy Summer Study on Buildings. American Council for an Energy Efficient Economy, Washington, D.C.

Fanney, A. H. 1990. "The Measured Performance of Residential Water Heaters Using Existing and Proposed Department of Energy Test Procedures." ASHRAE Transactions 1990, V. 96, Pt. 1. Americal: Society of Heating, Refrigerating, and Air-Conditioning Engineers, Inc., Atlanca, Georgia.

Federal Register. 1977. Vol 42, No. 192, pp. 54109-54119. October 4, 1977.

Hanford, J., M. Kennedy, M. J. DeLaHunt, and L. Palmiter. 1985. Heat Pump Water Heater Filed Test (Draft Final Report). Ecotope, Seattle, Washington.

Ivey, D. L. and P. K. Alley. 1987. 1986 Residential Occupant Survey. PNL-6138, Pacific Northwest Laboratory, Richland, Washington.

Natural Resources Defense Counci1. 1982. A Model Electric Power and Conservation Plan for the Pacific Northwest. Natural Resources Defense Council, Washington, D.C. 
Northwest Power Planning Council. 1991. Technical Appendix to Conservation Supply for the 1990 Power Plan. Northwest Power Planning Council, Portland, Oregon.

Parker, G. B., E. W. Pearson, and W. F. Sandusky, 1985. The Residential Pilot Study. DOE./BP/13795-\%, Ronneville Power Administration, Portland, Oregon.

Pratt, R. G., G. C. Conner, E. E. Richman, K. G. Ritland, W. F. Sandusky, and M. E. Taylor. 1989. Description of Electric Energy Use in Single-Family Residences in the Pacific Northwest. DOE/BP-13795-21, Bonneville Power Administration, Portland, Oregon.

Reese, S. P. and H. A. Wall. 1981. Residential Electric Water Heater Conservation Potential. Seattle City Light, Seattle, Washington.

Solar Energy Applications Laboratory. 1977. Solar Heating and Cooling of Residential Buildings -- Design of Systems. Colorado State University, Fort Colitins, Colorado.

Taylor, M. E., K. G. Ritland, and R. G. Pratt. 1991. Hot Water Electric Energy Use in Single-Family Residences in the Pacific Northwest. DOE/BP-13795-27, Bonneville Power Administration, Portland, Oregon.

U.S. Department of Energy. 1989. Technical Support Document: Erergy Conservation Standards for Consumer Products: Dishwashers, Clotheswashers and Clothesdryers. DOE/CE-0239, U.S. Department of Energy, Washington, D.C.

Winde11, P. A. 1987. 1987 Occupant Survey, Bonneville Power Administration, Portland, Oregon. 
Appendix A

OFFSET DRIFT ADJUSTMENTS 
Appendix A

OFFSET DRIFT ADJUSTMENTS

When the ELCAP data logger converts signals from sensors to digital data, a constant positive voltage is applied to each data channel to ensure that a positive voltage exits at the input to the analog-digital (A-D) converter at all times, even when the sensor signal is zero watts. The standard offset in the ELCAP data logger is equal to 10 counts on the 256count (8-bit) A-D converter. However, it has been observed in both the laboratory and the field that these offsets, set for each channel at the time of installation, can drift from their standard values because of effects such as ambient temperature and humidity at the logger and age of the equipment. Typical changes in offset values, referred to as offset drift, can affect the digital count representing a metered load by \pm 1 count, or more rarely \pm 2 counts.

These offset drifts typically cause errors in the metered loads of a small fraction of the average load. For example, a metered load that averages only $20 \%$ of full scale is about $2 \%$.

$$
\begin{aligned}
& \text { Ful1 scale }=256-10=246 \text { counts } \\
& \text { Error }= \pm 1 /(246 \star 0.20)=0.02=2 \%
\end{aligned}
$$

Considerable effort was directed toward determining actual offsets some months after logger installation and toward scaling the data channel ranges to the size of the circuit breakers involved, to keep errors as small as possible.

However, for appliances that are used infrequently and intermittently, these errors can accumulate. Similarly, for analyses that rely on searching for zero loads, such as the detection of vacancy as described in Appendix B, any positive offset drift will result in slightly positive loads (1 count on the logger, converted to watt-hours by data processing). 
To avoid errors introduced by uncorrected offset drifts, a simple method of detecting and correcting positive offsets was developed and is described here. This method is applicable to any metered loads from appliances, such as water heaters, that can be assumed to have zero load at least 1 hour each day. It is described here because it may prove to be of general use in analysis of ELCAP mettred data.

Step 1. The offset is estimated as the daily minimum load.

Step 2. Each daily offset is then repeated 24 times to expand it to hourly farm.

Step 3. A simple range test is applied to ensure that the offset estimate is not really an appliance with a continuous load. Offsets greater than +4 counts (in the case of the water heater analysis 75 watts) are set to zero.

Step 4. The offset is subtracted from the metered data to produce the offset adjusted data.

Casual observation indicated most water heating data had no offsets. However, a number of sites had offsets that changed at some point in time by 1 or 2 counts, while others had offset drift that appeared intermittently. 
Appendix B

VACANCY DETECTION 
Periods when occupants are not home (vacancies) have proven useful for a number of ELCAP analyses (including the hot water load analys is described in this report.) Therefore, a flag indicating vacancy periods is generated during the course of the ELCAP data processing for each site. The algorithm used is described here.

Step 1. If any of the end uses food preparation (the range/oven), clothes dryer, clothes washer, or dishwasher show a single hour or more of nonzero loads (actually loads above a small threshold accounting for possible offset drift, as described in Appendix A) during a day, this is taken as an indication that someone was definiteiy home that day. If occupancy is indicated for a given day, Step 2 is skipped.

Step 2. However, it is possible that the appliances screened in Step 1 above may not have been used. As a further test, the hot water end use is examined. Here, standby loads are typically expected even during vacant periods. "o account for this, hot water demand loads, which are generally lalge compared to the standby loads, are indicated by the ratio of the maximum value for the day to the average nonzero value for the day. If no occupancy was detected in Step 1, a flag is assigned indicating the certainty with which a vacancy is indicated by the hot water loads:

$$
\begin{array}{lll}
0 \leq \operatorname{ratio} \leq 1.6 & : & \text { flag }=\text { "vacant" } \\
1.6<\operatorname{ratio} \leq 2.0 & : & \text { flag }=\text { "possibly vacant" } \\
2.0<\operatorname{ratio} \leq 2.5: & \text { flag = "uncertain" } \\
2.5<\operatorname{ratio} & : & \text { flag }=\text { "occupied" }
\end{array}
$$

These limits were developed empirically through visual examinations of the flags as correlated with the other appliance incicators of vacancy, and were found to work well. 


\section{Correction to the Preprocessed Vacancy Flags}

Unfortunately, the flag created by the standard ELCAP data processing system does not implement Step 2 exactly as described. Instead, it computes the ratio of the average value for the day to the minimum nonzero value fur the day. This generally produces similar results, but loads that jusi barely fall into the next hour may be very small as recorded by the data logger for that subsequent hour, thus forming the minimum load for the day and making the ratio very large.

A correction to the preprocessed vacancy flag can be developed as follows:

Step 1. Compute the ratio as described in Step 2 of the vacancy flag algorithm.

Step 2. Compute the ratio incorrectly. If the preprocessed vacancy flag indicates occupancy, but not because of the incorrect ratio, then the flag was set because of consumption by one of the other appliances and therefore should be accepted as valid. If so, the flag is set to occupire for that day, and Step 3. is skipped.

Step 3. If the vacancy flag was not set to "occupied" by the other appliances (Step 2), assign the flag on the basis of the corrected ratio.

This process allows reconstruction of the correct vacancy flag, adjusted for offsets in the hot water load (see Appendix A) if desired, without requiring information as to the "on" load thresholds used for the other vacancy-indicating appliances in each of the homes. 
APPENDIX C

TANK LOCATION AIR TEMPERATURE ESTIMATION 


\section{Appendix C \\ TANK LOCATION AIR TEMPERATURE ESTIMATION}

After standby loads are estimated for each hot water tank, the heat loss coefficient (UA) can be estimated by dividing the standby load by the average air temperature at the location of the hot water tank. The heat loss coefficiunts adjust the standby loads for the fact that, all other conditions being equal, a tank in a colder location will lose more heat (have a higher standby load) than the same tank in a warmer location. Effective and nominal $R$-values for the tanks are then estimated by taking the reciprocal of the heat loss coefficients divided by the surface area of the tanks, and also by estimating the effect of pipe losses and reduced losses resulting from conservation measures, respectively.

Temperatures measured by the ELCAP project include indoor and outdoor air temperatures. However, many hot water tanks are not located in conditioned spaces where temperatures are measured. Therefore, tank location air temperatures must be estimated for locations such as basements, garages, and crawlspaces. A rigorous approach to estimating tank location temperatures might involve running thermal simulations of typical homes with garages, basements, etc. In these locations, the air temperature lies somewhere between the indoor and outdoor air temperatures and may be more stable than the normal daily fluctuations of these temperatures (especially in crawlspaces and basements) because of the thermal lag introduced by the mass of the ground. However, the considerable effort required to conduct the simulations was not deemed justified since in any event home configurations and thermostat behavior vary widely. Instead, a simple means of approximating these temperatures was developed. This appendix describes how this estimation was accompli ished.

The tank location temperature was estimated as a weighted average of the indoor and outdoor air temperatures. The weighting factors were developed using simple steady-state heat loss calculations of typical home configurations and engineering judgement. Because air temperatures in locations such as crawlspaces and basements are much more stable than indoor 
or especially outdoor temperatures, daily or monthly average temperatures were used for some tank configurations.

Table $\mathrm{C}-1$ is a summary of the method used to estimate tank location temperature. Tank locations were classified into eight generic locations, and the location temperatures were computed as the weighted average of the indoor and outdoor air temperatures using the weights indicated in the table. The time aggregation (the time interval over which the metered temperatures are averaged) used in the calculation are also indicated.

Air temperatures surrounding tanks located in above-grade conditioned spaces are simply assumed to be equal to the primary hourly air temperature measured for the home. Similarly, the few tanks in outdoor locations used measured outdoor air temperatures from the nearest weather station. Heated basements in ELCAP homes have been found to have average air temperatures about $10^{\circ} \mathrm{F}$ lower than the primary living space. A weighted average of indoor

Table $\mathrm{C}-1$

Summary of Method Used to Estimate Tank Location Air Temperature

\section{Tank Location}

Occupied Zone Heated Basement Daylight Basement Unheated Basement Porch/Sunspace Crawlspace Garage Outdoors

\section{Indoor Air Temp. Weight Aggregation}

1.0 Hourly

0.6 Daily

0.6 Daily

J.4 Daily

0.5

0.4

0.2

0.0 Hourly Daily Hourly

\section{Outdoor Air Temp. Weight Aggregation}

* Rolling 30-day average.

**Average of rolling 30-day average and hourly. 
and outdoor air temperatures $(0.6$ and 0.4$)$, respectively, are used for heated (including daylight) basements. Temperatures in basements do not fluctuate very quickly in response to thermostat setbacks because of their massive construction, daily average indoor air temperatures were used.

Because of the ground surrounding the walls in basements takes a very long time to heat up in spring and cool down in the fall and does not respond quickly enough to reflect hourly or even daily changes in outdoor temperatures. The outdoor temperature used for heated basements was the 30day rolling average outdoor air temperature for the period ending 1 month earlier. That is, for a given day, the outdoor air temperature "felt" by heated basements was assumed to be the average for the prior 30th through 59th days. For example, the average temperature for a heated basement on December 30 is the average for the prior November.

Unheated basements are treated similarly, except to reflect the fact that they are cooler, their temperature was assumed to be weighted 0.4 and 0.6 between indoor and outdoors, respectively.

Heated basements are defined as having four underground walls, while daylight basements have one or more walls above grade and larger windows. Therefore, daylight basements do respond to changes in hourly outdoor air temperatures. So for daylight basements, the outdoor air temperature was assumed to be the average of irle hourly and lagged rolling average monthly temperatures.

Crawlspaces were treated similar to daylight basements, because a significant portion of their heat is lost directly to the outdoors instead of through the ground. Like unheated basements, they are more strongly coupled to the outdoors, so their temperature is weighted between indoor and outdoor air temperatures using weights of 0.4 and 0.6 , respectively.

Porches and sunspaces were determined to be approximately equally coupled to the indoor and outdoor air temperatures, so a simple average was used. 
This method to estimate tank location air temperature was used for both long-term averages and for hourly values used to convert standby loads from a given time of day and year into an equivalent heat loss at the long-term average tank location temperature for each home. Thus, biases in the time of day and time of year whe? standby load events and vacancies are detected are reduced or el iminated. 
Appendix D

THERMAL SIMULATION OF STANDBY EVENTS IN HOT MATER TANKS 


\section{AppendiX D \\ THERMAL SIMULATION OF STANDBY EVENTS IN HOT WATER TANKS}

The basic equation governing standby heat loss, Equation (3-2), has already been discussed. It is used, along with the equation for the rate of change of heat represented by the change in tank temperature

$$
Q_{\text {tank }}=\rho C_{p} V_{\text {tank }}\left(T_{1}-T_{2}\right) / \Delta t_{12}
$$

where, $T_{1}$ and $T_{2}$ are the temperature of the water $\left({ }^{\circ} \mathrm{F}\right)$ at the beginning and end of time interval $\Delta t_{12}$, and $v_{\text {tank }}$ is the volume of the tank. As before, $p$ and $C_{p}$ are constants: the density and specific heat capacity of water.

The rate at which the tank cools is governed by a simple heat balance -the heat lost by the tank must be equal to the heat represented by the drop in temperature of the water in the tank. Setting the heat loss of Equation (3-2) equal to $Q_{\text {tank }}$ gives

$$
\text { UA }\left(T_{1}-T_{\text {local }}\right)=\rho C_{p} V_{\text {tank }}\left(T_{1}-T_{2}\right) / \Delta t_{12}
$$

As before, $T_{\text {local }}$ is the temperature of the air surrounding the tank, and $U A$ is the heat loss coefficient of the tank. To simplify calculations, the temperature at the beginning of the period is used instead of the average temperature during the period (the average of $T_{1}$ and $T_{2}$ ). This introduces only a negligible error in the simulation under normal circumstances.

If $T_{1}$ is known from the previous time step, Equation (D-2) can be solved to give a prediction of $T_{2}$ if no warmup heat is added

$$
T_{2}=T_{1}-\frac{U A\left(T_{1}-T_{\text {local }}\right)}{\rho C_{p} V_{\text {tank }} / \Delta t_{12}}
$$

The simulation of the thermostat says simply that if $T_{2}$ is less than the hot water setpoint, then the heating element will be energized until the water temperature reaches the top of the thermostat deadband. The energy of the 
warmup event can be calculated using Equation ( $D-1)$, with the temperatures $T_{1}$ and $T_{2}$ equal to the hot water setpoint and the top of the thermostat deadband, respectively. The temperature decay process then begins again.

For hot water tanks with two heating elements, th: top element is assumed to heat only the water above it. The bottom e rement heats only the water below the top element, unless the water in the upper portion of the tank is cooler than the bottom element thermostat setpoinc plus its deadband. In this case, the lower element heats all the water in the tank to this temperature.

The model assumes no stratification of water in the tank from natural convection currents induced by the heat loss process, which effectively causes dissimilar heat loss rates due to uneven temperatures. It also causes event energies and intervals to be different. Therefore, the chaotic standby event pattern illustrated in Figure 5.5 does not depend on either the assumption of uneven thermostat deadbands or on unequal portions of the tank being heated by each element. 


\section{Appendix E}

\section{EFFECTS OF VACANCY SETBACKS AND DUELING THERMOSTATS}

ON STANDBY LOAD ESTIMATES 
TABLE E-1

Effects of Vacancy Setbacks and Dueling Thermostats for

Calibration and Noncalibration Standby Loads

(avg. watts, except ratios)

\begin{tabular}{|c|c|c|c|c|c|}
\hline Sample & $\frac{\text { Ratio of } M E}{\text { Untrimmed }}$ & $\frac{\text { an Energy to }}{\text { Trimmed } 10 \%}$ & $\frac{\text { Mean Interval }}{\text { Trimmed } 25 \%}$ & $\begin{array}{l}\text { Mean } \\
\text { Event } \\
\text { Ratio }\end{array}$ & $\begin{array}{l}\text { No. of } \\
\text { Homes }\end{array}$ \\
\hline \multicolumn{6}{|l|}{ All Calibration } \\
\hline $\begin{array}{l}\text { Vacant } \\
\text { Occupied (all est.) } \\
\text { Occupied (and vacant) } \\
\text { Calibration Ratio }\end{array}$ & $\begin{array}{r}123 \\
166 \\
166 \\
1.39\end{array}$ & $\begin{array}{l}123 \\
156 \\
156 \\
1.30\end{array}$ & $\begin{array}{l}124 \\
155 \\
155 \\
1.29\end{array}$ & $\begin{array}{r}136 \\
193 \\
193 \\
1.47\end{array}$ & $\begin{array}{l}104 \\
104 \\
104 \\
104\end{array}$ \\
\hline \multicolumn{6}{|l|}{ Calibration (dueling) } \\
\hline $\begin{array}{l}\text { Vacant } \\
\text { Occupied (all est.) } \\
\text { Occupied (and vacant) } \\
\text { Calibration Ratio }\end{array}$ & $\begin{array}{l}122 \\
171 \\
171 \\
1.43\end{array}$ & $\begin{array}{r}122 \\
157 \\
157 \\
1.31\end{array}$ & $\begin{array}{r}122 \\
153 \\
153 \\
1.28\end{array}$ & $\begin{array}{r}146 \\
212 \\
212 \\
1.49\end{array}$ & $\begin{array}{l}32 \\
32 \\
32 \\
32\end{array}$ \\
\hline \multicolumn{6}{|l|}{ Calibration (not dueling) } \\
\hline $\begin{array}{l}\text { Vacant } \\
\text { Occupied (all est.) } \\
\text { Occupied (and vacant) } \\
\text { Calibration Ratio }\end{array}$ & $\begin{array}{r}123 \\
163 \\
163 \\
1.37\end{array}$ & $\begin{array}{r}124 \\
155 \\
155 \\
1.29\end{array}$ & $\begin{array}{r}124 \\
156 \\
156 \\
1.29\end{array}$ & $\begin{array}{r}131 \\
184 \\
184 \\
1.46\end{array}$ & $\begin{array}{l}72 \\
72 \\
72 \\
72\end{array}$ \\
\hline \multicolumn{6}{|l|}{ All Noncalibration } \\
\hline $\begin{array}{l}\text { Vacant } \\
\text { Occupied (all est.) } \\
\text { Occupied (and vacant) } \\
\text { Calibration Ratio }\end{array}$ & $\begin{array}{r}92 \\
190 \\
190 \\
2.17\end{array}$ & $\begin{array}{r}92 \\
177 \\
177 \\
2.03\end{array}$ & $\begin{array}{r}93 \\
172 \\
172 \\
1.95\end{array}$ & $\begin{array}{r}113 \\
242 \\
242 \\
2.28\end{array}$ & $\begin{array}{l}46 \\
46 \\
46 \\
46\end{array}$ \\
\hline \multicolumn{6}{|l|}{ Noncal ibration (dueling) } \\
\hline $\begin{array}{l}\text { Vacant } \\
\text { Occupied (all est.) } \\
\text { Occupied (and vacant) } \\
\text { Calibration Ratio }\end{array}$ & $\begin{array}{r}90 \\
193 \\
193 \\
2.27\end{array}$ & $\begin{array}{r}89 \\
182 \\
182 \\
2.15\end{array}$ & $\begin{array}{r}90 \\
178 \\
178 \\
2.08\end{array}$ & $\begin{array}{r}115 \\
253 \\
253 \\
2.38\end{array}$ & $\begin{array}{l}35 \\
35 \\
35 \\
35\end{array}$ \\
\hline \multicolumn{6}{|l|}{ Noncal ib (setback only) } \\
\hline $\begin{array}{l}\text { Vacant } \\
\text { Occupied (all est.) } \\
\text { Occupied (and vacant) } \\
\text { Calibration Ratio }\end{array}$ & $\begin{array}{r}99 \\
182 \\
182 \\
1.85\end{array}$ & $\begin{array}{r}101 \\
163 \\
163 \\
1.62\end{array}$ & $\begin{array}{l}103 \\
155 \\
155 \\
1.53\end{array}$ & $\begin{array}{l}106 \\
207 \\
207 \\
1.97\end{array}$ & $\begin{array}{l}11 \\
11 \\
11 \\
11\end{array}$ \\
\hline
\end{tabular}




\section{APPENDIX $F$}

\section{ADDITIONAL STANDBY RESULTS}


TABLE F-1

Unadjusted Standby Estimates for All Homes Analyzed

\begin{tabular}{|c|c|c|c|c|c|c|}
\hline \multirow[b]{2}{*}{ Sample } & \multicolumn{3}{|c|}{ Vacant } & \multicolumn{3}{|c|}{ Occupied } \\
\hline & Mean & $n$ & S.Dev. & Mean & $n$ & S.Dev. \\
\hline A11 ELCAP & 1084 & 305 & 515 & 1542 & 399 & 586 \\
\hline $\begin{array}{l}\text { Base-Al1 } \\
\text { - Occupied Zone } \\
\text { - Heated Basement } \\
\text {-Dayl it Basement } \\
\text { - Unheated Basement } \\
\text { - Porch/Sunspace } \\
\text { - Crawlspace } \\
\text { - Garage } \\
\text {-Outdoors }\end{array}$ & $\begin{array}{l}1128 \\
1049 \\
1205 \\
1324 \\
1124 \\
1300 \\
1160 \\
1119 \\
-\end{array}$ & $\begin{array}{r}187 \\
70 \\
39 \\
8 \\
23 \\
3 \\
11 \\
27 \\
0\end{array}$ & $\begin{array}{l}573 \\
487 \\
860 \\
468 \\
303 \\
211 \\
526 \\
519 \\
-\end{array}$ & $\begin{array}{l}1587 \\
1521 \\
1613 \\
1667 \\
1603 \\
1648 \\
1701 \\
1598 \\
1132\end{array}$ & $\begin{array}{r}252 \\
79 \\
53 \\
11 \\
34 \\
3 \\
14 \\
39 \\
1\end{array}$ & $\begin{array}{r}635 \\
530 \\
590 \\
594 \\
776 \\
587 \\
789 \\
762 \\
0\end{array}$ \\
\hline $\begin{array}{l}\text { RSDP-A11 } \\
\text {-Occupied Zone } \\
\text { - Heated Basement } \\
\text { - Dayl it Basement } \\
\text { - Unheated Basement } \\
\text { - Porch/Sunspace } \\
\text { - Crawl space } \\
\text { - Garage } \\
\text {-Outdoors }\end{array}$ & $\begin{array}{r}953 \\
967 \\
969 \\
927 \\
1570 \\
434 \\
772 \\
810 \\
-\end{array}$ & $\begin{array}{r}81 \\
36 \\
15 \\
4 \\
2 \\
1 \\
4 \\
13 \\
0\end{array}$ & $\begin{array}{r}352 \\
281 \\
406 \\
399 \\
40 \\
0 \\
247 \\
273 \\
-\end{array}$ & $\begin{array}{c}1428 \\
1424 \\
1528 \\
1434 \\
1601 \\
1214 \\
1275 \\
1436 \\
-\end{array}$ & $\begin{array}{r}98 \\
43 \\
19 \\
4 \\
3 \\
1 \\
6 \\
14 \\
0\end{array}$ & $\begin{array}{r}403 \\
366 \\
478 \\
279 \\
274 \\
0 \\
414 \\
351\end{array}$ \\
\hline Other-A11 & 1151 & 37 & 463 & 1536 & 49 & 612 \\
\hline
\end{tabular}


TABLE F-2

Valid Temperature-Adjusted Standby Estimates

\begin{tabular}{|c|c|c|c|c|c|c|}
\hline \multirow[b]{2}{*}{ Sample } & \multicolumn{3}{|c|}{ Vacant } & \multicolumn{3}{|c|}{ Occupied } \\
\hline & Mean & $n$ & S.Dev. & Mean & $n$ & S.Dev. \\
\hline ALL ELCAP & 997 & 150 & 306 & 1504 & 289 & 542 \\
\hline $\begin{array}{l}\text { Base-All } \\
\text { - Occupied Zone } \\
\text { - Heated Basement } \\
\text {-Dayl it Basement } \\
\text { - Unheated Basement } \\
\text { - Porch/Sunspace } \\
\text { - Crawlspace } \\
\text { - Garage } \\
\text {-Outdoors }\end{array}$ & $\begin{array}{c}1019 \\
1004 \\
1082 \\
1251 \\
995 \\
- \\
963 \\
955 \\
-\end{array}$ & $\begin{array}{r}88 \\
33 \\
16 \\
5 \\
10 \\
0 \\
8 \\
16 \\
0\end{array}$ & $\begin{array}{l}307 \\
326 \\
346 \\
268 \\
277 \\
- \\
331 \\
237 \\
-\end{array}$ & $\begin{array}{l}1551 \\
1500 \\
1518 \\
1721 \\
1620 \\
1845 \\
1750 \\
1514 \\
964\end{array}$ & $\begin{array}{r}182 \\
60 \\
43 \\
7 \\
26 \\
2 \\
13 \\
30 \\
1\end{array}$ & $\begin{array}{r}601 \\
532 \\
560 \\
737 \\
513 \\
616 \\
745 \\
765 \\
0\end{array}$ \\
\hline $\begin{array}{l}\text { RSDP-A1l } \\
\text {-Occupied Zone } \\
\text { - Heated Basement } \\
\text { - Dayl it Basement } \\
\text { - Unheated Basement } \\
\text { - Porch/Sunspace } \\
\text { - Crawlspace } \\
\text { - Garage } \\
\text {-Outdoors }\end{array}$ & $\begin{array}{c}928 \\
940 \\
972 \\
1105 \\
- \\
- \\
840 \\
843 \\
-\end{array}$ & $\begin{array}{r}44 \\
24 \\
7 \\
2 \\
0 \\
0 \\
3 \\
8 \\
0\end{array}$ & $\begin{array}{c}294 \\
257 \\
391 \\
486 \\
- \\
- \\
129 \\
346 \\
-\end{array}$ & $\begin{array}{c}1385 \\
1369 \\
1448 \\
1368 \\
1632 \\
- \\
1271 \\
1345 \\
-\end{array}$ & $\begin{array}{r}75 \\
35 \\
15 \\
4 \\
3 \\
0 \\
5 \\
13 \\
0\end{array}$ & $\begin{array}{c}367 \\
351 \\
459 \\
275 \\
386 \\
- \\
468 \\
302 \\
-\end{array}$ \\
\hline Other-All & 1057 & 18 & 314 & 1518 & 32 & 500 \\
\hline
\end{tabular}


TABLE F-3

Unfilled and Filled Extrapolated Standby Estimates

\begin{tabular}{|c|c|c|c|c|c|c|}
\hline \multirow[b]{2}{*}{ Sample } & \multicolumn{3}{|c|}{ Extrapolated } & \multicolumn{3}{|c|}{ Filled } \\
\hline & Mean & $n$ & S.Dev. & Mean & $n$ & S.Dev. \\
\hline All ELCAP & 1162 & 289 & 418 & 1168 & 321 & 4218 \\
\hline $\begin{array}{l}\text { Base-A11 } \\
\text {-0ccupied Zone } \\
\text { - Heated Basement } \\
\text { - Daylit Basement } \\
\text { - Unheated Basement } \\
\text { - Porch/Sunspace } \\
\text { - Crawlspace } \\
\text { - Garage } \\
\text { - Outdoors }\end{array}$ & $\begin{array}{l}1191 \\
1168 \\
1158 \\
1439 \\
1206 \\
1408 \\
1340 \\
1151 \\
736\end{array}$ & $\begin{array}{r}182 \\
60 \\
43 \\
7 \\
26 \\
2 \\
13 \\
30 \\
1\end{array}$ & $\begin{array}{r}457 \\
411 \\
454 \\
502 \\
369 \\
470 \\
569 \\
559 \\
0\end{array}$ & $\begin{array}{l}1187 \\
1159 \\
1150 \\
1439 \\
1178 \\
1251 \\
1340 \\
1180 \\
736\end{array}$ & $\begin{array}{r}203 \\
67 \\
44 \\
7 \\
30 \\
3 \\
13 \\
35 \\
1\end{array}$ & $\begin{array}{r}453 \\
394 \\
452 \\
502 \\
357 \\
430 \\
569 \\
560 \\
0\end{array}$ \\
\hline $\begin{array}{l}\text { RSDP-A11 } \\
\text { - Occupied Zone } \\
\text { - Heated Basement } \\
\text { - Dayl it Basement } \\
\text { - Unheated Basement } \\
\text { - Porch/Sunspace } \\
\text { - Crawlspace } \\
\text { - Garage } \\
\text {-Outdoors }\end{array}$ & $\begin{array}{c}1075 \\
1068 \\
1128 \\
1099 \\
1246 \\
- \\
989 \\
1016 \\
-\end{array}$ & $\begin{array}{r}75 \\
35 \\
15 \\
4 \\
3 \\
0 \\
5 \\
13 \\
0\end{array}$ & $\begin{array}{l}301 \\
266 \\
402 \\
288 \\
295 \\
- \\
350 \\
274 \\
-\end{array}$ & $\begin{array}{c}1093 \\
1092 \\
1128 \\
1099 \\
1246 \\
- \\
989 \\
1062 \\
-\end{array}$ & $\begin{array}{r}81 \\
40 \\
15 \\
4 \\
3 \\
0 \\
5 \\
14 \\
0\end{array}$ & $\begin{array}{c}308 \\
277 \\
402 \\
288 \\
295 \\
- \\
350 \\
314 \\
-\end{array}$ \\
\hline Other-A11 & 1202 & 32 & 401 & 1233 & 37 & 442 \\
\hline
\end{tabular}


TABLE F-4

Calibration and Filled Extrapolated Tank UA Estimates

\begin{tabular}{|c|c|c|c|c|c|c|}
\hline \multirow[b]{2}{*}{ Sample } & \multicolumn{3}{|c|}{ Calibration Homes } & \multicolumn{3}{|c|}{ Filled } \\
\hline & Mean & $n$ & S.Dev. & Mean & $\mathbf{n}$ & S.Dev. \\
\hline A11 ELCAP & 5.52 & 104 & 2.14 & 6.20 & 321 & 2.47 \\
\hline $\begin{array}{l}\text { Base-Al1 } \\
\text {-Occupied Zone } \\
\text { - Heated Basement } \\
\text { - Dayl it Basement } \\
\text { - Unheated Basement } \\
\text { - Porch/Sunspace } \\
\text {-Crawlspace } \\
\text { - Garage } \\
\text {-Outdoors }\end{array}$ & $\begin{array}{l}5.16 \\
5.98 \\
5.01 \\
5.94 \\
4.71 \\
- \\
2.48 \\
5.06 \\
-\end{array}$ & $\begin{array}{r}63 \\
22 \\
13 \\
4 \\
10 \\
0 \\
5 \\
9 \\
0\end{array}$ & $\begin{array}{l}2.41 \\
1.64 \\
1.59 \\
1.58 \\
1.29 \\
6.67 \\
1.39 \\
-\end{array}$ & $\begin{array}{l}6.05 \\
6.77 \\
5.79 \\
6.99 \\
5.37 \\
6.26 \\
5.48 \\
5.61 \\
4.00\end{array}$ & $\begin{array}{r}203 \\
67 \\
44 \\
7 \\
30 \\
3 \\
13 \\
35 \\
1\end{array}$ & $\begin{array}{l}2.64 \\
2.51 \\
2.41 \\
2.21 \\
1.50 \\
2.24 \\
5.00 \\
2.66 \\
0.0\end{array}$ \\
\hline $\begin{array}{l}\text { RSDP-A11 } \\
\text {-Occupied Zone } \\
\text {-Heated Basement } \\
\text {-Daylit Basement } \\
\text { - Unheated Basement } \\
\text { - Porch/Sunspace } \\
\text {-Crawlspace } \\
\text { - Garage } \\
\text { - Oatdoors }\end{array}$ & $\begin{array}{r}6.06 \\
6.43 \\
6.44 \\
7.37 \\
- \\
- \\
4.57 \\
5.13 \\
-\end{array}$ & $\begin{array}{r}30 \\
16 \\
5 \\
1 \\
0 \\
0 \\
3 \\
5 \\
0\end{array}$ & $\begin{array}{l}1.61 \\
1.44 \\
2.29 \\
0.0 \\
- \\
-. \\
0.47 \\
1.28 \\
-\end{array}$ & $\begin{array}{c}6.46 \\
6.90 \\
6.68 \\
6.61 \\
5.92 \\
5.22 \\
5.48 \\
-\end{array}$ & $\begin{array}{r}81 \\
40 \\
15 \\
4 \\
3 \\
0 \\
5 \\
14 \\
0\end{array}$ & $\begin{array}{c}1.88 \\
1.89 \\
2.17 \\
0.82 \\
1.02 \\
- \\
1.54 \\
1.63 \\
-\end{array}$ \\
\hline Other-A11 & 6.11 & 11 & 1.35 & 6.44 & 37 & 2.62 \\
\hline
\end{tabular}


APPENDIX $G$

MANUFACTURERS' DATA ON HOT WATER TANKS 
Table G-1

Nameplate Data

\begin{tabular}{|c|c|c|c|c|c|c|c|c|}
\hline $\begin{array}{l}\text { Size } \\
\text { (gal) }\end{array}$ & $\begin{array}{l}E F \\
(-)\end{array}$ & $\begin{array}{l}\text { Ht. } \\
\text { (in.) }\end{array}$ & $\begin{array}{l}\text { Dia. } \\
\text { (in.) }\end{array}$ & $\begin{array}{l}\text { Area } \\
\left(\mathrm{ft}^{2}\right)\end{array}$ & $\begin{array}{l}\text { Insul. } \\
\text { Thick. } \\
\text { (in.) }\end{array}$ & $\begin{array}{l}\text { Nominal } \\
\text { R-Value } \\
\left({ }^{\circ} \mathrm{F}-\mathrm{ft}^{2}-\right. \\
\mathrm{hr} / \text { Btu })\end{array}$ & $\begin{array}{l}\text { Pipe } \\
\text { Heat } \\
\text { Trap } \\
(-)\end{array}$ & Model \\
\hline $\begin{array}{l}30 \\
40 \\
52 \\
82\end{array}$ & $\begin{array}{l}0.98 \\
0.97 \\
0.95 \\
0.91\end{array}$ & $\begin{array}{l}47.875 \\
59.750 \\
59.438 \\
60.250\end{array}$ & $\begin{array}{l}19.000 \\
19.000 \\
21.000 \\
25.000\end{array}$ & $\begin{array}{l}23.78 \\
28.71 \\
32.04 \\
39.68\end{array}$ & $\begin{array}{l}2.5 \\
2.5 \\
2.5 \\
2.5\end{array}$ & $\begin{array}{l}20.83 \\
20.83 \\
20.83 \\
20.83\end{array}$ & $\begin{array}{l}1 \\
1 \\
1 \\
1\end{array}$ & $\begin{array}{l}\text { Power Miser } 10^{(a)} \\
\text { Power Miser } 10 \\
\text { Power Miser } 10 \\
\text { Power Miser } 10\end{array}$ \\
\hline $\begin{array}{l}30 \\
40 s^{(b)} \\
40 \\
52 \\
66 \\
82\end{array}$ & $\begin{array}{l}0.94 \\
0.91 \\
0.93 \\
0.91 \\
0.89 \\
0.87\end{array}$ & $\begin{array}{l}47.875 \\
32.125 \\
59.750 \\
59.438 \\
60.125 \\
60.250\end{array}$ & $\begin{array}{l}19.000 \\
25.000 \\
19.000 \\
21.000 \\
23.000 \\
25.000\end{array}$ & $\begin{array}{l}23.78 \\
24.34 \\
28.71 \\
32.04 \\
35.94 \\
39.68\end{array}$ & $\begin{array}{l}2.5 \\
2.5 \\
2.5 \\
2.5 \\
2.5 \\
2.5\end{array}$ & $\begin{array}{l}20.83 \\
20.83 \\
20.83 \\
20.83 \\
20.83 \\
20.83\end{array}$ & $\begin{array}{l}0 \\
0 \\
0 \\
0 \\
0 \\
0\end{array}$ & $\begin{array}{l}\text { Power Miser } 8^{(a)} \\
\text { Power Miser } 8 \\
\text { Power Miser } 8 \\
\text { Power Miser } 8 \\
\text { Power Miser } 8 \\
\text { Power Miser } 8\end{array}$ \\
\hline $\begin{array}{l}30 s \\
30 \\
40 s \\
40 \\
52\end{array}$ & $\begin{array}{l}0.91 \\
0.93 \\
0.90 \\
0.92 \\
0.90\end{array}$ & $\begin{array}{l}30.000 \\
45.750 \\
32.125 \\
59.750 \\
59.438\end{array}$ & $\begin{array}{l}22.000 \\
18.000 \\
24.000 \\
18.000 \\
20.000\end{array}$ & $\begin{array}{l}19.68 \\
21.50 \\
23.10 \\
27.00 \\
30.30\end{array}$ & $\begin{array}{l}2.0 \\
2.0 \\
2.0 \\
2.0 \\
2.0\end{array}$ & $\begin{array}{l}16.66 \\
16.66 \\
16.66 \\
16.66 \\
16.66\end{array}$ & $\begin{array}{l}0 \\
0 \\
0 \\
0 \\
0\end{array}$ & $\begin{array}{l}\text { Economizer }^{(a)} \\
\text { Economizer } \\
\text { Economizer } \\
\text { Economizer } \\
\text { Economizer }\end{array}$ \\
\hline $\begin{array}{l}30 \\
40 \\
50 \\
65 \\
80\end{array}$ & $\begin{array}{l}0.97 \\
0.96 \\
0.96 \\
0.95 \\
0.94\end{array}$ & $\begin{array}{l}45.625 \\
46.125 \\
56.688 \\
59.250 \\
59.375\end{array}$ & $\begin{array}{l}20.438 \\
22.438 \\
22.438 \\
24.438 \\
26.250\end{array}$ & $\begin{array}{l}24.90 \\
28.07 \\
33.24 \\
38.10 \\
41.52\end{array}$ & $\begin{array}{l}3.0 \\
3.0 \\
3.0 \\
3.0 \\
3.0\end{array}$ & $\begin{array}{l}24.99 \\
24.99 \\
24.99 \\
24.99 \\
24.99\end{array}$ & $\begin{array}{l}1 \\
1 \\
1 \\
1 \\
1\end{array}$ & $\begin{array}{l}\text { Tri Power Imp. }{ }^{(c)} \\
\text { Tri Power Imp. } \\
\text { Tri Power Imp. } \\
\text { Tri Power Imp. } \\
\text { Tri Power Imp. }\end{array}$ \\
\hline $\begin{array}{l}30 \\
40 \\
50 \\
65 \\
80\end{array}$ & $\begin{array}{l}0.92 \\
0.91 \\
0.90 \\
0.89 \\
0.88\end{array}$ & $\begin{array}{l}45.125 \\
46.125 \\
56.500 \\
58.500 \\
58.625\end{array}$ & $\begin{array}{l}18.438 \\
20.438 \\
20.438 \\
22.438 \\
24.438\end{array}$ & $\begin{array}{l}21.86 \\
25.12 \\
29.75 \\
34.13 \\
37.77\end{array}$ & $\begin{array}{l}2.0 \\
2.0 \\
2.0 \\
2.0 \\
2.0\end{array}$ & $\begin{array}{l}16.66 \\
16.66 \\
16.66 \\
16.66 \\
16.66\end{array}$ & $\begin{array}{l}0 \\
0 \\
0 \\
0 \\
0\end{array}$ & $\begin{array}{l}\text { Eight Plus (c) } \\
\text { Eight Plus } \\
\text { Eight Plus } \\
\text { Eight Plus } \\
\text { Eight Plus }\end{array}$ \\
\hline $\begin{array}{l}30 \\
40 \\
50 \\
65\end{array}$ & $\begin{array}{l}0.91 \\
0.91 \\
0.88 \\
0.88\end{array}$ & $\begin{array}{l}45.688 \\
46.500 \\
57.063 \\
58.813\end{array}$ & $\begin{array}{l}17.000 \\
19.000 \\
19.000 \\
21.000\end{array}$ & $\begin{array}{l}20.10 \\
23.21 \\
27.59 \\
31.76\end{array}$ & $\begin{array}{l}1.8 \\
1.8 \\
1.8 \\
1.8\end{array}$ & $\begin{array}{l}14.58 \\
14.58 \\
14.58 \\
14.58\end{array}$ & $\begin{array}{l}0 \\
0 \\
0 \\
0\end{array}$ & $\begin{array}{l}\text { Imperial/Stnd. } \\
\text { Imperial/Stnd. } \\
\text { Imperial/Stnd. } \\
\text { Imperial/Stnd. }\end{array}$ \\
\hline
\end{tabular}


Table G-1 (continued)

\begin{tabular}{|c|c|c|c|c|c|c|c|c|}
\hline $\begin{array}{l}\text { Size } \\
\text { (gal) }\end{array}$ & $\begin{array}{l}E F \\
(-)\end{array}$ & $\begin{array}{l}\text { Ht. } \\
\text { (in.) }\end{array}$ & $\begin{array}{l}\text { Dia. } \\
\text { (in.) }\end{array}$ & $\begin{array}{l}\text { Area } \\
\left(\mathrm{ft}^{2}\right)\end{array}$ & $\begin{array}{l}\text { Insul. } \\
\text { Thick. } \\
\text { (in.) }\end{array}$ & $\begin{array}{l}\text { Nominal } \\
\mathrm{R}-\text { Value } \\
\left(\circ \mathrm{F}-\mathrm{ft}^{2}-\right. \\
\mathrm{hr} / \mathrm{Btu})\end{array}$ & $\begin{array}{l}\text { Pipe } \\
\text { Heat } \\
\text { Trap } \\
(-)\end{array}$ & Model \\
\hline $\begin{array}{l}80 \\
120 \\
50 \mathrm{~m}^{(d)} \\
20 \mathrm{~s} \\
30 \mathrm{~s} \\
40 \mathrm{~s} \\
47 \mathrm{~s} \\
50 \mathrm{~s}\end{array}$ & $\begin{array}{l}0.87 \\
0.82 \\
0.90 \\
0.94 \\
0.91 \\
0.91 \\
0.91 \\
0.89\end{array}$ & $\begin{array}{l}59.000 \\
61.875 \\
46.063 \\
31.750 \\
29.750 \\
32.563 \\
31.875 \\
39.000\end{array}$ & $\begin{array}{l}23.000 \\
26.250 \\
21.000 \\
17.750 \\
21.750 \\
23.750 \\
26.250 \\
23.000\end{array}$ & $\begin{array}{l}35.38 \\
42.95 \\
25.91 \\
15.73 \\
19.28 \\
23.03 \\
25.77 \\
25.34\end{array}$ & $\begin{array}{l}1.8 \\
1.8 \\
1.8 \\
1.8 \\
1.8 \\
1.8 \\
1.8 \\
1.8\end{array}$ & $\begin{array}{l}14.58 \\
14.58 \\
14.58 \\
14.58 \\
14.58 \\
14.58 \\
14.58 \\
14.58\end{array}$ & $\begin{array}{l}0 \\
0 \\
0 \\
0 \\
0 \\
0 \\
0 \\
0\end{array}$ & $\begin{array}{l}\text { Imperial/Stnd. } \\
\text { Imperial/Stnd. } \\
\text { Imperial/Stnd. } \\
\text { Imperial/Stnd. } \\
\text { Imperial/Stnd. } \\
\text { Imperial/Stnd. } \\
\text { Imperial/Stnd. } \\
\text { Imperial/Stnd. }\end{array}$ \\
\hline
\end{tabular}
(a) Sears and Robuck.
(b) $s$ indicates short model.
(c) Rheen.
(d) $m$ indicates medium height model. 
Table G-2

Estimated Net Dimensions

\begin{tabular}{|c|c|c|c|c|c|c|c|c|c|}
\hline $\begin{array}{l}\text { Size } \\
\text { (gal) }\end{array}$ & $\begin{array}{l}E F \\
(-)\end{array}$ & $\begin{array}{l}\text { Act. } \\
\text { Size } \\
\text { (gal) }\end{array}$ & $\begin{array}{l}\text { Dia.j } \\
\text { (in.) }\end{array}$ & $\begin{array}{l}\text { Ht. } \\
\text { (in.) }\end{array}$ & $\begin{array}{l}\text { Total } \\
\text { Area } \\
\left(\mathrm{ft}^{2}\right)\end{array}$ & $\begin{array}{l}\text { Side } \\
\text { Area } \\
\left(\mathrm{ft}^{2}\right)\end{array}$ & $\begin{array}{l}\text { End } \\
\text { Area } \\
\left(\mathrm{ft}^{2}\right)\end{array}$ & $\begin{array}{l}\text { Surface } \\
\text { Volume } \\
\text { Ratio, ID } \\
\left(\mathrm{ft}^{2} / \mathrm{gal}\right)\end{array}$ & $\begin{array}{l}\text { RValue, } \\
\text { Wall, ID } \\
\left({ }^{\circ} \mathrm{F}-\mathrm{ft}^{2}-\right. \\
\mathrm{hr} / \mathrm{Btu})\end{array}$ \\
\hline $\begin{array}{l}30 \\
40 \\
52 \\
82\end{array}$ & $\begin{array}{l}0.98 \\
0.97 \\
0.95 \\
0.91\end{array}$ & $\begin{array}{l}27.0 \\
36.0 \\
46.8 \\
73.8\end{array}$ & $\begin{array}{l}14.0 \\
14.0 \\
16.0 \\
20.0\end{array}$ & $\begin{array}{l}40.5 \\
54.0 \\
53.8 \\
54.3\end{array}$ & $\begin{array}{l}14.5 \\
18.6 \\
21.6 \\
28.0\end{array}$ & $\begin{array}{l}12.38 \\
16.50 \\
18.77 \\
23.68\end{array}$ & $\begin{array}{l}2.14 \\
2.14 \\
2.79 \\
4.36\end{array}$ & $\begin{array}{l}0.54 \\
0.52 \\
0.46 \\
0.38\end{array}$ & $\begin{array}{l}17.81 \\
17.81 \\
18.12 \\
18.59\end{array}$ \\
\hline $\begin{array}{l}30 \\
40 s^{(a)} \\
40 \\
52 \\
66 \\
82\end{array}$ & $\begin{array}{l}0.94 \\
0.91 \\
0.93 \\
0.91 \\
0.89 \\
0.87\end{array}$ & $\begin{array}{l}27.0 \\
36.0 \\
36.0 \\
46.8 \\
59.4 \\
73.8\end{array}$ & $\begin{array}{l}14.0 \\
20.0 \\
14.0 \\
16.0 \\
18.0 \\
20.0\end{array}$ & $\begin{array}{l}40.5 \\
26.5 \\
54.0 \\
53.8 \\
53.9 \\
54.3\end{array}$ & $\begin{array}{l}14.5 \\
15.9 \\
18.6 \\
21.6 \\
24.7 \\
28.0\end{array}$ & $\begin{array}{l}12.38 \\
11.55 \\
16.50 \\
18.77 \\
21.18 \\
23.68\end{array}$ & $\begin{array}{l}2.14 \\
4.36 \\
2.14 \\
2.79 \\
3.53 \\
4.36\end{array}$ & $\begin{array}{l}0.54 \\
0.44 \\
0.52 \\
0.46 \\
0.42 \\
0.38\end{array}$ & $\begin{array}{l}17.81 \\
18.59 \\
17.81 \\
18.12 \\
18.38 \\
18.59\end{array}$ \\
\hline $\begin{array}{l}30 s \\
30 \\
40 s \\
40 \\
52\end{array}$ & $\begin{array}{l}0.91 \\
0.93 \\
0.90 \\
0.92 \\
0.90\end{array}$ & $\begin{array}{l}27.0 \\
27.0 \\
36.0 \\
36.0 \\
46.8\end{array}$ & $\begin{array}{l}18.0 \\
14.0 \\
20.0 \\
14.0 \\
16.0\end{array}$ & $\begin{array}{l}24.5 \\
40.5 \\
26.5 \\
54.0 \\
53.8\end{array}$ & $\begin{array}{l}13.2 \\
14.5 \\
15.9 \\
18.6 \\
21.6\end{array}$ & $\begin{array}{r}9.63 \\
12.38 \\
11.55 \\
16.50 \\
18.77\end{array}$ & $\begin{array}{l}3.53 \\
2.14 \\
4.36 \\
2.14 \\
2.79\end{array}$ & $\begin{array}{l}0.49 \\
0.54 \\
0.44 \\
0.52 \\
0.46\end{array}$ & $\begin{array}{l}15.04 \\
14.65 \\
15.19 \\
14.65 \\
14.87\end{array}$ \\
\hline $\begin{array}{l}30 \\
40 \\
50 \\
65 \\
80\end{array}$ & $\begin{array}{l}0.97 \\
0.96 \\
0.96 \\
0.95 \\
0.94\end{array}$ & $\begin{array}{l}27.0 \\
36.0 \\
45.0 \\
58.5 \\
72.0\end{array}$ & $\begin{array}{l}14.4 \\
16.4 \\
16.4 \\
18.4 \\
20.3\end{array}$ & $\begin{array}{l}38.1 \\
39.2 \\
49.0 \\
50.6 \\
51.6\end{array}$ & $\begin{array}{l}14.3 \\
17.0 \\
20.5 \\
24.1 \\
27.3\end{array}$ & $\begin{array}{l}12.00 \\
14.05 \\
17.57 \\
20.36 \\
22.82\end{array}$ & $\begin{array}{l}2.27 \\
2.95 \\
2.95 \\
3.71 \\
4.47\end{array}$ & $\begin{array}{l}0.53 \\
0.47 \\
0.46 \\
0.41 \\
0.38\end{array}$ & $\begin{array}{l}20.90 \\
21.30 \\
21.30 \\
21.63 \\
21.89\end{array}$ \\
\hline $\begin{array}{l}30 \\
40 \\
50 \\
65 \\
80\end{array}$ & $\begin{array}{l}0.92 \\
0.91 \\
0.90 \\
0.89 \\
0.88\end{array}$ & $\begin{array}{l}27.0 \\
36.0 \\
45.0 \\
58.5 \\
72.0\end{array}$ & $\begin{array}{l}14.4 \\
16.4 \\
16.4 \\
18.4 \\
20.4\end{array}$ & $\begin{array}{l}38.1 \\
39.2 \\
49.0 \\
50.6 \\
50.7\end{array}$ & $\begin{array}{l}14.3 \\
17.0 \\
20.5 \\
24.1 \\
27.2\end{array}$ & $\begin{array}{l}12.00 \\
14.05 \\
17.57 \\
20.36 \\
22.61\end{array}$ & $\begin{array}{l}2.27 \\
2.95 \\
2.95 \\
3.71 \\
4.56\end{array}$ & $\begin{array}{l}0.53 \\
0.47 \\
0.46 \\
0.41 \\
0.38\end{array}$ & $\begin{array}{l}14.71 \\
14.91 \\
14.91 \\
15.08 \\
15.22\end{array}$ \\
\hline $\begin{array}{l}30 \\
40 \\
50 \\
65 \\
80 \\
120 \\
50 \mathrm{~m}^{(b)} \\
20 \mathrm{~s}\end{array}$ & $\begin{array}{l}0.91 \\
0.91 \\
0.88 \\
0.88 \\
0.87 \\
0.82 \\
0.90 \\
0.94\end{array}$ & $\begin{array}{r}27.0 \\
36.0 \\
45.0 \\
58.5 \\
72.0 \\
108.0 \\
45.0 \\
18.0\end{array}$ & $\begin{array}{l}13.5 \\
15.5 \\
15.5 \\
17.5 \\
19.5 \\
22.8 \\
17.5 \\
14.3\end{array}$ & $\begin{array}{l}43.6 \\
44.1 \\
55.1 \\
56.2 \\
55.7 \\
61.4 \\
43.2 \\
26.1\end{array}$ & $\begin{array}{l}14.8 \\
17.5 \\
21.3 \\
24.8 \\
27.8 \\
36.1\end{array}$ & $\begin{array}{l}12.83 \\
14.90 \\
18.63 \\
21.45 \\
23.69 \\
30.46 \\
16.50\end{array}$ & $\begin{array}{l}1.99 \\
2.62 \\
2.62 \\
3.34 \\
4.15 \\
5.65 \\
3.34 \\
2.22\end{array}$ & $\begin{array}{l}0.55 \\
0.49 \\
0.47 \\
0.42 \\
0.39 \\
0.33 \\
0.44 \\
0.57\end{array}$ & $\begin{array}{l}12.96 \\
13.14 \\
13.14 \\
13.29 \\
13.41 \\
13.56 \\
13.29 \\
13.04\end{array}$ \\
\hline
\end{tabular}


Table G-2 (continued)

\begin{tabular}{|c|c|c|c|c|c|c|c|c|c|}
\hline $\begin{array}{l}\text { Size } \\
\text { (gal) }\end{array}$ & $\begin{array}{l}E F \\
(-)\end{array}$ & $\begin{array}{l}\text { Act. } \\
\text { Size } \\
\text { (gal) }\end{array}$ & $\begin{array}{l}\text { Dia. } \\
\text { (in.) }\end{array}$ & $\begin{array}{l}\mathrm{Ht} . \\
\text { (in.) }\end{array}$ & $\begin{array}{l}\text { Total } \\
\text { Area } \\
\left(\mathrm{ft}^{2}\right)\end{array}$ & $\begin{array}{l}\text { Side } \\
\text { Area } \\
\left(\mathrm{ft}^{2}\right)\end{array}$ & $\begin{array}{l}\text { End } \\
\text { Area } \\
\left(\mathrm{ft}^{2}\right)\end{array}$ & $\begin{array}{l}\text { Surface } \\
\text { Volume } \\
\text { Ratio, ID } \\
\text { (ft } \text { ft }^{2} \text { gal) }\end{array}$ & $\begin{array}{l}\text { R-Value, } \\
\text { Wall, ID } \\
\left({ }^{\circ} \mathrm{F}-\mathrm{ft}^{2}-\right. \\
\mathrm{hr} / \mathrm{Btu})\end{array}$ \\
\hline $\begin{array}{l}30 s \\
40 s \\
47 s \\
50 s\end{array}$ & $\begin{array}{l}0.91 \\
0.91 \\
0.91 \\
0.89\end{array}$ & $\begin{array}{l}27.0 \\
36.0 \\
42.3 \\
45.0\end{array}$ & $\begin{array}{l}18.3 \\
20.3 \\
22.8 \\
19.5\end{array}$ & $\begin{array}{l}23.8 \\
25.8 \\
24.0 \\
34.8\end{array}$ & $\begin{array}{l}13.1 \\
15.9 \\
17.6 \\
19.0\end{array}$ & $\begin{array}{r}9.49 \\
11.41 \\
11.93 \\
14.81\end{array}$ & $\begin{array}{l}3.63 \\
4.47 \\
5.65 \\
4.15\end{array}$ & $\begin{array}{l}0.49 \\
0.44 \\
0.42 \\
0.42\end{array}$ & $\begin{array}{l}13.34 \\
13.45 \\
13.56 \\
13.41\end{array}$ \\
\hline
\end{tabular}

(a) $s$ indicates short model.

(b) $m$ indicates medium height model. 
TABLE G.3

Standby Loss Calculations

\begin{tabular}{|c|c|c|c|c|c|c|c|c|c|c|c|}
\hline \multirow[b]{2}{*}{$\begin{array}{l}\text { Size } \\
\text { (gal) }\end{array}$} & \multirow[b]{2}{*}{$\begin{array}{l}E F \\
(-)\end{array}$} & \multirow{2}{*}{$\begin{array}{l}\text { Adj. } \\
E F \\
(-)\end{array}$} & \multicolumn{6}{|c|}{ Heat Loss Coef. (Btu/hr-of $)$} & \multirow{2}{*}{\multicolumn{2}{|c|}{$\begin{array}{c}\text { End } \\
\text { R-Va]ue } \\
(\circ \mathrm{F}-\mathrm{ft}- \\
\mathrm{hr} / \mathrm{Btu}) \\
\text { Test }\end{array}$}} & \multirow{2}{*}{$\begin{array}{c}\text { Adjust. } \\
\text { End/Side } \\
\text { R-Value } \\
\text { Ratio } \\
(-)\end{array}$} \\
\hline & & & Side & Pipe & $\begin{array}{l}\text { Rating } \\
\text { Total }\end{array}$ & $\begin{array}{l}\text { Test } \\
\text { Rem. }\end{array}$ & $\begin{array}{l}\text { Ad } \\
\text { To }\end{array}$ & $\begin{array}{l}\text { d } \\
\text { Rem. }\end{array}$ & & & \\
\hline $\begin{array}{l}30 \\
40 \\
52 \\
82\end{array}$ & $\begin{array}{l}0.98 \\
0.97 \\
0.95 \\
0.91\end{array}$ & $\begin{array}{l}0.96^{\star} \\
0.95^{\star} \\
0.93^{\star} \\
0.91\end{array}$ & $\begin{array}{l}0.70 \\
0.93 \\
1.04 \\
1.27\end{array}$ & $\begin{array}{l}0.29 \\
0.29 \\
0.29\end{array}$ & $\begin{array}{l}0.48 \\
1.16 \\
2.19\end{array}$ & $\begin{array}{r}-0.53 \\
-0.16 \\
0.62\end{array}$ & $\begin{array}{l}1.14 \\
1.71 \\
2.19\end{array}$ & $\begin{array}{r}-0 . \\
0 . \\
0 .\end{array}$ & $\begin{array}{r}-4.0 \\
-4.0 \\
-17.5 \\
7.0\end{array}$ & $\begin{array}{r}-14.6 \\
-29.4 \\
7.2 \\
7.0\end{array}$ & $\begin{array}{r}-0.82 \\
-1.65 \\
0.40 \\
0.38\end{array}$ \\
\hline $\begin{array}{l}30 \\
40 s \\
40 \\
52 \\
66 \\
82\end{array}$ & $\begin{array}{l}0.94 \\
0.91 \\
0.93 \\
0.91 \\
0.89 \\
0.87\end{array}$ & $\begin{array}{l}0.93^{\star} \\
0.91 \\
0.91^{\star} \\
0.91 \\
0.89 \\
0.87\end{array}$ & $\begin{array}{l}0.70 \\
0.62 \\
0.93 \\
1.04 \\
1.15 \\
1.27\end{array}$ & $\begin{array}{l}0.49 \\
0.49 \\
0.49 \\
0.49 \\
0.49 \\
0.49\end{array}$ & $\begin{array}{l}1.41 \\
2.19 \\
1.66 \\
2.32 \\
2.73 \\
3.30\end{array}$ & $\begin{array}{l}0.22 \\
1.07 \\
0.25 \\
0.79 \\
1.09 \\
1.54\end{array}$ & $\begin{array}{l}2.19 \\
2.12 \\
2.32 \\
2.73\end{array}$ & $\begin{array}{l}1 . \\
0 . \\
0 . \\
1 . \\
1 .\end{array}$ & $\begin{array}{l}9.5 \\
4.1 \\
8.7 \\
3.5 \\
3.2 \\
2.8\end{array}$ & $\begin{array}{l}3.6 \\
4.1 \\
3.1 \\
3.5 \\
3.2 \\
2.8\end{array}$ & $\begin{array}{l}0.20 \\
0.22 \\
0.17 \\
0.19 \\
0.18 \\
0.15\end{array}$ \\
\hline $\begin{array}{l}30 s \\
30 \\
40 s \\
40 \\
52\end{array}$ & $\begin{array}{l}0.91 \\
0.93 \\
0.90 \\
0.92 \\
0.90\end{array}$ & $\begin{array}{l}0.91 \\
0.92^{\star} \\
0.90 \\
0.90^{\star} \\
0.90\end{array}$ & $\begin{array}{l}0.64 \\
0.84 \\
0.76 \\
1.13 \\
1.26\end{array}$ & $\begin{array}{l}0.49 \\
0.49 \\
0.49 \\
0.49 \\
0.49\end{array}$ & $\begin{array}{l}2.19 \\
1.66 \\
2.46 \\
1.92 \\
2.46\end{array}$ & $\begin{array}{l}1.05 \\
0.33 \\
1.20 \\
0.30 \\
0.70\end{array}$ & $\begin{array}{l}2.03 \\
2.46 \\
2.38\end{array}$ & $\begin{array}{l}0.70 \\
1.20 \\
0.76 \\
0.70\end{array}$ & $\begin{array}{l}3.4 \\
6.5 \\
3.6 \\
7.0 \\
4.0\end{array}$ & $\begin{array}{l}3.4 \\
3.1 \\
3.6 \\
2.8 \\
4.0\end{array}$ & $\begin{array}{l}0.22 \\
0.21 \\
0.24 \\
0.19 \\
0.27\end{array}$ \\
\hline $\begin{array}{l}30 \\
40 \\
50 \\
65 \\
80\end{array}$ & $\begin{array}{l}0.97 \\
0.96 \\
0.96 \\
0.95\end{array}$ & $\begin{array}{l}0.95^{\star} \\
0.94^{\star} \\
0.94^{\star} \\
0.92^{\star} \\
0.91^{\star}\end{array}$ & $\begin{array}{l}0.57 \\
0.66 \\
0.82 \\
0.94 \\
1.04\end{array}$ & $\begin{array}{l}0.29 \\
0.29 \\
0.29 \\
0.29 \\
0.29\end{array}$ & $\begin{array}{l}0.68 \\
0.92 \\
0.92 \\
1.16 \\
1.41\end{array}$ & $\begin{array}{r}-0.03 \\
-0.19 \\
-0.06 \\
0.08\end{array}$ & $\begin{array}{l}1.37 \\
1.46 \\
1.82 \\
2.19\end{array}$ & $\begin{array}{l}0.43 \\
0.34 \\
0.59 \\
0.87\end{array}$ & $\begin{array}{l}-12.8 \\
\star \star \star \star \star \star \star \\
-15.5 \\
-57.3 \\
55.0\end{array}$ & $\begin{array}{l}11.7 \\
6.9 \\
8.6 \\
6.3 \\
5.2\end{array}$ & $\begin{array}{l}0.33 \\
0.40 \\
0.29 \\
0.24\end{array}$ \\
\hline $\begin{array}{l}30 \\
40 \\
50 \\
65 \\
80\end{array}$ & $\begin{array}{l}0.92 \\
0.91 \\
0.90 \\
0.89 \\
0.88\end{array}$ & $\begin{array}{l}0.91^{\star} \\
0.91 \\
0.90 \\
0.89 \\
0.88\end{array}$ & $\begin{array}{l}0.82 \\
0.94 \\
1.18 \\
1.35 \\
1.49\end{array}$ & $\begin{array}{l}0.49 \\
0.49 \\
0.49 \\
0.49 \\
0.49\end{array}$ & $\begin{array}{l}1.92 \\
2.19 \\
2.46 \\
2.73 \\
3.01\end{array}$ & $\begin{array}{l}0.61 \\
0.75 \\
0.79 \\
0.89 \\
1.04\end{array}$ & $\begin{array}{l}2.30 \\
2.19 \\
2.46 \\
2.73 \\
3.01\end{array}$ & $\begin{array}{l}0.99 \\
0.75 \\
0.79 \\
0.89 \\
1.04\end{array}$ & $\begin{array}{l}3.7 \\
3.9 \\
3.8 \\
4.2 \\
4.4\end{array}$ & $\begin{array}{l}2.3 \\
3.9 \\
3.8 \\
4.2 \\
4.4\end{array}$ & $\begin{array}{l}0.16 \\
0.26 \\
0.25 \\
0.28 \\
0.29\end{array}$ \\
\hline $\begin{array}{r}30 \\
40 \\
50 \\
65 \\
80 \\
120\end{array}$ & $\begin{array}{l}0.91 \\
0.91 \\
0.88 \\
0.88 \\
0.87\end{array}$ & $\begin{array}{l}0.91 \\
0.91 \\
0.88 \\
0.88 \\
0.87\end{array}$ & $\begin{array}{l}0.99 \\
1.13 \\
1.42 \\
1.61 \\
1.77 \\
2.25\end{array}$ & $\begin{array}{l}0.49 \\
0.49 \\
0.49 \\
0.49 \\
0.49\end{array}$ & $\begin{array}{l}2.19 \\
2.19 \\
3.01 \\
3.01 \\
3.30 \\
4.85\end{array}$ & $\begin{array}{l}0.70 \\
0.56 \\
1.10 \\
0.91 \\
1.04 \\
2.11\end{array}$ & $\begin{array}{l}2.19 \\
2.19 \\
3.01 \\
3.01 \\
3.30 \\
4.85\end{array}$ & $\begin{array}{l}0.70 \\
0.56 \\
1.10 \\
0.91 \\
1.04 \\
2.11\end{array}$ & $\begin{array}{l}2.8 \\
4.7 \\
2.4 \\
3.7 \\
4.0 \\
2.7\end{array}$ & $\begin{array}{l}2.8 \\
4.7 \\
2.4 \\
3.7 \\
4.0 \\
2.7\end{array}$ & $\begin{array}{l}0.22 \\
0.36 \\
0.18 \\
0.28 \\
0.30 \\
0.20\end{array}$ \\
\hline
\end{tabular}


TABLE G-3 (continued)

\begin{tabular}{|c|c|c|c|c|c|c|c|c|c|c|c|}
\hline \multirow[b]{2}{*}{$\begin{array}{l}\text { Size } \\
\text { (gal) }\end{array}$} & \multirow[b]{2}{*}{$\begin{array}{l}E F \\
(-)\end{array}$} & \multirow{2}{*}{$\begin{array}{c}\text { Adj. } \\
E F \\
(-)\end{array}$} & \multicolumn{6}{|c|}{ Heat Loss Coef. (Btu/hr- $\left.{ }^{\circ} \mathrm{F}\right)$} & \multicolumn{2}{|c|}{$\begin{array}{l}\text { End } \\
R-V a l \text { ue }\end{array}$} & \multirow{2}{*}{$\begin{array}{l}\text { Adjust. } \\
\text { End/Side } \\
\text { R-Value } \\
\text { Ratio } \\
(-)\end{array}$} \\
\hline & & & Side & Pipe & $\begin{array}{l}\text { Rating } \\
\text { Total }\end{array}$ & $\begin{array}{l}\text { Test } \\
\text { Rem. }\end{array}$ & $\begin{array}{l}\text { Adjust } \\
\text { Total }\end{array}$ & $\begin{array}{l}\text { ed } \\
\text { Rem. }\end{array}$ & $\begin{array}{l}\mathrm{hr} / \\
\text { Test }\end{array}$ & $\begin{array}{l}\text { tu) } \\
\text { Adj. }\end{array}$ & \\
\hline $\begin{array}{l}50 \mathrm{~m} \\
20 \mathrm{~s} \\
30 \mathrm{~s} \\
40 \mathrm{~s} \\
47 \mathrm{~s} \\
50 \mathrm{~s}\end{array}$ & $\begin{array}{l}0.90 \\
0.94 \\
0.91 \\
0.91 \\
0.91 \\
0.89\end{array}$ & $\begin{array}{l}0.90 \\
0.93^{\star} \\
0.91 \\
0.91 \\
0.91 \\
0.89\end{array}$ & $\begin{array}{l}1.24 \\
0.62 \\
0.71 \\
0.85 \\
0.88 \\
1.10\end{array}$ & $\begin{array}{l}0.49 \\
0.49 \\
0.49 \\
0.49 \\
0.49 \\
0.49\end{array}$ & $\begin{array}{l}2.46 \\
1.41 \\
2.19 \\
2.19 \\
2.19 \\
2.73\end{array}$ & $\begin{array}{l}0.72 \\
0.30 \\
0.98 \\
0.85 \\
0.81 \\
1.14\end{array}$ & $\begin{array}{l}2.46 \\
1.70 \\
2.19 \\
2.19 \\
2.19 \\
2.73\end{array}$ & $\begin{array}{l}0.72 \\
0.58 \\
0.98 \\
0.85 \\
0.81 \\
1.14\end{array}$ & $\begin{array}{l}4.6 \\
7.5 \\
3.7 \\
5.3 \\
6.9 \\
3.7\end{array}$ & $\begin{array}{l}4.6 \\
3.8 \\
3.7 \\
5.3 \\
6.9 \\
3.7\end{array}$ & $\begin{array}{l}0.35 \\
0.29 \\
0.28 \\
0.39 \\
0.51 \\
0.27\end{array}$ \\
\hline
\end{tabular}

* Value adjusted for maximum possible test error range. 
TABLE G-4

Rating Test Error Range

\begin{tabular}{|c|c|c|c|c|c|}
\hline $\begin{array}{l}\text { Size } \\
\text { (gal) }\end{array}$ & $\begin{array}{l}E F \\
(-)\end{array}$ & $\begin{array}{l}\begin{array}{r}\text { Rati } \\
\text { Hea }\end{array} \\
\text { (Btu/ } \\
\text { of-hr) }\end{array}$ & $\begin{array}{l}\text { g Test } \\
\text { Loss } \\
\text { (Btu/ } \\
\text { of-day) }\end{array}$ & $\begin{array}{c}\text { Test } \\
\text { Cycles, } \\
48 \mathrm{hr} . \\
4^{\circ} \mathrm{F} \\
\text { Deadband } \\
(-)\end{array}$ & $\begin{array}{l}\text { Maximimum } \\
\text { Error, } \\
\text { Fraction } \\
\qquad(-)\end{array}$ \\
\hline $\begin{array}{l}30 \\
40 \\
52 \\
82\end{array}$ & $\begin{array}{l}0.98 \\
0.97 \\
0.95 \\
0.91\end{array}$ & $\begin{array}{l}0.45 \\
0.68 \\
1.16 \\
2.19\end{array}$ & $\begin{array}{l}4.37 \\
4.97 \\
6.51 \\
7.76\end{array}$ & $\begin{array}{l}2.19 \\
2.49 \\
3.25 \\
3.88\end{array}$ & $\begin{array}{l}0.46 \\
0.40 \\
0.31 \\
0.26\end{array}$ \\
\hline $\begin{array}{l}30 \\
40 s \\
40 \\
52 \\
66 \\
82\end{array}$ & $\begin{array}{l}0.94 \\
0.91 \\
0.93 \\
0.91 \\
0.89 \\
0.87\end{array}$ & $\begin{array}{l}1.41 \\
2.19 \\
1.66 \\
2.32 \\
2.73 \\
3.30\end{array}$ & $\begin{array}{l}13.68 \\
15.90 \\
12.10 \\
12.98 \\
12.04 \\
11.72\end{array}$ & $\begin{array}{l}6.84 \\
7.95 \\
6.05 \\
6.49 \\
6.02 \\
5.86\end{array}$ & $\begin{array}{l}0.15 \\
0.13 \\
0.17 \\
0.15 \\
0.17 \\
0.17\end{array}$ \\
\hline $\begin{array}{l}30 s \\
30 \\
40 s \\
40 \\
52\end{array}$ & $\begin{array}{l}0.91 \\
0.93 \\
0.90 \\
0.92 \\
0.90\end{array}$ & $\begin{array}{l}2.19 \\
1.66 \\
2.46 \\
1.92 \\
2.46\end{array}$ & $\begin{array}{l}21.20 \\
16.13 \\
17.86 \\
13.98 \\
13.74\end{array}$ & $\begin{array}{r}10.60 \\
2.07 \\
8.93 \\
6.99 \\
6.87\end{array}$ & $\begin{array}{l}0.09 \\
0.12 \\
0.11 \\
0.14 \\
0.15\end{array}$ \\
\hline $\begin{array}{l}30 \\
40 \\
50 \\
65 \\
80\end{array}$ & $\begin{array}{l}0.97 \\
0.96 \\
0.96 \\
0.95 \\
0.94\end{array}$ & $\begin{array}{l}0.68 \\
0.92 \\
0.92 \\
1.16 \\
1.41\end{array}$ & $\begin{array}{l}6.63 \\
6.70 \\
5.36 \\
5.21 \\
5.13\end{array}$ & $\begin{array}{l}3.31 \\
3.35 \\
2.68 \\
2.60 \\
2.57\end{array}$ & $\begin{array}{l}0.30 \\
0.30 \\
0.37 \\
0.38 \\
0.39\end{array}$ \\
\hline $\begin{array}{l}30 \\
40 \\
50 \\
65 \\
80\end{array}$ & $\begin{array}{l}0.92 \\
0.91 \\
0.90 \\
0.89 \\
0.88\end{array}$ & $\begin{array}{l}1.92 \\
2.19 \\
2.46 \\
2.73 \\
3.01\end{array}$ & $\begin{array}{l}18.64 \\
15.90 \\
14.29 \\
12.23 \\
10.96\end{array}$ & $\begin{array}{l}9.32 \\
7.95 \\
7.14 \\
6.11 \\
5.48\end{array}$ & $\begin{array}{l}0.11 \\
0.13 \\
0.14 \\
0.16 \\
0.18\end{array}$ \\
\hline $\begin{array}{c}30 \\
40 \\
50 \\
65 \\
80 \\
120 \\
50 \mathrm{~m}\end{array}$ & $\begin{array}{l}0.91 \\
0.91 \\
0.88 \\
0.88 \\
0.87 \\
0.82 \\
0.90\end{array}$ & $\begin{array}{l}2.19 \\
2.19 \\
3.01 \\
3.01 \\
3.30 \\
4.85 \\
2.46\end{array}$ & $\begin{array}{l}21.20 \\
15.90 \\
17.54 \\
13.49 \\
12.01 \\
11.76 \\
14.29\end{array}$ & $\begin{array}{r}10.60 \\
7.95 \\
8.77 \\
6.74 \\
6.01 \\
5.88 \\
7.14\end{array}$ & $\begin{array}{l}0.09 \\
0.13 \\
0.11 \\
0.15 \\
0.17 \\
0.17 \\
0.14\end{array}$ \\
\hline
\end{tabular}


TABLE G-4 (continued)

\begin{tabular}{|c|c|c|c|c|c|}
\hline $\begin{array}{l}\text { Size } \\
\text { (gal) }\end{array}$ & $\begin{array}{l}E F \\
(-)\end{array}$ & $\begin{array}{l}\text { Rati } \\
\frac{\text { Hea }}{\text { (Btu/ }} \\
\text { of-hr) }\end{array}$ & $\begin{array}{l}\text { g Test } \\
\text { Loss } \\
\text { (Btu/ } \\
\text { of-day) }\end{array}$ & $\begin{array}{c}\text { Test } \\
\text { Cycles, } \\
48 \mathrm{hr} \text {. } \\
4^{\circ} \mathrm{F} \\
\text { Deadband } \\
(-)\end{array}$ & $\begin{array}{l}\text { Maximimum } \\
\text { Error, } \\
\text { Fraction } \\
\quad(-)\end{array}$ \\
\hline $\begin{array}{l}20 s \\
30 s \\
40 s \\
47 s \\
50 s\end{array}$ & $\begin{array}{l}0.94 \\
0.91 \\
0.91 \\
0.91 \\
0.89\end{array}$ & $\begin{array}{l}1.41 \\
2.19 \\
2.19 \\
2.19 \\
2.73\end{array}$ & $\begin{array}{l}20.52 \\
21.20 \\
15.90 \\
13.53 \\
15.89\end{array}$ & $\begin{array}{r}10.26 \\
10.60 \\
7.95 \\
6.77 \\
7.95\end{array}$ & $\begin{array}{l}0.10 \\
0.09 \\
0.13 \\
0.15 \\
0.13\end{array}$ \\
\hline
\end{tabular}


TABLE G-5

Sample Averages

\begin{tabular}{rccccccc}
\hline Tank \\
$\begin{array}{c}\text { Size } \\
\text { (gal) }\end{array}$ & $\begin{array}{c}\text { Size Range } \\
\text { Mini) }\end{array}$ & $\begin{array}{c}\text { Max. } \\
\text { (gai) }\end{array}$ & $\begin{array}{c}\text { No. } \\
\text { Tanks } \\
\text { Avgd. } \\
(-)\end{array}$ & $\begin{array}{c}\text { Surface } \\
\text { Nolume } \\
\text { Ratio } \\
(-)\end{array}$ & $\begin{array}{c}\text { End/Total } \\
\text { Surface } \\
\text { Area Ratio } \\
(-)\end{array}$ & $\begin{array}{c}\text { End/Side } \\
\text { R-Value } \\
\text { Ratio } \\
(-)\end{array}$ & $\begin{array}{c}\text { Gross/Net } \\
\text { Diameter } \\
\text { Ratio } \\
(-)\end{array}$ \\
\hline 30 & 0 & 35 & 9 & 0.53 & 0.18 & - & - \\
40 & 35 & 45 & 9 & 0.48 & 0.19 & - & - \\
50 & 45 & 57 & 9 & 0.45 & 0.17 & - & - \\
65 & 57 & 73 & 4 & 0.42 & 0.15 & - & - \\
82 & 73 & 100 & 5 & 0.38 & 0.16 & - & - \\
120 & 100 & $100+$ & 1 & 0.33 & 0.16 & - & - \\
A11 & - & - & 37 & - & 0.17 & 0.28 & 0.80
\end{tabular}


Appendix $\mathrm{H}$

CONSERVATION MEASURE IMPACTS DERIVED FROM THE

BONNEVILLE TEST DATA OF EK AND AUBERG (1984) 


\section{Appendix $\mathrm{H}$}

Conservation Measure Impacts Derived from the Bonneville Test Data of Ek and Auberg (1984)

The energy savings results for each 1aboratory test of Ek and Auberg (1984), reported in Table II of their paper, is reproduced in Table H-1. These data resulted from laboratory tests of water heater standby loads over a period of several days, each test providing the electricity consumed by the tank to maintain its thermostat set temperature. Water pipes were provided to simulate heat losses from overhead horizontal piping runs (for a tank in a home's basement) or torizontal piping below tank level (for a tank in a closet and piping in a crawlspace). Two tanks were used in the tests, a typical standard tank and an energy efficient model from 1983.

The savings estimates in the table are the difference between consumption by the basic water heater with no conservation measures and no plumbing attached and the consumption of the same water heater under the conditions indicated in the table. Note that in many cases more than one test was conducted, sometimes with largely varying results. Undoubtedly one source of this variance is the fact that the savings are obtained from subtracting two measured loads that are nearly equal; that is, the effect of these measures is often small relative to the measured loads, so the difference between the measured loads is small and magnifies any uncertainties in the basic load measurements or test conditions. This is supported by the much better consistency of the tank wrap savings, which are larger in magnitude relative to the measured loads.

Nevertheless, these tests have provided a much needed benchmark and are a key source of assumptions about impacts of conservation measures in the region. Bonneville staff are currently engaged in repeating and updating this series of tests with currently available tanks. 
Table H-1

Savings Data from Table II of Ek and Auberg (1984)

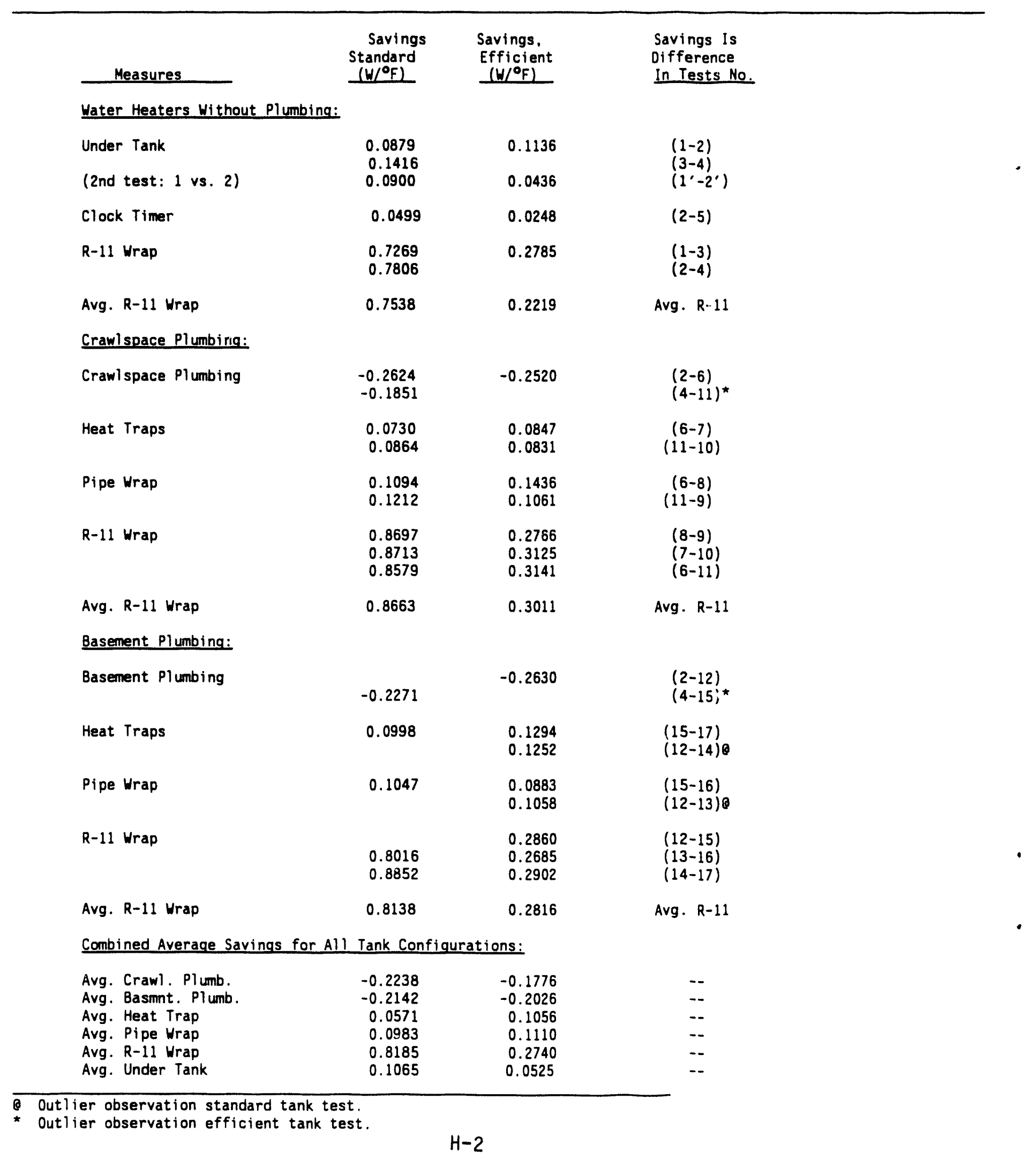


These data were examined for the analysis that is the subject of this report, for use in estimating nominal tank $R$-values from the effective $R$ values. In this process, estimates of pipe losses and the impact of measures installed in the ELCAP homes on the tank heat loss rates were subtracted from the effective R-values estimated previously. One particularly puzziing implication of the data in Table $\mathrm{H.l}$ is highlighted by the Combined Average Savings for All Tank Conirigurations at the boiton of the table. This suggests that the average savings resulting from use of heat traps is almost twice as large for the efficient tank as for the standard tank. Because the pipe heat loss is, in principle, parallel with the losses through the tank walls, it should be independent of the tank insulation level. A possible explanation for this has been developed and is reported here.

Hypothesizing that the effects of plumbing heat loss and associated conservation measures (pipe wraps and heat traps) should be independent of the type of tank involved, it is immediately possible to flag savings estimates that are outliers from among the four savings estimates for each type of measure. The outlier data has been marked with an "@" for standard tanks or an $n * "$ for efficient tanks. The fourth column in the table shows the two test configurations whose loads were subtracted to obtain the savings estimate, also marked sinilarly.

It is immediately obvious that efficiomt tank test 4 and standard tank test 12 are the only tests involved in all ine outlier savings estimates. If these two tests are assumed to have much larger than typical errors, it can be seen that efficient tank test 4 is also involved in two other of the largest inconsistencies in the table (under-tank insulation and R-11 wraps without plumbing); further supporting the hypothesis. If 111 savings estimates derived from these two tests are eliminated from the combined average summary at the bottom of the table, the combined average's would become as shown in Table H-2. The average heat trap savings estimates are now much closer for the two types of tanks, and the pipe wrap estimates are almost identical. The basic pipe loss estinates for the crawispace plumbing configuration are now larger than for the basement configuration, and the under-tank insulation. (bottom board) savings estimate is significantly larger for efficient tanks. 
While these observations and logic are not conclusive, the circumstantial evidence is considered large enough so that the adjusted data in Table H-2. are used in the analysis described in this report and recommended to others for their consideration until updated test results are available.

\section{Table $\mathrm{H}-2$}

Savings Data from Table II of Ek and Auberg (1984) Eliminating Outlier Tests (Efficient Tank Test 4 and Standard Tank Test 12)

\begin{tabular}{|c|c|c|c|}
\hline Measures & $\begin{array}{c}\text { Savings, } \\
\text { Standard } \\
(W / \circ F)\end{array}$ & $\begin{array}{l}\text { Savings, } \\
\text { Efficient } \\
(W / \circ F) \\
\end{array}$ & $\begin{array}{c}\text { Savings, } \\
\text { Both } \\
(W / \circ F) \\
\end{array}$ \\
\hline \multicolumn{4}{|c|}{ Combined Average Savings for All Tank Configurations: } \\
\hline $\begin{array}{l}\text { Avg. Crawl. Plumb. } \\
\text { Avg. Basmnt. Plumb. } \\
\text { Avg. Heat Trap } \\
\text { Avg. Pipe Wrap } \\
\text { Avg. R-11 Wrap } \\
\text { Avg. Under Tank }\end{array}$ & $\begin{array}{r}-0.2238 \\
-0.2271 \\
0.0867 \\
0.1118 \\
0.8276 \\
0.1065\end{array}$ & $\begin{array}{r}-0.2520 \\
-0.2630 \\
0.1056 \\
0.1110 \\
0.2740 \\
0.0786\end{array}$ & $\begin{array}{l}-0.2379 \\
-0.2451 \\
0.0960 \\
0.1114 \\
-- \\
--\end{array}$ \\
\hline
\end{tabular}




\section{DISTRIBUTION}

No. of

Copies

\section{OFFSITE}

2 DOE/Office of Scientific and Technical Information

2 M. E. Miller Bonneville Power Administration End-Use Research Section P.0. Box 3621-RPEE Portland, OR 97208

J. Cahill Bonneville Power Administration End-Use Research Section P.0. BoX 3621-RPEE Portland, OR 97208
No. of

Copies

2 W. M. Warwick Battelle Portland Office 500 NE Multnomah, Suite 650

Portland, OR 97232

T. J. Foley

Battelle Portland Office 500 NE Multnomah, Suite 650

Portland, OR 97232

\section{ONSITE}

12 Pacific Northwest Laboratory

R. G. Pratt

W. F. Sandusky (5)

Publishing Coordination

Technical Report Files (5) 

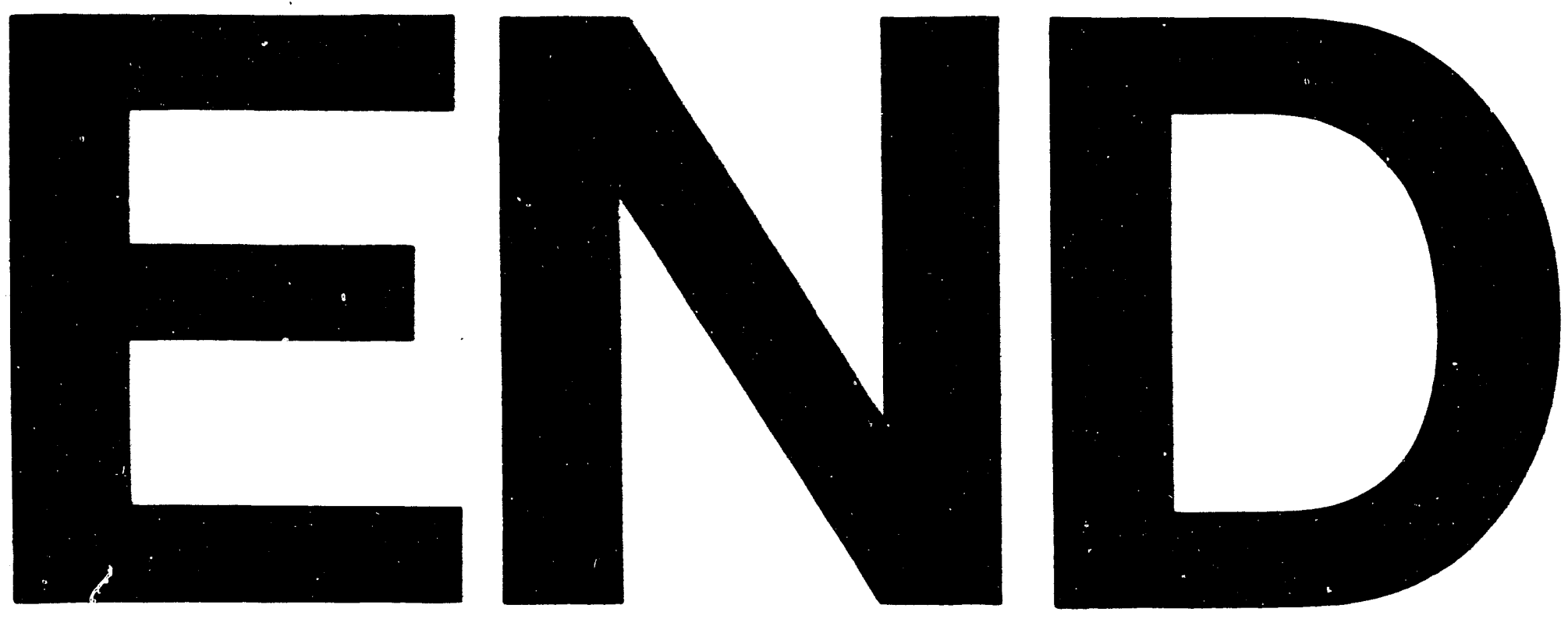

$f$
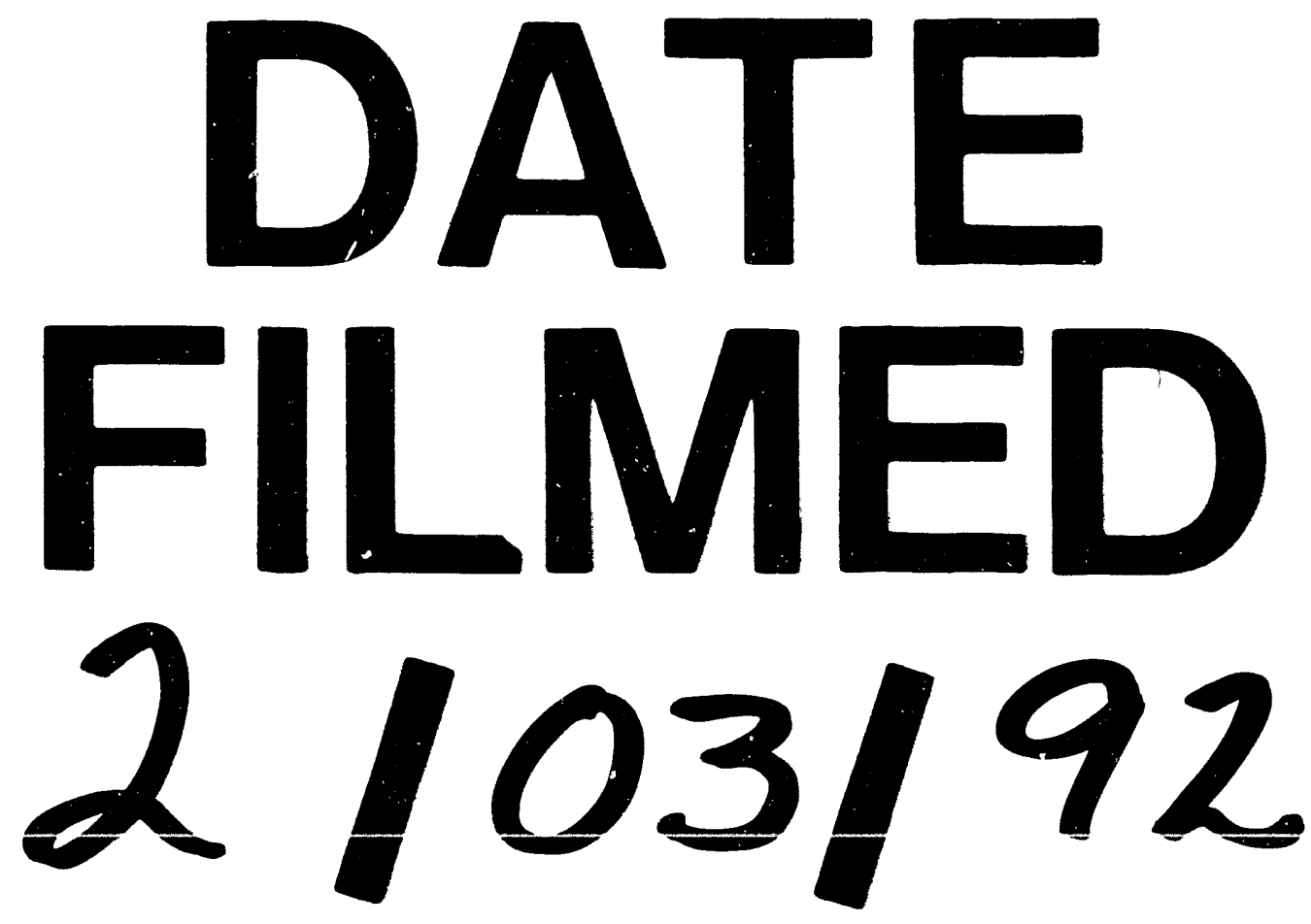
